\title{
Cristianismo e Espaço Público: aspectos políticos e sociais
}

\section{A configuração do cenário social e religioso do distrito de Ponte do Cosme: um estudo sobre tradição e memória.}

The configuration of the social and religious scenery of Ponte do Cosme district: a study of tradition and memory.

\author{
Vitor Cesar Presoti ${ }^{1}$ \\ vitorcpresoti@gmail.com
}

Reinaldo Azevedo Schiavo ${ }^{2}$ reinaldomatipo@yahoo.com.br

Resumo: O objetivo, nesse artigo, é apresentar alguns resultados preliminares da pesquisa, ainda em andamento, sobre a configuração social e religiosa de Ponte do Cosme, um distrito da cidade de Barbacena-MG fundado por imigrantes italianos no início do século XX. A peculiaridade local foi inicialmente detectada em seu campo religioso, onde encontramos uma população divida entre católicos e espíritas ${ }^{3}$, sem nenhuma presença de evangélicos ou religiões de matriz africana. Utilizando a memória social como fonte de pesquisa e adotando métodos qualitativos de investigação científica, buscamos identificar e analisar as relações de poder e a posição que indivíduos singulares e grupos familiares ocupam nesse espaço social, com o intuito de compreender os sentidos, as condições e as estratégias que possibilitam a preservação de um cenário bucólico, politicamente conservador e tradicionalmente religioso.

Palavras-chaves: Espiritismo, Catolicismo, Memória, Configuração Social, Modernidade.

${ }^{1}$ Graduando em Ciências Sociais pelaUniversidade do Estado de Minas Gerais (UEMG).

${ }^{2}$ Mestre em História pela (UFOP), Doutorando em Sociologia (IUPERJ), professor do curso de Ciências Sociais da Universidade do Estado de Minas Gerais (UEMG).

${ }^{3}$ No decorrer deste trabalho, ao nos referimos aos termos espírita e espiritismo, estaremos sempre o utilizando para designar a doutrina inicialmente criada por Hippolyte Léon DenizadRivali, o espiritismo Kardecista. 
Abstratic: The purpose of this article is to present some preliminary results of the ongoing research on the social and religious configuration of Ponte do Cosme, a district of the city of Barbacena-MG founded by Italian immigrants in the early 20th century. The local peculiarity was initially detected in its religious field, where we find a population divided between Catholics and Spiritists, with no presence of evangelicals or religions of African matrix. Using social memory as a source of research and adopting qualitative methods of scientific investigation, we seek to identify and analyze the relations of power and the position that individuals and family groups occupy in this social space, with the purpose of understanding the meanings, conditions and strategies that allow the preservation of a bucolic, politically conservative and traditionally religious setting.

Key-words: Spiritism, Catholicism, Memory, Social Configuration, Modernity.

...relacionar religião e sociedade, comportamento religioso e teoria social, enfim, tudo dentro de um esforço honesto de compreender a sociedade moderna e dar a tal compreensão caráter científico, desenvolvimento lógico e argumentação racional.

Breno Martins Campos

\section{Introdução}

No mundo moderno e globalizado, a religião continua exercendo grande influência pública, estabelecendo laços sociais entre indivíduos, determinando normas de conduta e preceitos morais, legitimando e/ou deslegitimando ações coletivas e definindo pautas de debates políticos na ágora. Em suma, as organizações sociais e políticas das sociedades não estão isentas das influências do campo religioso, pois a religião está diretamente relacionada à ordenação do mundo, contribuindo para a imposição dissimulada dos princípios de estruturação da percepção e forma de pensamento do mundo "e, em particular, do mundo social, na medida em que impõe um sistema de práticas e de representações cuja estrutura objetivamente fundada em um princípio da divisão política apresenta-se como a estrutura natural-sobrenatural do cosmos" (Bourdieu, 2005, pp. 33-34).

Como afirmou Clifford Geertz (2008, p. 67), “a religião ajusta as ações humanas a uma ordem cósmica imaginada e projeta imagens da ordem cósmica no plano da experiência humana", por isso é uma importante chave de leitura das sociedades em seus diversos 
contextos históricos. O politeísmo greco-romano é fundamental para explicação e compreensão da chamada antiguidade clássica. O mesmo acontece com o mundo medieval e sua organização social tripartite: trabalho, guerra e religião (laboratores, bellatores $e$ oratores); o medievohistórico só existe em par com a religião (Duby, 1994). Da mesma forma, é impossível entender o Oriente Médio sem o Islã, a Índia sem o hinduísmo ou a colonização da América sem o cristianismo. Em todos os espaços e tempos, a religião esteve e está intimamente vinculada à sociedade, estabelecendo laços sociais entre indivíduos, determinando normas de conduta e preceitos morais e influenciando significativamente as dimensões da vida individual e social. Entendemos, então, que o estudo acerca da religião, a fim de realizarmos uma reflexão aprofundada sobre a dinâmica de sua estrutura, visualizar as disputas pelo poder e bens simbólicos e de criação de identidade social, política e religiosa, se torna indispensável para o entendimento da organização e estruturação das sociedades.

Este artigo é fruto de uma pesquisa ainda em andamento em que, através do recorte do campo religioso, analisamos a configuração social de Ponte do Cosme, um distrito da cidade de Barbacena - MG, fundado por imigrantes italianos no início do século XX, o qual possui uma configuração social e religiosa muito particular, distinta da realidade observada no restante da cidade. A análise da sociogênese do distrito tornou-se foco do nosso interesse ao percebermos uma forte ligação entre a doutrina espírita Kardecista e as colônias de imigrantes italianos de Barbacena. A inquietação partiu do olhar sobre experiências cotidianas de indivíduos singulares destedistrito, de forma que pudemos notar que assuntos relacionados ao espiritismo surgiam com muita frequência dentro da teia social dos grupos de descendentes dos imigrantes.

Buscamos identificar e analisar as características do campo religioso e social de Ponte do Cosme, suas peculiaridades, tradições, estrutura e conflitos, verificar as posições que os indivíduos e os grupos familiares ocupam e exercem no espaço social do distrito e do município de Barbacena. Enfatizando a interpretação do papeis desempenhados pelos espíritas no campo religioso, acessandoos elementos históricos e sociológicos que propiciam a manutenção de uma configuração religiosa tão peculiar. Por fim, buscamos analisar a postura que a sociedade local adota frente à lógica de organização do mundo moderno, no intuito de compreender os sentidos, as condições e as estratégias que possibilitam a preservação de um cenário bucólico, politicamente conservador e tradicionalmente religioso.

Utilizando a metodologia da história oral e realizando entrevistas semiestruturadas, priorizamos a memória social e coletiva como fonte de pesquisa, entendendo que as memórias que os grupos religiosos tendem a preservar e perpetuarrevelam as peculiaridades daquela 
configuração social. A memória coletiva (Halbwachs, 1990) é estabelecida a partir de uma combinação de lembranças e esquecimentos que acomodam, de certa forma, uma autoimagem que os grupos sociais fazem de si próprios, denunciando como os atores sociais e as instituições se identificam e se arranjam na história, pois a memória:

[...] é uma reconstrução psíquica e intelectual que acarreta de fato uma representação seletiva do passado, um passado que nunca é aquele do indivíduo somente, mas de um indivíduo inserido num contexto familiar, social, nacional. Portanto toda memória é, por definição, coletiva (Rousso, 2002, p. 94).

A memória coletiva é um instrumento fundamental para realizar uma conexão entre o passado e presente, nela o passado mantém sua estiva com o ocorrido, sendo dotada de novos sentidos a cada lembrança, a cada ressignificação.Além disso, a transmissão dos saberes produzidos por uma coletividade, aquilo que Mannheim (1982) chamou de "herança cultural", encontra na memória uma de suas mais influentes vias.A forma figuracional que os agrupamentos humanos adquirem é, sempre, resultado de processos sócio-históricos que tem a memória como elemento de conexão entre diferentes gerações.

É válido salientar que nossa pesquisa tem como objetivo compreender o tipo de figuração existente em Ponte do Cosme, priorizando a memória coletiva e tomando a religião como um dos elementos determinantes da configuração social. Não é nosso intuito questionar a validade da fé, mas entender em que medida a prática religiosa no distrito produz efeitos e influi na vida dos indivíduos e na organização do grupo social, a fim de retornar aos homens os sentidos de suas ações.

\section{O Distrito}

Ponte do Cosme é uma comunidade rural que conta com um centro espirita e uma igreja católica, é predominantemente formado por descendentes de imigrantes italianos que, a priori, foram alocados na Colônia Rodrigo Silva, que até então pertencia ao distrito de Antônio Carlos - MG (hoje faz parte do território de Barbacena-MG), de lá os imigrantes irradiaram para outras localidades, principalmente territórios rurais. Algumas destas famílias como os Zílli, os Bertolla e os Mazonni, foram as pioneiras do distrito, instalando-se na localidade por volta de 1908 conforme relatos nas entrevistas:

Entrevistado: A Colônia Rodrigo Silva se estendia desde lá, a Colônia atual, né, onde nós conhecemos como Rodrigo Silva, até próximo a Sá Fortes aqui, era tudo Colônia Rodrigo Silva. Depois com o tempo, vários setores foram tornando nomes e 
locais, né?! Então, aqui foi Ponte do Cosme; ali próximo ao Ceolim existia o grupo família Viol, né?! O próprio Ceolim deu nome àquela localidade ali, é... E outros lugares, que foram recebendo nomes assim, localizados, né?!

A pesquisa revelou o mito do Seu Cosme, um morador simples que por acaso deu nome ao distrito, este senhor residia próximo à ponte que foi construída sobre o rio das mortes e, segundo os entrevistados, esta se tornou a referência da localidade, as pessoas diziam que estavam indo à ponte... à "Ponte do Cosme", sendo elevado a distrito em 1999, quando tinha 909 habitantes segundo o Censo de 2000.

Particularmente, em Ponte do Cosme há certa paridade entre a quantidade de espíritas e católicos dentro da sociedade local, fato que chama muita atenção, visto que Barbacena é uma cidade majoritariamente católica. Conforme os dados do último censo (2010), 86,95\% dos seus 126.284 habitantes se declararam católicos, números bem acima dos 64,6\% da média nacional. Em contrapartida, 7,44\% dos recenseados se declaram evangélicos, um percentual pequeno comparado à média de $22,2 \%$ para todo o país. Soma-se aos dados $1,83 \%$ de espíritas, 2,24\% de pessoas sem religião e 1,54\% para a soma de outras religiões (Testemunha de Jeová, Matriz Africana, Orientais, esotéricas e religião não determinada). Outro dado que a pesquisa revela é que não existe nenhuma outra organização religiosa dentro do distrito, apenas espíritas e católicos, sendo que segundos levantamentos da pesquisa, a população do distrito praticamente se divide em números muitos próximo entre os dois segmentos.

O fato da organização religiosa de Ponte do Cosme permitir uma dissonância tão significativa quanto ao arranjo religioso do município é uma das principais motivações para uma análise mais aprofundada do contexto religioso e social do distrito, sendoo principal estímulo para a pesquisa sociológica do elemento da religião na comunidade local e a análise dos impactos nos arranjos da vida do grupo social.

Ponte do Cosme apresenta algumas características de uma comunidade relativamente corporada, segundo o modelo proposto por Wolf (2003). Segundo o autor, a comunidade corporada possui uma lógica social demarcada, bem delineada, uma identidade estrutural que delimita tanto os deveres como os direitos de seus membros, gerando assim uma ética, um modelo de comportamento, que vista de fora, sustenta uma série de atividades que mantém suas representações coletivas. O sistema de poder é intimamente atrelado a uma lógica religiosa, demarcando-o como um sistema político-religioso qual abarca os homens e delimita as fronteiras da comunidade, possuem também certos mecanismos de nivelação para a manutenção da comunidade corporada, de forma que as divisões de classes se adequem aos limites da comunidade. Atributos culturais, sociais e linguísticos, produzidos através de 
organizações plurais, têm por finalidade a manutenção da integridade comunitária validando sua atuação de negativa consciente das formar comportamentais divergentes covariantes. É uma comunidade composta especialmente por uma única subcultura, o campesinato, desaprovando a acumulação e exibição de riqueza individual e estimula o equilíbrio tradicional, evitando as oscilações das relações.

Podemos classificar o distrito de Ponte do Cosmecomo uma comunidade relativamente corporada, pois possui uma forte lógica de organização a partir da religião, demarcando e criando as identidades dos indivíduos e dos grupos. São bastante fechados quanto à entrada de moradores que não possuam nenhum parentesco com os grupos locais. Possuem uma lógica de distribuição do espaço baseada no parentesco, com os pais cedendo uma parcela do terreno aos filhos para construírem suas casas. Resistem de certa forma as influências vindas de fora de seus limites, mantendo seus atributos culturais e sociais organizados por fatores de dentro de suas fronteiras, sendo perpetuados através das gerações por mais de cem anos, mantendo assim uma lógica de organização com base nos laços de parentescos, lançando seus membros em posições sistemáticas e participavas quanto a assuntos religiosos e políticos, em grande parte através da organização a partir do elemento da religião ao mesmo tempo em que adentram e remodelam este elemento.

A economia do distrito, a princípio, era movida pela agricultura através de tecnologias tradicionais quais envolviam continuamente quase todos os membros da comunidade em um trabalho braçal. Estas características acabaram por limitar a capacidade de produção de excedentes para o mercado externo, oque acaba por reduzir o transito de bens vindos de fora para o consumo da comunidade, o que inevitavelmente inseriu o distrito em uma dinâmica de mercado muito pobre, frente à lógica de agricultura mecanizada e aos grandes latifundiários. Em vista destas dificuldades os moradores do distrito movimentam suas economias na área urbana de Barbacena, prestando serviço no comércio como assalariados, com algum negócio próprio ou como servidores públicos, a agricultura acabou reduzida a uma ou outra família que persistes abastecendo pequenos mercados, e aos cultivos para consumo próprio.

Muitas destas famílias que encontraram na localidade o seu lar, ali permanecem, hoje já na quarta ou quinta geração, dando continuidade aos arranjos iniciados pelos primeiros imigrantes que ali se instalaram, e foi a partir de uma destas famílias pioneiras que se iniciam as atividades da doutrina espírita dentro da comunidade. 


\title{
A Doutrina Espírita Kardecista
}

\begin{abstract}
Muito antes do surgimento das religiões organizadas, o homem já acreditava em espíritos [...] desde cedo julgou-se que todos os seres e coisas [...] estariam dotados de um espírito, que seria, sua parte imaterial, sua essência, seu princípio vital, sua força invisível, sua dimensão não perecível - são muitas as definições e concepções possíveis -, em fim: sua alma(Prandi, 2012, p. 7)
\end{abstract}

Em 1857, Allan Kardeck, publicou na França O livro dos espíritos, a obra que marca o início do pensamento espírita e distingue de fato a doutrina do movimento espiritualista. Conforme a proposta de Kardeck, "o codificador" como também é conhecido, o espiritismo se expressa não somente como religião, mas também como filosofia e ciência, baseando-se na comunicação com os espíritos desencarnados e a crença na reencarnação. Castro $(1985$, p. 3$)$ pontua que "essa definição dos espíritas nos conduz a uma das características distintivas do Espiritismo, e nos reconduz à questão dos diferentes ângulos possíveis de visão de um fato, a princípio, mesmo", e continua a autora:

[...] Assim como a visão de alguma coisa depende do lugar em que nos situamos ao olhá-la, a sua definição é função do ponto de vista sob o qual a encaramos. Um mesmo fenômeno pode ser vivido, pensado e compreendido de modo muito diverso em função de quem o viva, pense e compreenda. Para um espírita, o Espiritismo terá um sentido. Para um católico, um ateu, um umbandista, um psicólogo ou um antropólogo, outros.(Castro, 1985, p. 3)

A crença na reencarnação pode ser identificada como uma das mais notáveis características em que se fundamenta a doutrina espírita. Sendo entendida como a volta do espírito desencarnado a vida corpórea, a volta da alma ao plano físico em um novo corpo material especificamente preparado para este momento contextual, um processo que pode se repetir por diversas vezes. Diante o espiritismo, a alma não pode retroceder em seu processo evolutivo, em contra partida é possível estacionar, mas segundo a doutrina, não há o retrocesso do espírito. Assim sendo, a reencarnação é o processo das existências contínuas, retomando o espírito o vaso físico, porém do mesmo estágio evolutivo em que se localiza, para um novo tirocínio ou para restituir o equilíbrio dissipado em etapas decorridas. Porém esta não é uma prática inaugurada ou exclusiva do espiritismo. Segundo Prandi:

[...] A crença na reencarnação parece ter se originado na índia e ter sido introduzida no hinduísmo por volta do século VI a.C. Segundo a doutrina, as almas de todos os seres vivos - plantas e animais, homens e até mesmo deuses - estão sujeitas a um ciclo perpétuo de renascimentos. [...](Prandi, 2012, p. 36) 
A primeira referência escrita no oriente à ideia de reencarnação tem no mínimo 2.600 anos. Aparece nas Upanixade, uma parte dos Vedas, as escrituras sagradas do hinduísmo. Porém a ideia de reencarnação é um sistema central, análogo à religiosidade e a filosofia desde eras ainda mais antigas, seus indícios remontam há 12 mil anos, onde existia o costume de se enterrar os mortos em posição fetal. Estudos arqueológicos apontam que esta referida prática tinha como intuito à preparação dos corpos para uma nova vida. Os antigos egípcios preparavam textos quais eram depositados dentro dos esquifes e destacavam as qualidades dos mortos, a fim de convencer Osíris a conceder o direito de o espírito reencarnar. Várias culturas em diferentes momentos históricos mencionam a ideia de reencarnação em seus costumes, mas foi apenas em 1857 na França, por meio de Hippolyte Léon Denizad Rivail (1804-1869), que adotou o nome de Allan Kardec, de quem se dizia reencarnação, que ideia da reencarnação recebeu seu maior impulso moderno. Com a publicação do primeiro de seus sete livros (O Livro dos Espíritos), em abril de 57, Kardec deu início a uma nova religião.

A comunicação com os espíritos desencarnados, segundo Allan Kardeck, tanto é possível como deve ser estimulada. A comunicação pode ser compreendida como a maneira de ser tornar conhecida uma gama de elementos ou dados entre os espíritos desencarnados e os seres encarnados. Esta comunicação pode se dar de varias formas, dependo do nível mediúnico que o interlocutor possui, tomemos como exemplos duas entre diversas formas de comunicação, a psicografia, uma manifestação mediúnica realizada através da escrita, podendo ocorrer através do ditado, onde o espirito narra o conteúdo ou a pela utilização da mão do médium pelo espírito desencarnado. A outra forma de comunicação é a psicofonia, onde o médium cede algumas de suas faculdades como à fala por exemplo. Conforme Prandi discorre em seu livro: Os mortos e os vivos: uma introdução ao espiritismo:

[...] A vida na terra nada mais é que um pequeno e transitório momento na trajetória do espírito, de modo que a compreensão do ser humano e de tudo que ele faz aqui só é possível se se levar em conta seu passado constituído de outras vidas e seu futuro muito além da morte. Todos que vivem na terra nada mais são que os espíritos reencarnados, que podem ter habitado e ainda irão habitar diferentes mundos em suas diferentes reencarnações.(Prandi, 2012, p. 39)

Outro ponto característico e que fundamenta a compreensão da doutrina e que se relaciona diretamente com a ideia da reencarnação, é a relação com a lei do karma. Muito embora essa fosse uma ideia não muito conhecida no ocidente até muito recentemente, este processo remete sua origem a milhares de anos, remete a antiga Índia, considerada por muitos como o berço da espiritualidade humana. Segundo o líder “carismático" (Weber, 1981) 
Prabhupada, fundador da Sociedade Internacional para Consciência de Krishna, a lei do karma é um processo que:

\footnotetext{
Ensina-nos a viver uma vida ideal, repleta de boas qualidades espirituais e complementadas por um enorme caudal de conhecimento filosófico acerca do Absoluto, da renuncia, da vida eterna, etc., o que proporciona uma vida feliz, iluminada por grande paz interior. (Prabhupada, 2010, p. 7)
}

Para os espíritas, cada ser humano é um espirito imortal, quando encarnado, este espirito herda as consequências boas ou más de suas vidas anteriores, o homem é a síntese de suas experiências. A vida do espírito são os acontecimentos de cada instante a se encadearem incessantemente, é o resultado de suas atividades anteriores. O Karma é lei que ajusta o efeito a sua causa, todo o bem ou mal que tenha sido feito trará consequências boas ou más, para esta vida ou próximas existências.

Esta breve análise de alguns fundamentos do espiritismo esclarece de certa forma algumas particularidades da doutrina, ademão auxilia a pensar as possibilidades de organização e conduta individual de seus adeptos, além de ajudar a justificar a hipótese de configuração social do grupo, conforme suas crenças se arranjam em seu comportamento singular e social.

Na definição do objetivo desta pesquisa - o estudo e levantamento das hipóteses sobre as configurações da sociedade, pela ótica dos atores sociais vinculados à doutrina espírita, fezse necessário configurar, perante a pesquisa, o Espiritismo como um sistema religioso a partir da seleção de um grupo específico, de forma que seja possível caracterizar a doutrina a partir de alguns de seus traços centrais e adentrar na complexidade do movimento espírita cujo grupo selecionado se situa.

Desta forma, ao longo do segundo semestre de 2018, acompanhamos atividades no centro Espirita Amor a Verdade no distrito barbacenense de Ponte do Cosme; realizamos entrevistas criteriosamente elaboradas com base no projeto; ampliamos os estudos sobre os temas abordados na pesquisa, de forma que possamos acessar assim a memória coletiva do grupo social abordado.

\section{O Centro Espírita Amor À Verdade}

A pesquisa revela que a história do centro espírita Amor a Verdade remete ao inicio do século XX, intimamente ligada à família de Salute Bertolla Pereira e seus filhos. Em meados 
da década de 20, os jovens Pati e Alexandrino, filhos de Salute, começam a apresentar "problemas", que posteriormente foram compreendidos como processo obsessivo, um fenômeno que segundo a doutrina é entendido como uma interferência que se dá por um processo parecido com o que acontece nas frequências de rádio, quando uma emissora clandestina passa utilizar determinada frequência operada por outra, prejudicando a transmissão original. Essa interferência estará tanto mais assegurada quanto mais forte e potente se apresentar, até abafar quase por completo os sons emitidos pela emissora burlada, encontrando em sua vítima os condicionamentos, a predisposição e as defesa desguarnecidas, disso tudo vale o obsessor para instalar sua onda mental na pessoa visada.

Este acontecimento levou esta família a buscar o que definem como "as luzes da doutrina espírita". A família começou então a frequentar o centro Coração de Jesus em Barbacena, buscando ajuda da comunidade espírita. Por volta de 1938, formaram um pequeno grupo no distrito e começaram a realizar reuniões espíritas na residência de Pati Pereira Mazzoni e Ângelo Mazzoni. Segundo conversas realizadas durante trabalho de campo, a residência do casal era humilde e pequena, e o fluxo de pessoas interessadas pela doutrina aumentavam então seus proprietários decidiram por construir uma grande sala exclusivamente para as realizações das reuniões. Neste período o grupo era constituído por moradores de Ponte do Cosme e de Dr. Sá Fortes, distrito também constituído por imigrantes italianos da cidade vizinha de Antônio Carlos, até que mais tarde fundaram seu próprio centro.

Até 1944 os trabalhos foram realizados na residência de Ângelo e Pati, quando devido à demanda, foi construída a sede antiga, uma pequena construção que resiste de pé ainda hoje. Segundo os relatos, em agosto do mesmo ano houve o $1^{\circ}$ Congresso Espírita Mineiro, contando com a representação do centro por parte de José Abrantes Júnior, onde foram criadas as Alianças Municipais Espiritas. Em setembro de 1944 o centro Amor a Verdade é registrado em cartório na cidade de Belo Horizonte, ainda no mesmo mês, integrantes do centro espírita redigiriam o termo de compromisso e filiação a Federação Espírita de Minas Gerais, fundando assim, para todos os fins, o Centro Espírita Amor a Verdade.

A sede foi erguida sobre o terreno doado por Joaquim Pereira, sendo inaugurada no dia 25 de dezembro de 1944 para a comemoração do natal de Jesus. As reuniões mediúnicas, no entanto, continuaram sendo realizadas na residência de Pati até 1963, quando foram transferidas para a sede. Após desencarnar, Pati Mazzoni, em reconhecimento a seu trabalho e dando continuidade ao mesmo, torna-se mentora espiritual da Escola de Evangelização, qual recebe seu nome. Hoje o centro é um grande edifício, com uma grande quantidade de salas capazes de comportar separadamente todas as atividades desenvolvidas (no entanto, nos foi 
dito que já existe a demanda de aumentar as instalações devido a grande procura) tais como a reunião pública que acontece nas sextas feiras. Esta é a reunião com maior fluxo de pessoas, contando com participantes até mesmo de fora da comunidade, neste encontro realizam o passe, um processo de troca ou doação de fluidos espirituais, qual serve para auxiliar no equilíbrio de quem o recebe. Nesta mesma reunião há também a distribuição da água fluidificada, onde certa quantidade de água é armazenada na sala onde ocorre o passe, absorvendo assim as energias das orações e logo depois é distribuída para todos os participantes.

Entrevistado: No domingo pela manhã tem a evangelização da criança e do jovem, segunda é o estudo e pratica da mediunidade, na terça é o estudo da juventude, a reunião da juventude, na quarta é a reunião mediúnica, reunião fechada. Na quinta é uma mescla, tem reunião de vibração a gente falda irradiação, ocorre de dois em dois meses na primeira quinta feria e nos meses pares a reunião da diretoria da casa a reunião administrativa. A quinta feira é mais aberta, a não ser quinze em quinze dias onde é realizada essa reunião de vibração, quando alguém precisa de alguma coisa realizamos outros eventos. Na sexta é o que chamamos de reunião publica, aberta ao público onde é feita as palestras, junto da evangelização também, tem a educação dos espíritos para as crianças. No sábado está sendo feito um estudo doutrinário onde estamos estudando as obras de André Luís.

Percebemos que as famílias pioneiras da introdução da doutrina e instalação do centro no município, ainda hoje, quase cem anos depois, detêm certo monopólio dos cargos de poder dentro do centro espírita, observações da pesquisa apontam que as pessoas que hoje ocupam os cargos centrais de comando e distribuições das funções do centro, assim como os que estão sendo formados para assumirem estes cargos futuramente, ou são descendentes diretos das famílias pioneiras, ou tem alguma ligação direta com estes, como o matrimônio por exemplo.

\section{Ponte Do Cosme E O Mundo Moderno}

Como nos demais campos da sociedade, existem também na religião uma constante disputa entre os agentes, pela imposição de seu domínio, de forma que mudanças decisivas podem ser operadas em diversos campos da vida coletiva, possibilitando o surgimento de uma série de valores dentro da prática religiosa, capazes de dirigir a racionalização da conduta dos fiéis. Existemaspectos consequentes das práticas da religiosidade que são capazes de intensificar e interferir de modo sistemático na postura, objetivação e socialização, em outras palavras, gerar uma ética religiosa. Segundo Weber, existe um processo de racionalização e emparelhamento, reflexos da concepção de mundo por parte da comunidade religiosa, capazes de, por exemplo, justificar aos fiéis por que alguns são mais afortunados que outros, capazes 
de fazer com que os crentes alterem seus modos de vida de maneira a alcançar um ideal sagrado, uma forma de negar os bens mundanos sistematizando, reorientando a vida comunitária e religiosa do grupo social, partindo de um forte movimento ético religioso. Entendemos então que a ética religiosa penetra profundamente na ordem social, por tanto, buscamos visualizar e analisar o papel da religião dentro da estrutura social de Ponte do Cosme, as estratégias da prática religiosa, e sua influência sobre a conduta do indivíduo e do grupo social local.

Para delimitarmos a realidade social do distrito, realizamos uma análise a partir dos estudos de Erik Wolf (2003) a cerca dos tipos de campesinato, a fim de obtermos uma visão teórica referente à comunidade do distrito. Wolf trabalha com as perspectivas dos tipos de comunidades: as corporadas, qual delimita uma identidade estrutural que estimula o equilíbrio tradicional, tendo o poder intimamente interligado a uma lógica religiosa e uma forte ética local, estando mais fechados às interferências de fora da comunidade. Já as comunidades abertas, ainda segundo Wolf, possuem um melhor trânsito com o mundo exterior, com as demandas de fora, capazes de absorver rapidamente mudanças em sua lógica de produção e de reformular seus laços sociais.

À medida que entendemos a estrutura organizacional do grupo social do distrito, começamos a ponderar sobre a abertura do grupo frente à lógica de modernidade ou se resistem a ela. Berman (2007) tece a modernidade como um paradoxo, uma unidade de desunidade, um tácito conjunto empírico de experiências individuais para consigo mesmo e para com os outros do grupo social. Neste desenho teórico de Berman, podemos encaixar a ilustração de modernidade feita por Bauman (1998), quando explica que a modernidade desencadeou fatores sociais e psicológicos capazes de suspender temporariamente o processo civilizatório que habitualmente regula o comportamento humano. Partindo da ideia de que todos os instintos morais da conduta humana são produzidos socialmente, o processo que regula a conduta humana se dissolve de imediato assim que os indivíduos encontram-se em uma condição de anomia social (Durkheim) ou, em outras palavras, quando a sociedade encontra-se em um estado de ausência ou desintegração das normas sociais, um dos objetivos na pesquisa é visualizar e analisar a profundidade em que a ética religiosa penetra na sociedade local, ajudando a afirmar a normas sociais do grupo e a preservar uma estrutura tradicional, transmitindo de geração a geração, as características culturais e principalmente religiosas, com seus ritos, costumes e crenças dentro do distrito, de modo que conseguem resistir, de certa forma, a toda volatilidade e curta validade das relações e organização do mundo moderno. 
Segundo Freud (2014), nestes grandes conjuntos socialmente organizados do mundo contemporâneo ocidental, o homem precisa se acomodar, porém se acomoda mal, pois é portador de uma vitalidade inerente, errante e multiforme, difratado por diferentes universos simbólicos. O que gera um enorme conflito ante o sistema de racionalidade instrumental e do convívio social da lógica do sistema moderno, onde o homem perde o domínio até mesmo de seus instintos em virtude do outro, passa a organizar toda sua vida, social ou singular, pautada no convívio com os outros, o que gera uma série de mal-estares a partir do convívio social, visto que para a uma convivência minimamente sustentável, os indivíduos devem controlar seus instintos e desejos. Entendemos que é justamente sobre esta esfera que a religião opera desempenhando papel fundamental, regulando o individuo a partir do campo do sagrado, pautando sua conduta através da promessa ou do castigo, é neste sentido que entendemos que a religião desempenha um papel fundamental dentro da sociedade.

As organizações fundamentadas nos princípios da religião são capazes de adentrar profundamente na vida de seus adeptos, tanto em nível individual quanto em nível coletivo. As crenças religiosas possuem competências de influenciar e mesmo de direcionar o comportamento humano em todas suas dimensões, ressignificando a compreensão de toda experiência religiosa, refletindo nos arranjos sociais. A prática religiosa ao mesmo tempo em que parte da unidade, do íntimo de cada indivíduo em sua forma mais singular, de fato só se projeta como um movimento unificado nos arranjos coletivos das celebrações e cultos, entre outras disposições ritualísticas. Partindo deste pressuposto, de que a religião, ou mais diretamente, a pratica religiosa só se dá em sua forma completa no meio social, dentro da interação programada de indivíduos em ato irrefutável de sociabilidade, visto que, segundo Simmel (2006: 64), “[...] a forma é a mútua determinação e interação dos elementos pelos quais se constrói uma unidade" é possível entender que antes de tudo, a religiosidade é um meio eficiente de aproximação ou segregação de pessoas.

Tomando a religiosidade como veículo de intercâmbio, como norteadora da problematização da interação ou movimento social entre os indivíduos do distrito de Ponte do Cosme, futuramente na pesquisa, será ressaltada com certa particularidade as hipóteses levantadas a partir do trânsito social entre espíritas e católicos na comunidade local, ademais, o foco é dado em primeiro momento nas nuanças da doutrina espírita, e da autoimagem que os indivíduos, os atores sociais deste grupo, fazem de si mesmos.

Para uma análise de comportamento individual e da "fachada" (Goffman, 2014) do grupo social, que se caracteriza pela aceitação e prática da doutrina espírita, é necessário mais a frente, uma breve contextualização daquilo que podemos denominar como ethos da referida 
doutrina. Goffman (2014: 34) define fachada como "[...] o equipamento expressivo de tipo padronizado intencional ou inconsciente empregado pelo indivíduo durante sua representação", este conjunto expressivo é adotado pelo grupo como um tipo de código de conduta em dados momentos, tornando-se desta forma uma reprodução coletiva e social, capaz de se adaptar conforme a abrangência da sociedade em que é ajustada.

Perceber os princípios que motivam as instruções da doutrina espírita, assim como a "fachada" (Goffman) adotada, pode proporcionar a compreensão de como seus atores sociais adequam seus valores, a forma como tendem a calhar sua conduta a partir da "fachada" social adotada e dos impulsos singulares buscando suas finalidades particulares. Segundo Simmel (2006: 60) "[...] essas interações que os portadores individuais daqueles impulsos e finalidades formam uma unidade -mais exatamente uma sociedade". Compreender como os costumes e códigos da doutrina influenciam individualmente e como isso se reflete na formação das instruções e postura do grupo social, visto que a pesquisa aponta que os espíritas detêm maior poder simbólico dentro do distrito, aparenta ser um dos fatores que adequa a conduta e todo "conteúdo e matéria" (Simmel) na vida dos adeptos da doutrina espírita e influenciando até mesmo no comportamento social dos católicos. Simmel define conteúdo e matéria como:

[...] tudo que existe nos indivíduos e nos lugares concretos de toda realidade histórica como impulso, interesse, finalidade, tendência, condicionamento psíquico e movimento nos indivíduos - tudo o que está presente nele de modo a engendrar ou mediatizar os efeitos sobre os outros, ou a receber esses efeitos dos outros. (Simmel, 2006. p. 60).

A pesquisa aponta que a maneira como os espíritas se organizam em suas estruturas, a partir de certa "ética espírita", um código consciente ou inconsciente presente nos pilares que fundamentam sua conduta individual, reflete em todo grupo social local. O que nos ajuda a visualizaro lugar da religião como um elemento fundamental para organização do grupo social do distrito,tendo a religião como delimitador de posições sociais e de identidade, de forma que pautam suas condutas por uma forte ética religiosa:

Entrevistado:Eu não diria do centro, mas do comportamento do frequentador né, daquele que busca na doutrina espirita o esclarecimento, então se nós somos verdadeiros espíritas né, nos tornamos verdadeiros cristãos, e o verdadeiro cristão muda seu comportamento, isso ai que vai fazer toda diferença, é o reflexo da pessoa na sociedade e hoje a gente obtém isso, e muito, é comum às pessoas chegarem e falar assim: - Eu não entendo nada disso, mas eu gosto de ver o comportamento do fulano ou do cicrano com base no conhecimento que ele tem da vida espiritual. Então isso ai que influência, por que a casa em si não, é a construção física, mas o comportamento que vai fazer toda diferença. 
Entrevistador: Vocês percebem então que existe uma diferença no comportamento da comunidade aqui do distrito, influenciada pela doutrina espirita?

Entrevistado:Tem sim, é muito mais fraterno, a gente passa a ver o problema do outro como sendo um problema nosso, todo mundo procura se ajudar dentro do possível, dentro das necessidades e das condições, a convivência passa a ser muito mais fraterna.

E essa compreensão que a gente vê da doutrina ... você começa a ter uma modificação nas suas atitudes e as pessoas começam a notar isso. Às vezes a gente conversa com uma pessoa e ela diz:- Você é espirita "né".

Por causa desse comportamento, não somos melhores que ninguém não, todos nós estamos no mesmo patamar, independente de religião... e quando a gente começa a modificar as nossas atitudes, as pessoas que estão ao lado começam a nos ver e muitas vezes também se modificam. Então acaba que é uma... aquela coisa, a palavra convence, mas o exemplo é que arrasta.

É curioso como mesmo dentro de uma comunidade que se organiza de maneira tão tradicional, pode frutificar uma religião moderna e dinâmica como o espiritismo,colocando a ideia do indivíduo e da razão em posição central na discussão: "você começa a ver nesse crivo da razão, na compreensão do antes, do hoje e do por vir" (fala de um entrevistado), como na sua pedagogia, por exemplo, como explica outro entrevistado:

... a doutrina é uma coisa dinâmica. Se olharmos em termos, mesmo da casa aqui, como nós fazíamos os trabalhos há vinte anos atrás, há 10 anos atrás, hoje temos um processo diferente, o que chamamos dentro da doutrina de evolução. Buscamos sempre essa evolução, do ser, e com a evolução do ser você evolui todas as atividades que você tem.

Ao mesmo tempo em que apresentam esta dinâmica, esta constante transformação no elemento da religião, preservam costumes como a prática das famílias se visitarem, um indício do conservadorismo local, do coletivismo, mantendo também o predomínio do sagrado, da sacralização tanto na esfera política e social. Apesar de estarem em trânsito constante com a lógica moderna da organização urbana, quando se deslocam todos os dias para trabalharem na cidade, dispõem de mecanismos para que os elementos fugazes do mundo moderno não adentre a organização do grupo local, preservando tradições, sobre tudo no que diz respeito à estrutura familiar, mantendo os casamentos formais, geralmente ainda jovens e com os filhos construindo suas casas ao redor da casa dos pais.

\section{Considerações Finais}

A princípio, pensávamos que o fato do distrito ter se formado a partir de uma colônia de imigrantes italianos exerceria uma forte influencia sobre a cultura e organização do distrito, porém a pesquisa revelou que os moradores não destacam o fato de serem 
majoritariamente descendentes destes imigrantes como um fator de relevância para seus costumes e organização, não existem festas temáticas ou alguma outra forma de preservação e resgate dos costumes italianos. Por outro lado, o estudo aponta que o distrito se enquadra em um modelo de comunidade parcialmente corporada, com forte resistência a aceitar novos moradores e de introduzirem as formas de vida do mundo moderno no convívio cotidiano local, dispondo de mecanismos para se "protegerem" da introdução desta lógica de organização, como por exemplo, a resistência em venderem lotes a forasteiros. Alguns moradores tecem críticas à modernidade, mesmo que implicitamente, algo que era de se esperar tendo em vistas que é uma comunidade formada por famílias tradicionais e politicamente conservadoras, como revela a pesquisa, mas que apresenta, de certa forma, um caráter dicotômico por ser uma comunidade fincada em valores tradicionais, mas abraçarem uma religião moderna como o espiritismo que toma como central a ideia de indivíduo, porém alicerçada em preceitos tradicionais. A pesquisa aponta a introdução de elementos da modernidade, não implica de forma alguma em negar os traços tradicionais do município, que as possibilidades de interseção entre o tradicional e o moderno, passa sobre tudo por um processo de reconfiguração, ou seja, ao mesmo tempo em que um elemento influencia o outro também se adapta e se modifica a partir dele, resultante de interaçõesadaptativas.

O fato de Ponte de Cosme compor uma comunidade assentada há mais de um século, formada por famílias que perpetuam, de certa forma, suas tradições, e que mesmo assim, houve a inserção do espiritismo, uma religião moderna, desde muito cedo no cenário religioso local é um dos principais problemas que iremos abordar futuramente na continuidade da pesquisa. Esta é uma das configurações distintas que o estudo revela, mostrando que Ponte do Cosme é um local impar, que guarda características únicas como não possuir nenhuma outra manifestação religiosa institucionalizada em seus territórios, apenas o catolicismo e o espiritismo, quebrando com a hegemonia dos números de católicos do município a qual pertence, além de guardar peculiaridades, como o fato da doutrina espírita se situar em posição de superioridade nas disputas pelos bens simbólicos da religiosidade do distrito, conforme a pesquisa revela, atraindo pessoas até mesmo de outros municípios para participar das atividades do centro, como podemos ver em um trecho de uma das entrevistas:

\footnotetext{
...no domingo principalmente, percebemos que cada vez mais, pessoas procurando a educação da alma, trazendo crianças e jovens. Ah alguns anos atrás era mais restrito às crianças dos filhos dos espiritas aqui de Ponte do Cosme. Hoje está aberto e estamos sempre recebendo pessoas de Barbacena, Vasconcelos, Sá Fortes, que vem pra cá.
} 
Ainda referente ao centro espírita de Ponte do Cosme, a pesquisa revela que existe um monopólio hereditário em relação aos cargos de poder dentro do centro espírita, ainda hoje quase um século depois, aqueles que ocupam os cargos mais relevantes dentro do centro, ou são descendentes da família pioneira da doutrina, ou possuem algum laço estreito de parentesco como o matrimônio por exemplo.

Outro dado que percebemos é que existe um conflito velado, mesmo que alimentado muito mais pelos católicos, existe uma disputa pela fé que aparece nas narrativas dos moradores quando dizem das dificuldades que algumas pessoas enfrentaram quando se converteram ou se convertem à doutrina, a pesquisa também revela que há uma separação territorial das residências dos espiritas e dos católicos. As famílias, salvo algumas exceções, construíram suas casas perto do centro espírita ou da igreja, de acordo com suas preferências religiosas.

Ponte do Cosme mantem um campo religioso peculiar, onde outras organizações religiosas como os neopentescostais, por exemplo, não conseguiram adentrar, e que possibilita que o espiritismo, através do centro Amor á Verdade, exerça um papel protagonista na conjuntura local, frente ao tradicionalismo católico do município, tornando-se um local de referência na rede espírita da cidade e região. Em virtude destas constatações, estamos realizando uma análise cuidadosa acerca das particularidades do microcosmo local, no intuito de compreender os sentidos, as condições e as estratégias de preservação dos costumes da sociedade local, que ao mesmo tempo em que conserva uma lógica social de organização tradicional, abriga em posição de destaque, uma religião fruto do mundo moderno, que trás o indivíduo para o centro da reflexão, e ainda sim se alicerça nestes valores tradicionais, como a ideia de coletivismo e fraternidade.

Tendo em vista que estamos inseridos em um país que possui uma forte influência religiosa, uma análise sociológica aprofundada sobre o elemento religioso da sociedade de Ponte do Cosme se faz fundamental para que possamos compreender suas estruturas sociais e assim ampliar e abarcar o estudo para o campo social e religioso de Barbacena, a fim de realizarmos uma leitura mais aprofundada acerca das distintas formas e evolução do grupo social do distrito em relação ao município e assim tecer uma análise histórica, cultural e social a partir das características de seu campo religioso. 


\section{Referências Bibliográficas}

BAUMAN, Zygmunt. Introdução a Sociologia depois do Holocausto - In: Modernidade e Holocausto. Rio de Janeiro: Zahar, 1998.

BERMAN, Marshall. Tudo que é Sólido Desmancha no Ar: A aventura da Modernidade. São Paulo: Cia das Letras, 2007.

BOURDIEU, Pierre. Sociólogos da crença e crença dos sociólogos. In: Coisas Ditas. São Paulo: Brasiliense, 1990.

.A Economia das Trocas Simbólicas. Organização de Sérgio Miceli. 6 ed. São Paulo: Perspectiva, 2005.

CASTRO, M. Laura V. O que é o Espiritismo. Segunda Visão. Antropológica, São Paulo: Editora Brasiliense, 1985.

DUBY, Georges. As três ordens ou o Imaginário do Feudalismo. 2 ed. Lisboa: Estampa, 1994.

FREUD, S. Obras Completas, volume 18. Companhia das Letras, São Paulo, 2014

GEERTZ, Clifford. A Interpretação das Culturas. Rio de Janeiro: LTC, 2008.

GOFFMAN, Erving. A representação do eu na vida cotidiana, Petrópolis: Vozes, 2014.

HALBWACHS, Maurice. A memória coletiva. São Paulo: Vértice, 1990.

MANNHEIM, Karl. O problema sociológico das gerações. Tradução: Cláudio Marcondes. In.:Marialice M. Foracchi (org), Karl Mannheim: Sociologia. São Paulo: Ática, 1982.

PRANDI, REGINALDO. Os mortos e os vivos: uma introdução ao espiritismo. São Paulo: Três Estrelas, 2012.

PRABHUPADA ,Abhay. Karma a Justiça Infalível, São Paulo; Sankirtana, 2010.

ROUSSO, H. A memória não é mais o que era. In.: FERREIRA, Marieta de Moraes \& AMADO, Janaína (orgs). Usos e Abusos da História Oral. $5^{\text {a }}$ edição. Rio de Janeiro: Fundação Getúlio Vargas, 2002.

SIMMEL. Georg.Questões Fundamentais da Sociologia. Rio de Janeiro: Zahar, 2006.

WEBER, M. A Etica Protestante e o Espírito do Capitalismo. Companhia das letras, São Paulo, 2007.

WEBER, Max. Ensaios de Sociologia. Ed. Guanabara: Rio de Janeiro, 1981.

WOLF, Eric W. Tipos de Campesinato Latino-Americano: Uma discussão Disciplinar. In: Antropologia e Poder. Brasilia/Campinas: EdUnB/Editora Unicamp, 2003. 


\title{
Renovação Carismática Católica e política em Barbacena - MG
}

\author{
Catholic Charismatic Renewal and Politics in Barbacena - MG
}

Luiz Ernesto Guimarães ${ }^{4}$
pr.ernesto@gmail.com

Marcela Gongora Lemuchi ${ }^{5}$

marcelaglemuchi@gmail.com

\begin{abstract}
Resumo: Este artigo busca compreender a relação entre Renovação Carismática Católica (RCC) e política em Barbacena-MG. Atualmente, diversas pesquisas têm estudado o avanço do movimento carismático no campo político, ao contrário do que se pensava no final do século XX. Essa aproximação tem resultado em uma agenda moral, defendendo interesses de setores conservadores do catolicismo. A presença de um vereador carismático na Câmara Municipal de Barbacena exemplifica isso. No entanto, além das pautas elaboradas a partir de um ideal religioso, há também outros temas que são defendidos, ampliando assim sua atuação politica para outros grupos sociais não necessariamente ligados à religião.
\end{abstract}

Palavras-chave: Antropologia da política; Catolicismos; RCC; Religião e política;

Barbacena-MG.

Abstract: This article seeks to understand the relationship between Catholic Charismatic Renewal (RCC) and politics in Barbacena-MG. At present, several studies have studied the advance of the charismatic movement in the political field, contrary to what was thought at the end of the 20th century. This approach has resulted in a moral agenda, defending interests of conservative sectors of Catholicism. The presence of a charismatic councilor in the Barbacena City Hall exemplifies this. However, in addition to the guidelines elaborated from a religious ideal, there are also other themes that are defended, thus extending its political activity to other social groups not necessarily related to religion.

Key-words: Anthropology of politics; Catholicisms; RCC; Religion and politics; BarbacenaMG.

\section{Introdução}

Religião e política tem protagonizado uma série de fatos ao longo da história humana que torna impossível dissociar uma da outra. Se isso ocorrer, reduzimos as possibilidades de compreensão da vida social. Na atualidade brasileira, por exemplo, seria quase impossível a compreensão do atual estado das coisas se afastássemos a religião do campo político. A intensificação da crise econômico-político-social, após o golpe de 2016, aprofundada com a eleição do candidato à presidência Jair Bolsonaro (PSL), de extrema direita, não pode ser explicado sem levar em conta o papel da religião nesse processo.

4 Doutor em Ciências Sociais (Unesp - Marília). Professor junto ao departamento de Ciências Humanas da UEMG - Barbacena.

5 Graduanda do curso de Ciências Sociais (UEMG - Barbacena). Bolsista PAPq-UEMG. 
Neste artigo especificamente, busca refletir sobre a relação religião e política em uma cidade do interior mineiro: Barbacena. Com aproximadamente 140 mil habitantes, ela fica situada na região da zona da mata, entre Belo Horizonte e Rio de Janeiro. É uma cidade histórica, com 227 anos. Fica próxima a outras cidades também históricas, como Tiradentes e São João del Rey.

A Renovação Carismática Católica (RCC) foi escolhida por ser um dos movimentos que mais estão em evidência no catolicismo nas últimas décadas. Tem atraído pessoas de todas as idades, especialmente as mais jovens, muitas inclusive que já não eram mais frequentes às missas semanais. Com uma linguagem mais próxima do cotidiano das pessoas, num tom de informalidade, sem toda a seriedade e ordem que há nas missas tradicionais, a RCC tem tido um papel importante para o catolicismo, que vem declinando nas últimas décadas segundo dados do IBGE, ao contrário das igrejas evangélicas que têm experimentado o aumento no número de fieis..

O estudo da política pela antropologia permite "explicar como os atores sociais compreendem e experimentam a política, isto é, somo significam os objetos e as práticas relacionadas ao mundo da política (Kuschnir, 2007, p. 163). Assim, foi realizado pesquisa de campo em alguns grupos de oração e na Câmara Municipal de Barbacena. Foram realizadas entrevistas semi estruturadas, além de pesquisa nas redes sociais de alguns fieis carismáticos.

\section{A Renovação Carismática Católica e a política}

Uma das primeiras pesquisas sociológicas sobre a Renovação Carismática no Brasil, realizada no final da década de 1970, por Pedro Ribeiro de Oliveira (1978), traz algumas contribuições importantes sobre a RCC e sua relação com a participação social e/ou política. Por meio de pesquisa quantitativa, aplicada a diversos grupos na época, constata o sociólogo que $47,3 \%$ daqueles que responderam o questionário afirmaram não possuir engajamento social, enquanto $17,8 \%$ declaram possuir engajamento social, especificando tal comportamento, geralmente de maneira assistencialista, como o trabalho com dependentes químicos.

Sobre isso, Reginaldo Prandi considera que "o primeiro objetivo da vida carismática é a renovação interior, e qualquer atuação no campo social deve ser resultado do amadurecimento interior e individual" (Prandi, 1998, p. 171).

Em outro texto, o cientista social discute como segmentos religiosos percebem o mundo e as possíveis rejeições ao mesmo. Observando as CEBs, por exemplo, há a negação 
do mundo na maneira como é apresentado, propondo-se a transforma-lo. No caso da Renovação Carismática, semelhante ao pentecostalismo, "é uma religião que rejeita o mundo, mas não pretende transforma-lo. Ao contrário, ele prega a retirada do fiel para o interior da comunidade de culto, identificando o resto como território do demônio" (Prandi, 1992, p. 86).

Ainda, de acordo com Prandi, na analogia feita com o pentecostalismo, compreende a proposta de construção de um novo mundo sob o paradigma religioso, cristão, “onde não há lugar para o outro, o diferente, o plural" (Prandi, 1992, p. 86). O processo de mudança social, nessa perspectiva, deve acontecer "a partir de transformação na espiritualidade de cada um. Tais transformações devem resultar em mudanças na vida família e depois, lentamente, em mudanças no interior de toda a sociedade. Esta é a fórmula tradicional: primeiro mudar o indivíduo, e então a sociedade por força mudará” (Prandi, 1998, p. 171).

Nessa mesma direção, Pedro Ribeiro de Oliveira observa nos textos da RCC que "a atuação no campo social e político deve ser uma decorrência da renovação interior, que é a primeira não só cronologicamente como também a primeira em ordem de importância" (Oliveira, 1978, p. 37).

O sentido contido na mensagem da Renovação Carismática demonstra a preocupação "com a preservação da família e seu desinteresse pelo que se passa na sociedade. Qualquer mudança social é sempre concebida como projeto de moralização, de uma moral do indivíduo, do sexo e das relações mais internas da vida familiar" (Prandi, 1998, p. 171).

Para Oliveira, a partir de textos oficiais da RCC, a "ênfase na interioridade do reavivamento religioso não exclui, teoricamente, um impulso no sentido da ação social" (Oliveira, 1978, p. 36). Constata este autor, na perspectiva das lideranças desse movimento, um profundo vínculo entre a vida espiritual e o engajamento social.

Nas palavras de dom Cipriano Chagas, um dos primeiros organizadores da RCC no Brasil e fundador da Comunidade de Aliança Emanuel, no Rio de Janeiro, Oliveira destaca que "seria pois um engano caracterizar a Renovação Carismática meramente como uma renovação de um relacionamento pessoal individual com Deus. É isto primeiramente, sem dúvida, mas ao mesmo tempo é uma renovação da comunidade cristã, uma edificação do corpo de Cristo" (Oliveira, 1978, p. 36).

Ainda de acordo com Pedro Ribeiro de Oliveira (1978), na concepção do monge beneditino Cipriano Chagas, os grupos de oração são casos particulares que, após um processo de amadurecimento, tornam-se importantes instrumentos de transformação social. Oliveira, no entanto, contesta tais prerrogativas, afirmando, por meio dos dados levantados 
em sua pesquisa, que o engajamento social na Renovação é bem restrito, principalmente no âmbito dos membros; entre os dirigentes a proporção é um pouco maior (Oliveira, 1978).

Júlia Miranda em sua pesquisa sobre a Renovação Carismática, segue o mesmo viés de Pedro Ribeiro de Oliveira:

\begin{abstract}
A inserção social dos grupos carismáticos é, na esmagadora maioria dos casos, de natureza assistencialista, embora haja experiências de organização popular para atuação de populações carentes em mutirões e manifestações reivindicativas, criação de cooperativas e projetos de formação pedagógica e profissional. Mas esses são ainda casos isolados (Miranda, 1999, p. 52).
\end{abstract}

Sobre o envolvimento da Renovação Carismática na participação política, Emerson Sena da Silveira (2008) observa dois momentos distintos que explicam esses números da pesquisa de Pedro Ribeiro de Oliveira (1978), cuja demonstração de retirada da vida política é nítida. O primeiro momento, entre as décadas de 1970 - época da implantação da Renovação no Brasil - e 1990, “a RCC permaneceu alheia aos movimentos políticos, dizendo-se espiritual, com uma finalidade principal, que seria renovar o homem e a igreja, trazendo uma 'experiência pessoal' do amor de Deus por meio do exercício dos chamados 'dons carismáticos"” (Silveira, 2008, p. 56). Nesse período, diversas pesquisas foram desenvolvidas, constatando o afastamento do religioso da esfera política, conforme demonstra Oliveira (1978).

O segundo período da RCC no Brasil abordado por Emerson Silveira (2008) se desenvolve a partir da transição do século XX para o XXI, a partir da reorganização da Renovação Carismática, bem como sua centralização e acentuado grau de burocratização. Assim, tal movimento "passou a engajar-se na arena política formal, num movimento similar ao que lançava os evangélicos em candidaturas vitoriosas no Legislativo, cuja estrutura era lastreada em uma rede de vínculos com os meios de comunicação (redes de TV e rádio), estratégias de marketing e negócios empresariais" (Silveira, 2008, p. 57).

Ainda, segundo o antropólogo, a atuação social e política da RCC, a partir desse momento de sua reestruturação no final do século XX, vincula-se a uma interpretação fundamentada em textos bíblicos e nas visualizações. Assim, Emerson Silveira questiona se a partir desse momento de mudanças na RCC haveria a formulação de um projeto político nesse segmento do catolicismo. O mesmo autor afirma que, na verdade, "a atuação política dos carismáticos não teria como objetivo formar um partido próprio, mas inserir os leigos no mundo da política, construindo o mito e a utopia da 'civilização do amor', expressão usada 
por sacerdotes e leigos ligados ao movimento ao se referirem a um projeto de 'reforma moral' da sociedade" (Silveira, 2008, p. 57).

A inserção no mundo da política, seja partidária ou não, está mediada pela ação do Espírito Santo, e, portanto, da própria Igreja e sua visão de mundo. Em entrevista, o padre Eduardo Dougherty, um dos precursores do movimento no Brasil, demonstra essa questão: "Deus realmente está derramando o Espírito Santo sobre o seu povo. E há uma carência de Deus. E nós temos que lutar pelos pobres, temos que ter ação social, mas todos movidos pelo Espírito Santo, não é?" (Carranza, 1998, p. 31).

Diante desse processo recente que a RCC vem trilhando em relação à política, Silveira chama a atenção para não cair no erro do desenvolvimento de pesquisas cuja interpretação da Renovação esteja posta em um único sentido, afirmando a existência de um caráter conservador e proselitista, abandonando, assim, uma abordagem mais ampla que contemple outras dimensões da relação desse movimento com a política. Para o autor, essa análise sumária "amputa diversas outras formas de compreender o fenômeno" (Silveira, 2008, p. 57).

Dessa forma, percebe-se que na Renovação teve em seu início uma postura de afastamento das questões políticas, especialmente partidárias, mudando seu posicionamento na virada do último século XX para o XXI, ocupando hoje diversas cadeiras no quadro do legislativo no Brasil. Sua atenção se voltou a tal ponto às questões políticas, sejam partidárias ou não, que foi formulado o Ministério de fé e política ${ }^{6}$.

\section{A RCC em Barbacena-MG}

Os movimentos dos grupos de oração da Renovação Carismática, não levaram muito tempo para que se difundissem na América Latina e por consequência chegassem ao Brasil. Com o desejo de, segundo Prandi, vivenciar algo além da hierarquia eclesiástica, e fazendo como instrumento disso, o Espírito Santo,

experimentar a transformação que o Espírito Santo podia operar nas pessoas. Sentiam que o aprofundamento na vida espiritual não podia resultar simplesmente da ação humana, o que sempre deixaria cada um sentir-se como órfão invadido pelo vazio e pelo desânimo (Prandi, 1997, p. 33).

6 O termo ministério é utilizado para delimitar áreas específicas de serviço. Assim, a RCC se divide em diversos ministérios, como: pregação, cura e libertação, formação, fé e política etc. Este último é responsável pelo trabalho de conscientização dos fieis. Apoia também aqueles que se sentem interessados em participar da política. Após eleitos, são acompanhados por esse ministério. 
Para os carismáticos seria uma forma de se aproximar de Deus usando uma abordagem diferente da tradicional, que vemos na Igreja Católica. Com isso, cativaram diversos fieis pelo país, os quais buscavam na fé a renovação do espírito. Com viés de cura e libertação, os grupos de oração agregam jovens e adultos dos mais variados contextos sociais.

Na região de Barbacena, estado de Minas Gerais, no ano de 1990 se dá início aos grupos de RCC. A renovação carismática católica apresenta um engajamento relativamente antigo, visto que, as RCCs começaram sua atuação dentro da igreja em 1970 no Brasil. O que consta como dados disponíveis nas pesquisas do IBGE, é que numa população estimada em 136.392 habitantes no último censo de 2018, 109.807 pessoas são católicos, 9.396 de evangélicos e 2.308 de pessoas seguindo o espiritismo, o que nos sugere que a predominância do catolicismo na cidade faz com que as RCC cresçam cada vez mais.

Entretanto, o que se foi apurado é que os grupos de renovação carismática estão com dificuldades em agregar fiéis, o número de praticantes nos grupos estão cada vez menor. Segundo um fiel carismático entrevistado,

\begin{abstract}
hoje o movimento diminuiu um pouco de uns anos pra cá. Isso a gente percebe em todo o país. O movimento chegou num ponto que inflou com muita gente no movimento e a gente tem uma proposta de vida, claro que à luz da Igreja, não uma igreja paralela dentro da Igreja Católica ${ }^{7}$.
\end{abstract}

Durante uma etnografia feita com o grupo Conversando com o Céu, que existe há seis anos aproximadamente, com o seu criador João que também apresenta engajamento político na região, observamos que o grupo é formado em sua maioria por adolescentes e jovens, um número de aproximadamente trinta pessoas. Durante a reunião, a forte presença da renovação carismática é notória, com cantigas, orações em línguas - glossolalia - e a participação coletiva, com danças e muita animação. Em um dos rituais, duas ou três pessoas dormiram no espírito santo (termo utilizado por eles quando uma pessoa se deita ao chão sob oração) que como explicação seria a forma de, segundo eles, experimentar a Deus. Hoje em dia a Renovação Carismática em Barbacena conta com o total de 35 grupos de oração, reunindo de segunda a domingo em diversas paróquias.

\title{
Os grupos de oração e a RCC
}

Os grupos de oração possuem um papel central na prática religiosa da Renovação Carismática Católica. Ou seja, participar da RCC é estar engajado em algum grupo de oração. 
É nesse ambiente que o fiel usufrui dos dons do Espírito Santo ou desenvolve tais dons; no caso dos servos, ocupando posições de liderança em relação aos demais. A glossolalia, os dons de cura, as profecias, o discernimento, o renovo espiritual, enfim, todos os elementos que caracterizam a religiosidade carismática são vividos essencialmente no contexto dos grupos de oração. Dificilmente será encontrado um fiel católico que se diz pertencente à RCC sem participar de algum grupo de oração, ainda que este não seja assíduo.

Para Flávio Sofiati, "os grupos de oração são o campo próprio do movimento carismático" (Sofiati, 2011, p. 220). Nesse mesmo sentido, Cecília Mariz afirma que "na base do movimento encontra-se a sua estrutura mais simples e básica formada pela rede de grupos de oração. Esses grupos constituem as células do movimento e a sua estrutura mais flexível. Todo participante da RCC está envolvido em um grupo de oração" (Mariz, 2003, p. 179).

Porém, para Reginaldo Prandi (1998), além disso, os grupos de oração possibilitam a complementação dos sacramentos normalmente encontrados na missa. Nesse caso, existe a possiblidade de se abrir certa concorrência entre a missa e os grupos de oração, embora o discurso de lideranças da RCC seja de conciliação, valorizando e incentivando a participação na missa semanal. Na prática, no entanto, percebe-se em alguns fieis a existência de uma escolha, muitas vezes pendendo para os grupos de oração em detrimento da missa.

Prandi destaca outro elemento que difere da missa: o caráter emocional presente nos grupos de oração. Sobre esses últimos, declara o cientista social: são "verdadeiras cerimônias da euforia, semanais, com duração de duas a três horas, são marcados por uma intensa carga emocional, que se torna cada vez mais forte no encaminhamento da reunião" (Prandi, 1998, p. 61). Se o tempo da missa é em média uma hora, com pouco espaço para a manifestação das emoções por parte dos fieis, nos grupos de oração esse fato se inverte, o que ajuda a explicar a permanência de um número significativo de fieis, ainda que o tempo de duração seja maior que nas missas.

Os grupos de oração são compreendidos por Flávio Sofiati (2011) como "anzol” que atrai os novos adeptos. Junto a eles, há também a influência das comunidades de vida, especialmente a Canção Nova, através dos meios de comunicação, que também têm contribuído significativamente nesse sentido. A música e as orações, bem como os testemunhos que são compartilhados resultantes das intensas orações, é outra dimensão desse atrativo. No caso da música, ou louvor, normalmente se utiliza diversos instrumentos como guitarra, bateria, teclado e contrabaixo, produzindo certa empolgação ao público presente. 


\section{Um vereador carismático na Câmara Municipal de Barbacena}

A Câmara Municipal de Barbacena possui 15 vereadores. Na atual legislatura há um jovem vereador, com 26 anos de idade, ligado à Renovação Carismática, filiado ao MDB. No sítio da Câmara há uma breve descrição em que demostra sua relação com o catolicismo: "Funcionário público estadual vem se destacando nos trabalhos sociais e na liderança de movimentos jovens da Igreja Católica. Está em seu primeiro mandato. Disputou uma cadeira na Câmara pelo PMDB, obteve 1.019 votos. Jovem e cursando gestão de Segurança Pública pretende fazer da participação popular e a transparência seus pilares na presente legislatura"8.

Desde adolescente tem participado do movimento carismático, o que determinou seu vínculo com o catolicismo. Embora de família católica, passou parte da adolescência alheio à religião. Foi por meio do contato com a RCC e a experiência da cura divina em um membro da família que o fez assumir a religião de forma definitiva.

Seu engajamento foi tão significativo que veio a se tornar importante liderança da RCC na cidade, atuando em diversos grupos de oração atualmente. É também músico e toca violão nas missas. O seu envolvimento com a política é recente, cerca de quatro anos atrás, resultado de sua participação na RCC:

\footnotetext{
Aqui em Barbacena a gente tem um sítio de dependente químico, fica lá na colônia Rodrigo Silva, tem quase 37 acolhidos no sítio, ai o padre João Henrique chamou as lideranças dos movimentos da Igreja e a gente achou que ia conversar sobre evangelização, estrutura do sítio. Daí no meio do almoço peguntou como está a política em Barbacena. Daí falei: "bom, do mesmo jeito, padre". Ele disse: "do mesmo jeito eu sei, mas o que vocês estão fazendo pela política em Barbacena? Ou vocês vão esperar que eu, padre italiano, já velho, que já dei minha contribuição para Barbacena e para o Brasil venha e faça alguma coisa?". Foi um tapa na cara da gente. Nunca tinha pensado em política partidária. Era ativista de rede social. Brigar na rede social era comigo mesmo, sabe? Dai aquilo foi um despertar pra gente?
}

Após esse encontro, começou a pensar sobre a possibilidade de se candidatar ao cargo de vereador. Após decidir-se, foi necessário fazer a escolha pelo partido político: "Não tinha filiação a nenhum partido. Daí a grande questão. (...) Alguns partidos na época a gente não comungava, com ideologia diferente do que a gente pensava, e o PMDB como a gente entendeu ser mais neutro, e em Barbacena ele é bem de centro mesmo, aí a gente acabou optando por ele" $" 10$.

$8 \quad$ www.camarabarbacena.mg.gov.br. Acesso em: 24 out. 2018.

9 Entrevista, 03102018. Vereador carismático de Barbacena.

$10 \quad$ Entrevista, 03102018. 
A adesão partidária se demonstra, dessa forma, pelo objetivo de disputar a eleição para o legislativo municipal. Semelhante, portanto, ao vereador londrinense do PTB, que também se viu na obrigação de filiar-se próximo ao período eleitoral (Guimarães, 2017). Não há assim, um partido específico que abriga as candidaturas na RCC. O partido político é o meio pelo qual se alcança seu maior objetivo: a participação política.

Isso também pode ser percebido pelo fato de não haver histórico de participação na trajetória partidária. No caso de uma vereadora petista na cidade de Londrina, entre a filiação e sua candidatura à uma vaga na Câmara Municipal levaram oito anos (Guimarães, 2017). Sua candidatura foi, portanto, consequência da vivência no cotidiano do partido.

Sua atuação política demonstra sua relação com a Igreja Católica: “O foco do nosso trabalho hoje é a vida, isso é fato, tanto que a gente tem esforçado para ajudar os hospitais aqui em Barbacena" (Entrevista, 03102018). Embora apresente a preocupação com as condições de alguns hospitais da cidade, "trabalhar pela vida" representa, sobretudo, a continuidade da criminalização do aborto no país. Em uma rede social, o vereador utilizou junto à sua foto principal a mensagem "\#juntospelavida", ao lado de uma imagem de um feto humano.

Nessa mesma rede social, postou um pequeno texto também de condenação à prática do aborto: “É um absurdo, inacreditável, ver alguns 'doutores' da lei pedindo que o assassinato de crianças, ainda no ventre da mãe, não seja considerado crime. Causa espanto ver que esses mesmos 'doutores' se dizem defensores de causas animais, direitos humanos e pelas minorias".

Já na Câmara Municipal, o vereador discursou em julho de 2018 sobre a moção de repúdio enviada ao STF e ao Congresso Nacional, em relação a $\mathrm{ADPF}^{11} 442$, ajuizada no STF pelo PSOL:

\footnotetext{
Requerimento 097/2018 de minha autoria e do vereador pastor Weverton, repúdio ao Supremo Tribunal Federal e Congresso Nacional, contra as razões da ADPF442, que é a ADPF que vem falar sobre o aborto, sobre matar uma criança no ventre da mãe, até as doze semanas. Eu queria agradecer a todos os nobres colegas que vieram assinar essa moção de repúdio, nós conseguimos 14 assinaturas dos nobres colegas dessa moção de repúdio ao Supremo, que primeiro, está tentando legislar, porque essa matéria não foi aprovada, os representantes legítimos da população disseram não ao aborto no país e agora estão tentando, o PSOL, partido PSOL, está tentando através da justiça legalizar o aborto no país até 12 semanas, três meses. Eu falei aqui na última sessão e eu volto a falar nisso, porque eu tenho um amigo que a esposa está grávida também e está com 12 semanas. Eu estive acompanhando minha esposa no processo da gravidez toda, da gestação, e eu vi na ultrassom com 12 semanas e a criança que eu vi ali é a mesma que hoje eu carrego nos braços. Então é um absurdo
}

11 Arguição de Descumprimento de Preceito Fundamental. 
falar que com 12 semanas não é uma criança, é um amontoado de células que está ali. O país não pode aceitar isso. Eu já queria aqui também fazer uma convocação a todas as câmaras municipais aqui do nosso país que possam pegar essa moção de repúdio aqui também, assinar, colher assinatura dos vereadores também, e encaminhar para o Supremo, pra lotar a caixa deles de moção de repúdio, para que não aconteça isso no nosso país. A cultura da morte não pode chegar aqui e passa por nós, representantes da população, essa missão. Quando essa casa manda uma nota de repúdio dessa pra lá é a população de Barbacena dizendo que não aceita a cultura da morte. Por isso eu agradeço a todos vocês que assinaram junto conosco essa moção de repúdio e não a morte e sim a vida. Muito obrigado".

O discurso foi disponibilizado em sua rede social na íntegra, transparecendo ganhar mais destaque em relação a vários outros temas dos quais o vereador trabalha e também compartilha na internet. Há na Câmara Municipal de Barbacena uma pequena réplica da bancada evangélica em Brasília ${ }^{12}$, em que o vereador carismático estudado, juntamente com outro vereador evangélico, se unem a partir de temas cujos interesses são semelhantes, a saber, oriundos de setores mais conservadores do cristianismo.

A atuação do vereador estudado, no entanto, não se restringe apenas à temas de cunho religioso. Há projetos relacionados ao tratamento de materiais recicláveis, meio ambiente, saúde, segurança etc. Isso permite sua entrada em outros grupos da sociedade civil organizada que não necessariamente estejam relacionados ao viés da religião, importante estratégia no sentido de alcançar adesão de vários segmentos sociais, possibilitando o sucesso no campo político. Odaci Coradini (1999) e Carlos Procópio (2015) denominam de sistema multiposicional, em que o candidato "lança mão de mais de uma dessas bases de recursos e esferas sociais, de acordo com seu trajeto e inserção social e política e as afinidades possíveis" (Coradini, 1999, p. 14).

Carlos Procópio, ao estudar a candidatura de dois carismáticos no interior paulista, afirma que "Essa adesão muitas vezes se dá para além dos vínculos originais de cada personagem envolvido. Nesse contexto, a busca pela aceitação será um bem perseguido firmemente. Isso leva os candidatos a negociarem dentro de um cenário amplo que envolve a formação de opinião, conquista de voto e veiculação de informação" (Procópio, 2015, p. 208).

Embora em seu primeiro mandato, o vereador carismático demonstra o viés multiposicional, confirmando o compromisso com a base religiosa da RCC, além também de trabalhar em outras frentes sem vinculação específica com a religião.

12 Bancada evangélica é o nome mais conhecido da Frente Parlamentar Evangélica, que reúnem evangélicos e católicos em torno de pautas de cunho moral, sendo o aborto uma delas. 


\section{Considerações finais}

Se nas últimas décadas do século XX os fieis carismáticos eram tidos como alheios à política, atualmente essa ideia não pode mais ser aceita. Atuar na política é, inclusive, compreendido como missão, tornando assim, um espaço reconhecidamente do âmbito profano como algo sagrado. Dessa forma, o acesso a esse campo não é apenas permitido, mas também incentivado e legitimado pela instituição.

Esse fenômeno tem ocorrido em todo o país, não apenas nos grandes centros, mas em cidades menores também, como é o caso de Barbacena, cuja Câmara Municipal conta com a presença de um vereador pertencente à Renovação Carismática. O porte da cidade, portanto, não é levado em consideração para a atuação política.

A participação na política se demonstra, por um lado, acima do espectro partidário. Ou seja, o partido, nessa cado, é tido como meio necessário para pleitear uma vaga no legislativo municipal. Por outro lado, a escolha do partido não é algo aleatório. $\mathrm{O}$ aspecto ideológico se revela na escolha da sigla partidária. Nesse caso, os termos direita e esquerda contribuem para tal escolha. No caso do vereador estudado, o MDB foi o partido escolhido por ser de "centro". Ficam assim, descartados os partidos de esquerda como PT, PSOL, PC do B etc., essencialmente por conta de temas como o aborto, casamento homoafetivo, liberação do uso da maconha.

Embora haja o movimento multiposicional, em que o político religioso busca ampliar suas bases para além do viés da religião, ainda assim prevalece o cuidado redobrado aos temas de cunho moral, influenciado pela ética religiosa, presente nas atuações no âmbito do legislativo, abrindo espaço para o questionamento sobre a condição do Estado laico na relação entre religião e política.

\section{Referências}

CARRANZA, Brenda. Renovação Carismática Católica: origens, mudanças e tendências. 1998. 260 f. Dissertação (Mestrado em Sociologia) - Instituto de Filosofia e Ciências Humanas, Unicamp, Campinas.

CORADINI, Odaci. Em nome de quem? Rio de Janeiro: Relume-Dumará, 1999.

GUIMARÃES, Luiz Ernesto. Teologia da Libertação e Renovação Carismática Católica: religião e política na arquidiocese de Londrina-PR. 2017. 218 f. Tese (Doutorado em Ciências Sociais). Unesp, Marília.

MARIZ, Cecília L. Renovação Carismática Católica: Uma Igreja dentro da igreja? Civitas, v. 3, nº 1, Porto Alegre, jun. 2003, p. 169-186.

MIRANDA, Júlia. Carisma, sociedade e política: novas linguagens do religioso e do político. Rio de Janeiro: Relume Dumará, 1999. 
OLIVEIRA, Pedro A. Ribeiro [et al]. Renovação Carismática Católica: uma análise sociológica, interpretações teológicas. Petrópolis: Vozes, 1978.

PRANDI, Reginaldo. Perto da magia, longe da política: derivações do encantamento no mundo desencantado. Novos Estudos CEBRAP, n 34, nov. 1992, p. 81-91.

. Um sopro do espírito: a renovação conservadora do catolicismo carismático. 2 ed.

São Paulo: Editora da Universidade de São Paulo, 1998.

PROCÓPIO, Carlos Eduardo Pinto. Quando a religião fica perto da política: o caso dos candidatos apoiados pelo catolicismo carismático nas eleições de 2014 no Brasil. Debates do NER, Porto Alegre, ano 16, n. 27, p. 199-232, jan./jun. 2015.

SILVEIRA, Emerson Jose Sena da. Terços, "Santinhos" e Versículos: a relação entre Católicos Carismáticos e a Política. Rever, São Paulo, v. 8, p. 54-74, mar. 2008.

SOFIATI, Flávio Munhoz. Religião e juventude: os novos carismáticos. Aparecida: Ideias \& Letras; São Paulo: Fapesp, 2011.

KUSCHNIR. Karina. Antropologia e política. Revista Brasileira de Ciências Sociais . v. 22, $\mathrm{n}^{\circ} .64$, Junho de 2007, p.163-167. 


\title{
Dando Sentido Ao Mundo Moderno Por Uma Perspectiva Religiosa: Paradigmas estruturais das relações sociais entre establishments de uma comunidade tradicionalista.
}

\author{
Giving Sense To The Modern World For A Religious Perspective: Structural paradigms of \\ social relations between establishments of a traditionalist community.
}

Jéssica Tamires de Paula ${ }^{13}$ jessicatpaula@gmail.com

Vitor César Presoti ${ }^{14}$ vitorcpresoti@gmail.com

Resumo: Da análise apresentada em Os Estabelecidos e os Outsiders, de Norbert Elias e John L. Scotson, pretendemos explorar aspectos das relações de uma comunidade tradicionalista, interligada por duas crenças dicotômicas, mas, essenciais para a permanência dos vínculos sociais. Buscamos presumir como o sentimento religioso transforma e estrutura a coletividade, principalmente, quando este orienta as acepções de mundo na modernidade. Deste ponto, utilizaremos conceitos sobre a modernidade líquida de Zygmunt Bauman e a metáfora marxista de que "tudo que é sólido desmancha no ar", discutida por Marshall Berman para compreender como as transformações que desfazem as relações podem geram uma vida solitária e insegura. $\mathrm{O}$ que não ocorre na comunidade em questão, pois as relações existentes fogem das convicções modernas e se conservam por uma perspectiva que faz sentido e é reproduzida por gerações.

Palavras-Chave: Modernidade. Relações Sociais. Religião. Sentido de Mundo. Tradicionalismo.

\begin{abstract}
From the analysis presented in The Established and the Outsiders by Norbert Elias and John L. Scotson, we intend to explore aspects of the social relations of a traditionalist community, interconnected by two dichotomous beliefs, but essentials for the permanence of interpersonal ties. We seek to presume how the religious sentiment transforms and structures the collectivity, especially when it guides the world's meanings in modernity. From this point on we will use concepts about Zygmunt Bauman's liquid modernity and the marxist metaphor "everything that is solid breaks into the air" discussed by Marshall Berman to understand how the transformations that undo relations can lead to a solitary and insecure life. This is not the case in the community in question, because existing relationships escape modern convictions and are preserved through a perspective that makes sense and is reproduced for generations.
\end{abstract} Keywords: Modernity. Social Relationships.Religion.Sense of World.Traditionalism.

\section{Introdução}

O constante avanço da humanidade e de suas organizações sociais perfazem aspectos que constituem as sociedades pela ordem e desordem, provenientes da modernidade, que manifestam interferência, especificamente, nas relações entre os indivíduos. Visto isto,

\footnotetext{
${ }^{13}$ Graduanda em Ciências Sociais pela Universidade do Estado de Minas Gerais - unidade Barbacena

${ }^{14}$ Graduando em Ciências Sociais pela Universidade do Estado de Minas Gerais - unidade Barbacena
} 
podemos afirmar que tais processos se correlacionam com a metáfora tudo que é sólido desmancha no ar (Marx, 1999)enquanto construção de paradigmas sociais que se desmancham e se destroem, para que possam ser reconstruídos e inovados. Assim, pensemos o mundo moderno enquanto fenômeno que desfaz determinadas convicções e interfere, de forma rápida e eloquente, na sociabilidade (Simmel, 2006) entre os indivíduos da contemporaneidade. Inclusive, interfere, também, nas crenças e nas ações individuais e coletivas (Berman, 2007) enquanto um "ser invisível" que tudo controla (Bauman, 1998) e cujo gerenciamento se estrutura, se organiza e se solidifica de acordo com cada sistema.

Pensando a modernidade enquanto modificadora social de tempo e espaço, se pretende, ao longo deste estudo, apontar aspectos de uma comunidade que foge destas transformações por preceitos particulares, mas que também não exclui a possibilidade de seus habitantes permanecerem em trânsito com os espaços e ideias que não resistiram à este fenômeno. Neste sentido, temos como pressuposto, na primeira sessão, uma discussão sobre quais parâmetros podem sustentar a configuração social de uma comunidade que se encontradistante dos centros urbanizados e mercadológicos, mas que, inevitavelmente, teve sua estrutura comercial e profissional escassa pelas persistentes transformações socioeconômicas e políticas que ocorreram ao longo do tempo. Porém, mesmo com estas constantes mudanças, e pensando a relação entre o global e o local, tentaremos desencadear pontos que fazem com que esta comunidade desenvolva determinados arranjos organizacionais à sua maneira, de forma gradual, e mantendo vínculos e valores, curiosamente, tradicionais, neste mundo moderno.

Além disso, analisando os tipos de relações que existem em sociedades mais complexas, se nota uma característica comum de sempre haver grupos que se revelam proprietários de identidades sociais privilegiadas e se reconhecem como influenciadores e singularizadores de uma tradição a partir da autoridade e da moral (Elias; Scotson, 2000, p. 7,8). Em conjunto com os laços intensos que unem determinados indivíduos enquanto coletivo, se compreendem pressupostos que mantém grupos outsidersdesignados à atributos anômalos e estigmatizados (idem, 2000) que reforçam a condição de outros grupos se caracterizarem enquanto estabelecidos. Pensando nos conceitos elisianos que perfazem as formas organizacionais a partir de fatos que configuram e influenciam inúmeros aspectos da vida grupal, seja no âmbito familiar, entre vizinhos ou "estrangeiros", procuraremos compreender uma comunidade constituída por duas religiões interdependentes, o catolicismo e o espiritismo, passíveis de conflituosidade, em que ambas procuram conquistar e estabelecer 
seu espaço para que possam se manter solidificadas e legitimadas enquanto orientadoras das ações de sua coletividade.

Analisando os relatos dos entrevistados sobre a fundação da localidade e a construção social de dois grupos religiosos desde aquele tempo, compreendemos os espíritas enquanto outsiders, uma vez que os discursos nos levam a entendê-los enquanto reivindicadores de espaço para que suas práticas religiosas entre os católicos pudessem se tornar permitidas, possíveis e plenas por seus descendentes:

Entrevistado (a): Os pioneiros, que eu falo da doutrina espírita aqui... Todos já morreram, né?! Então... Eles tiveram uma luta, né?! Não foi fácil para eles, não! Eles tiveram uma luta grande mesmo! Alguns com a própria família, outros com a comunidade mesmo... Mas é igual eu te falei, foram batalhando e batalhando, e foram vencendo até que manteve que certa ordem. Não vou te dizer que todos os católicos aqui tem uma visão da doutrina espírita, do espiritismo aqui, assim, como se diz, aceitam muito, mas também não desrespeitam... Mas os pioneiros tiveram uma luta bem grande. Lutaram e venceram.

Como podemos notar no trecho recortado de uma de nossas entrevistas, atualmente, o conflito foi substituído por respeito e tolerância. Neste ponto, o que tudo nos indica é que esta aceitação entre ambas as religiões pode ser pensada enquanto intenção inconsciente de conduta a partir de representações de papéis (Goffmann, 2014) necessária para a aproximação e permanência do trânsito social enquanto configuração de uma sociabilidade (Simmel, 2006) permitida em seu contexto.Pensando a discussão sobre a necessidade e permanência da sociabilidade, inclusive, tendo o conflito como seu fator essencial enquanto processo de construção de identidade do indivíduo, aprofundaremos, na segunda sessão, questões sobre a inserção do ser humano em contextos e grupos que lhe dão significações do mundo social e são essenciais para o convívio coletivo.

Por hora, caracterizaremos esta peculiar comunidade de que tanto falamos enquanto uma localidade interiorizada dos centros urbanos, na qual foi fundada por imigrantes italianos em meados do século XX e teve sua principal atividade voltada para a agricultura. Atualmente, ela é constituída por poucomenos de 1000 habitantes e passou por uma reestruturação econômica, se adaptando aos meios citadinos. Hoje, os habitantes se mantêm unidos pelo sentimento de reciprocidade e respeito, orientados pelas instituições religiosas supracitas, que, agregadas aos valores familiares, são essenciais para a manutenção dos vínculos interpessoais.

Em vista disto, se compreende que os laços entre esteshabitantes fogem de quaisquer aspectos de distanciamento ou de transformações de valores e concepções. Nota-se que naquele espaço social ainda existe uma aproximação entre seus semelhantes, na qual se 
mantém por uma harmonia que parte do sentimento de solidariedade proveniente das explicações divinas e de valores familiares, mantidos, organizados e estabelecidos por cada um dos indivíduos que, nesta comunidade, reside.

Portanto, será a partir destes pontos fundamentais que constituem nosso objeto de análise que procuraremos apontar, na terceira sessão, aspectos que dão sentido ao mundo para esta comunidade a partir das duas religiões ali existentes. Porém, nossas pontuações não se voltarão para as características de cada uma delas, pois nosso intuito partirá, principalmente, de como tais religiões, em suas especificidades, perfazem as explicações e orientações de cada crença neste mundo moderno. Assim, tendo esta comunidade constituída por uma estrutura de interdependência entre grupos que reivindicam cada um à sua maneira, espaços e direitos de exercerem suas atividades de forma autônoma e plena, o que não exclui a presença de conflitos, se percebe que os grupos outsiders, a priore, vão se modificando e fazendo com que os moradores mantenham distanciamento de "estrangeiros", uma vez que eles, caso não possuam nenhum grau de parentesco com os habitantes, devem se adaptar às atividades de acordo com a organização social e religiosa da comunidade.

Dadas tais pontuações, pretendemos, nas considerações finais, delimitar quais aspectos perfazem as questões enquanto justificativas de mundo e como seu envolvimento, desenvolvimento e renovação permitem reflexões sobre sua essencialidade para a manutenção de preceitos sociais e religiosos que predeterminam e caracterizam relações baseadas na harmonia e na assistência mútua entre estabelecidos e "forasteiros" desta peculiar comunidade analisada.

\section{Metodologia}

No âmbito metodológico, nossa produção se baseia na história oral e na utilização da memória enquanto fonte de pesquisa, tendo o objetivo de analisar as (re) significações que os habitantes da comunidade analisada reproduzem e perpetuam ao longo do tempo e entre as gerações, uma vez que tais lembranças os identificam e os interpretam enquanto atores sociais, pois:

[...] a história oral pode dar grande contribuição para o resgate da memória nacional, mostrando-se um método bastante promissor para a realização de pesquisa em diferentes áreas. É preciso preservar a memória física e espacial, como também descobrir e valorizar a memória do homem. A memória de um pode ser a memória de muitos, possibilitando a evidência dos fatos coletivos (THOMPSON, 1992. p. 17). 
E por ser acrescentada às novas perspectivas historiográficas, inclusive, se interligada à análise de documentos diversos, a história oral centra-se na memória humana em sua capacidade de rememorar o passado enquanto testemunho vivo de algum acontecimento, colocando sua presença pela construção psíquica compreendida por um filtro em uma totalidade e, logo, selecionada de acordo com aquilo que o indivíduo quer lembrar e colocar ao público. O que também não podemos deixar de considerar é que a memória e a imaginação guardam certa semelhança quando influenciadas e ressignificadas por intermédio do meio externo, seja pela música, pela poesia e etc. (Matos, Senna, 2011).

Portanto, a memória é sempre uma construção feita no presente a partir de vivências ocorridas no passado. Memórias individuais e coletivas se confundem [e por isso] estamos sujeitos a influências [de grupos que] pertencemos e com os quais nos identificamos (MATOS, SENNA, 2011. p 97).

Assim, a memória se faz constituída por elementos perceptivos do "eu" e do "outro", evocando circunstâncias e eventos de forma que sejam traçados, contornados e reconstruídos pela rememoração (Halbwachs, 1990) dos agentes. Neste sentido, nosso princípio parte de uma postura que "contribui para a compreensão da especificidade e singularidade dos grupos sociais em diferentes épocas” (Schmidt; Mahfoud, 1993), “dando voz” a estes indivíduos e acessando suas memórias em um processo de indagação e despertar das acepções de determinados períodos de suas vidas, sejam elas individuais e/ou coletivas, no passado e/ou no presente.

Deste ponto, compreenderemos como estes moradores se organizam e se interagem de acordo com os códigos estabelecidos e a constituição dos espaços e bens simbólicos ali existentes (Bourdieu, 1989).

A coleta de dados por meio da históriaoral e a memória enquanto fonte de pesquisa só pôde ser concebida a partir de entrevistas semiestruturadas, que foram realizadas com líderes políticos e leigos religiosos, e junto ao levantamento e organizações de documentos sobre a comunidade foram, posteriormente, transcritas, analisadas, e quando necessário, passaram por uma reformulação do roteiro e das perguntas. Logo, tanto as transcrições quanto as produções baseadas nas informações coletadas, são apresentadas para fins acadêmicos e também, para arquivamento.

Partindo deste pressuposto, se pretende utilizar tais fontes a fim de analisarmos o campo social e religioso desta comunidade tradicionalista que ainda perpetua aspectos muito 
particulares e, deste modo, contribuiremos para discussões e trabalhos acadêmicos sobre a relação entre os temas voltados para a sociedade e para a religião.

\section{1) O Processo Da Modernidade}

Detenhamo-nos, por um momento, no processo de desenvolvimento do ser humano enquanto dono de suas ações e de seus preceitos provenientes da modernidade. Deste ponto, podemos notar que a sociabilidade (Simmel, 2006) entre os indivíduos se transformam e se tornam instantâneas à medida que se domina as coisas pela racionalidade e se possibilita um mundo repleto de grandes possibilidades e potenciais. Porém, este êxito sobre as coisas não se mantém suficiente e estático, pois, é neste mesmo momento, que o indivíduo se vê diante de um completo sentimento de mal-estar, categorizado por uma civilização moderna e urbanizado aos moldes de sociedades ideais, tornando seus sujeitos perseguidores de uma felicidade pura e plena, mas inalcançável (Freud, 1996).

O desenvolvimento humano pode ser pensando desde a ideia iluminista de que o indivíduo atinge uma razão transcendental para se criar um ser humano perfeito, orientado, pronto e capaz de guiar todas as suas ações no mundo pela lógica da razão pura (Kant, 1980). Porém, isto não exclui a possibilidade de que este mesmo indivíduo, dono de seu caminho, esteja amarrado a uma falta que pode ser representada e estabelecida por normas, regras, privilégios e status, ambos oferecidos pelas instituições sociais modernas (Freud, 1996).

A sistematização das ações individuais e coletivas através de corporações perfaz um controle dos indivíduos por intermédio de instituições estruturadas e estruturantes que apresentam uma lógica universal de manutenção e esclarecimento da realidade através de simbologias que instrumentam a integração social (Bourdieu, 1989). Neste sentido, as concepções já estruturadas, e que dão sentido ao mundo, são reproduzidas de acordo com uma ordem social e moral que legitimam e distinguem culturas, crenças e paradigmas estruturais (idem, 1989). Neste caso, algumas delas fornecem o refúgio, representam a paz e o sentimento de pertencer a determinados agrupamentos.

Por isso, este indivíduo se mantém ligado a uma falta desde sua constituição enquanto ser humano, na qual este se orienta e se representa por instituições estruturadas e estruturantes que perfazem uma lógica universal de manutenção e esclarecimento da realidade através de símbolos que instrumentam o sentido de mundo e cuja constituição e condicionamento estão presentes na reprodução de uma ordem social e moral que legitimam e distinguem culturas, crenças e paradigmas estruturais (Bourdieu, 1989). 
Aliás, seguindo a lógica do capitalismo também ser causador da infelicidade - mas que, dicotomicamente, permite um desenvolvimento pleno de riquezas -, todos os prazeres e outros quaisquer aspectos culturais do ser humano são distintos, selecionados e dominados por mecanismos que perfazem um modelo de abstração da sociedade, constantemente, ressignificada e avaliada a partir do status que mais importa ao indivíduo no complexo processo sociopolítico e econômico (Marx, 1988) no qual ele está inserido. Em consequência disso, a sociedade se reconstrói por uma série de estruturas que aprisionam as ações do ser humano para que elas não se manifestem de maneira plena, mantendo-o preso aos seus instintos e vinculando-o às coisas simbólicas, abstrações e valores criados pela modernidade, elaborados pelas próprias relações sociais e estruturados por instituições que constroem figurações para cada tipo (ou classe) de indivíduo e/ou agrupamentos sociais (idem, 1988).

Deste ponto, destacamos, também, que as inovações sociais nos costumes, por exemplo, transformam a lógica de organização que se processam quando algo, já estabelecido, é alterado, modificado ou destruído e que, portanto, se compreende que a ideia de estabilidade não existe, pois a modernidade é instável, caótica e obsoleta (Berman, 2007).

Entretanto, pressupondo que as mudanças e a globalização alcançam qualquer espaço, vale destacar que na pequena comunidade estudada existe um arraigado apego aos espaços, demarcados, principalmente, por duas religiões que mantém a proximidade entre os indivíduos e valores familiares, nos quais, ao contrário do arranjo moderno e transformador da vida em sociedade, sua configuração é mantida por vínculos reproduzidos e eternizados por gerações.

\section{2) A Representação De Papéis Entre As Relações Sociais}

A interação humana pode ser definida por representações sociais nas quais seus papéis são influenciados por decisões de um senso comum que não dependem de uma teorização de conceitos e reflexões que apontem para a desnaturalização das coisas, e que muitas vezes, podem entrar em desacordo com a totalidade (Goffmann, 2014).

Deste modo, se supõe que a harmonização e a organização religiosa que se estruturam em um possível conjunto de representação de papéis na comunidade de nosso estudo, podem estar condicionadas a atores vinculados a grupos posicionados de acordo com preceitos inerentes a eles (Houtart, 1994 apud Liberal, 2004) e que inserem o indivíduo em determinadas instituições, inclusive, religiosas, pois esta: 
[...] possui várias funções relativas às representações, às expressões, à ética e à própria organização. [...] Em relação à representação dos conhecimentos, além da transmissão do que já existente, a organização religiosa pode também produzir novos sentidos religiosos, em novas circunstâncias [...] (LIBERAL, 2004, p. 7,8).

E, portanto, elas se tornam base para a reprodução e sustentação do convívio coletivo de sociedades baseadas em preceitos tradicionais, como os familiares, por exemplo, evidenciando uma fachada de ações e mutualidades entre os moradores de diferentes crenças e cujo sentido de mundo parte da sociabilidade e interferência da religião e da família na vida cotidiana dos indivíduos.

Neste contexto, compreendemos nossa comunidade de estudo como um ambiente passível de conflitos, uma vez que esta se constitui por uma série de convicções para se pensar e se entender o mundo pelo viés de duas crenças distintas e interdependentes, organizadas e estabelecidas por formas de poder e manutenção de modelos tradicionais de família, reciprocidade e conservação de uma fachada harmônica, através do papel que cada indivíduo, ou coletividade, representa em sua configuração social.

Entretanto, destacamos que não são todos os âmbitos estruturais desta comunidade que se encontram tradicionalistas. Se analisarmos, de forma particular, que alguns grupos ou atividades não estão organizados de forma tão convencional assim como,por exemplo,a economia desta sociedade não se basearda subsistência voltada para agricultura; ou, também, quando notamos que algumas famílias não são compostas com uma grande quantidade de filhos. Além disso, as pessoas que precisam se locomover por causa de trabalho, de estudo, de atividades religiosas, ou por quaisquer outros motivos, acabam trafegando sentimentos, pensamentos e ideias, transmitidos pelo simples contato com o espaço de grande movimento urbano e social, desfazendo seu isolamento total. Assim, toda a estrutura, seja ela social, familiar e coletiva, se moldam às transformações externas, às demandas contemporâneas e ao desenvolvimento da humanidade.

No que concerne à existência de conflitos, compreendemos que estes são admitidos enquanto formas de sociação e podem ser destinados a resolver dualismos, inclusive, levando à aniquilação de uma das partes contestadas ou resolvendo tensões entre agrupamentos com pensamentos divergentes (Simmel, 2011). Neste sentido, seu caráter se torna "positivo", uma vez que assimilamos este fenômeno enquanto processo normal e institucionalizado pela sociedade moderna; além disso, sua relevância parte de uma lógica harmônica que perfaz a criação da personalidade através da religião ou da ética, em que ambas operam na existência social e no constante processo de concretização de vida (idem, 2011). Partindo deste pressuposto, a sociedade está determinada por uma razão quantitativa de tendências 
favoráveis e adversas, pois ela é considerada produto de categorias interacionistas que se manifestam, de forma positiva, mesmo a partir de tensões nas relações mais particulares e interiores (idem, 2011).

Portanto, compreenderemos as interações sociais existentes na comunidade analisada a partir de aspectos sobre quais interesses individuais mútuos são capazes de interferir na totalidade de determinado agrupamento, inclusive, se houver uma dialogicidade que intervenha na convivência dos indivíduos a partir de uma unidade comum que impulsiona, destina, interessa e tende a condicionar cada movimento social e suas percepções de mundo, assim como seus efeitos (Simmel, 2006). Portanto, essa sociação transforma as formas de pertencimento, de forma geral, em aspectos sensoriais, conscientes e duradouros de sociabilidade, cuja base está solidificada no desenvolvimento das sociedades humanas (idem, 2006). Assim, as significações da existência e interpretações da realidade necessitam de propósitos que possam organizar o emaranhado de exigências e dinâmicas sociais, e legitimar as instâncias superiores e extrínsecas das formas de comportamento que o uso desta sociabilidade assume (idem, 2006). Com isso, seu sentido dá força e determina as interações mútuas construídas de uma unidade similar que delimita as inter-relações conscientes atribuídas, de forma pura, à cooperação e à coalizão de determinadas formas sociais singulares de um espaço limitado, autônomo e autêntico à sua maneira (idem, 2006).

Continuando na ótica simmeliana sobre o conflito enquanto forma de promover a interação entre os indivíduos, partimos deste ponto, com Norbert Elias e John L. Scotson (2000), nos quais se preocupam com as relações sociais intergrupais, independentemente, de sua característica estrutural, quando estes desenvolvem um estudo sobre uma comunidade permeada por relações de poder enquanto produção do status de grupos estabelecidos ou outsiders. A partir de alguns estudos sobre sua obra, destacamos que:

\footnotetext{
Na contramão do pensamento hegemônico do estrutural-funcionalismo de que a sociedade se organiza tal qual organismos com estruturas e funções sociais regidas por atributos coercitivos com a forma de orientação do comportamento dos indivíduos, [Norbert Elias; John L. Scotson (2000)] adota como metodologia de pesquisa a noção de interdependência entre os indivíduos, cujo aporte se sustenta na perspectiva de que tal ligação origina configurações de diversas instituições que relacionadas imbricam numa teia de interdependência da sociedade (MARTINS, 2012, p. 108).
}

Como é o caso de nossa comunidade, na qual preserva delimitações estruturais organizadas, conquistadas e já estabelecidas desde a sua gênese, fundamentada por valores de família e por duas religiões, que dão sentido ao mundo dos indivíduos ali inseridos, sustentando o sentimento de tolerância, reciprocidade, respeito e harmonia entre os habitantes. 
Dito isto, "a democracia da sociabilidade, mesmo entre aqueles socialmente iguais, é um jogo de cena. A sociabilidade cria, caso se queira, um mundo sociologicamente ideal" (Simmel, 2006, p. 69). Neste ponto, compreendemos esta comunidade como interdependente, mas que, outrora, não viabiliza vicissitudes da presença de demais doutrinas religiosas, pois caso existam, permanecem inacessíveis.Portanto, destacamos que sua peculiaridade se constitui por características oriundas de sentimentos religiosos e pela perpetuação de valores interfamiliares.

Além disso, mesmo que, atualmente, exista uma espécie de harmonia entre os moradores, compreendemos os discursos sobre os tempos primórdios da fundação da localidade, enquanto deslegitimação das atividades do grupo tido como outsider, os espíritas. Entretanto, a constituição deste espaço social e de seus agrupamentos distintos se mantém pelo apoio mútuo, justificado pela orientação divina, propagada por líderes religiosos e pelos valores tradicionais que compõem a maioria das famílias residentes neste agrupamento social. Assim, esta estrutura de solidariedade parte de fundamentos de compatibilidade com a finalidade de desenvolver a sociabilidade no meio coletivo que possa impulsionar e cultivar as relações em diversas circunstâncias individuais ou intergrupais, uma vez que a estrutura religiosa e familiar, neste caso, se compreende pela harmonia entre os indivíduos que compõem aquele contexto social.

\section{3) Religião E Sentido De Mundo}

Desde a formação das sociedades enquanto produto do indivíduo, compreendemos uma exteriorização do ser humano sobre o mundo; a objetivação enquanto conquista dos produtos provenientes desta efusão; e a interiorização que perfaz uma reapropriação subjetiva da realidade por parte dos indivíduos. Ou seja, o ser humano produz o mundo a partir dele mesmo, se estabelece e realiza sua vida pela produção de instrumentos que modificam o ambiente físico, a natureza, a linguagem e os elementos simbólicos que transpõem os aspectos de convivência (Berger, 1985). Neste sentido, não podemos analisar o indivíduo de forma particular em relação ao seu mundo, uma vez que a construção humana será sempre social, pois juntos, os indivíduos fabricam instrumentos, inventam línguas, aderem valores, concebem instituições e um conjunto de produtos culturais produzidos e reconhecidos por eles mesmos em sua coletividade (idem, 1985).

Pensando na sociologia de Erving Goffmann (2014) e sua compreensão sobre a adequação dos valores por meio de uma "fachada" e pela representação de papéis, nos quais 
os indivíduos se inserem e se expressam de forma intencional e inconsciente enquanto código de conduta para a reprodução e permanência de um convívio social e coletivo harmônico, se compreende a configuração de uma instituição familiar, por exemplo, a partir de como cada integrante mantém sua representação de acordo com o que foi estabelecido enquanto modelo de comportamento individual, apreendendo, assim, sua própria identidade no mundo objetivo (Berger, 1985). Ora, viver no mundo social é viver uma vida significativa, presumindo que a sociedade é guardiã da ordem e do sentido das estruturas institucionais e da estruturação da consciência coletiva (idem, 1985).

Longe disso, caso haja uma separação entre o homem e o mundo social, surge, então, uma ameaça em razão da perda do senso da realidade, dos laços que possam dar sentido ao mundo, e das posturas morais com consequências psicológicas e cognitivas, seja pela perda de status, pelo divórcio, pela morte, ou pela separação física (Berger, 1985). Portanto, no meio deste "caos", a sociedade tende a desenvolver mecanismos que orientam seus membros para uma realidade que sai da anomia e conserva os limites seguros do nomos estabelecido, dando sentido à ordem social de forma desejável, correta e inevitável; o que pressupõe um terror social que é pensando de forma apreensiva e na qual sua prática pode ser alimentada, $a$ posteriori, pelo remorso de consciência - controle dos instintos individuais e coletivos (idem, 1985). Portanto, “os programas institucionais são dotados de um status ontológico a tal ponto que negá-los equivale negar o próprio ser” (Berger, 1985, p. 37).

E para que a vida humana fuja do caos e do terror, a sociedade, ou melhor, o próprio indivíduo, dota sua vida de sentido e de sanções pautados na ordem, e no caráter, e reafirmados através de ritos que fornecem um escudo sagrado contra a "ameaça" exterior ao sua prática metódica; ora, “(..) A religião é o empreendimento humano pelo qual se estabelece o cosmos sagrado [enquanto] qualidade de poder misterioso e temeroso, distinto do homem e todavia relacionado com ele" (Berger, 1985, p. 38). Portanto, se compreende a religião enquanto produto do ser humano que para controlar seus instintos, a cria para dar significação ao seu mundo de forma particular e coletivo, fundamentando-a, estrategicamente, de forma a estruturar, fundamentar, construir e infundir a realidade pela concepção de um universo, humanamente, significativo (idem, 1985).

Neste sentido, retornemos aos conceitos freudianos, quando assimilamos um indivíduo que, a priore, tinha divindades como referência para o sentido da vida, se torna o "deus" da própria espécie quando este passa a desenvolver tecnologias e recursos ao longo do tempo/espaço histórico de acordo como a transformação da ordem de convivência social e do próprio juízo da humanidade, criados pelo conhecimento científico e atrelado à ideia da razão 
(Freud, 1996). Entretanto, podemos entender que os indivíduos em sociedade não se encontram aptos a absorver as mudanças modernas e, por isso, precisam aprender a se desenvolver e perpetuar sua ordenação, preceitos e valores nas relações sociais, pois, caso eles não se adaptem, se "desmancharão" assim como todas as tradições que se perdem ao longo do tempo (Bauman, 1998). Portanto, esta perspectiva nos permite uma reflexão de como a ordem se reconfigura socioeconomicamente, politicamente e/ou profissionalmente, e mantém as sociedades organizadas dentro de convicções modernas e padronizadas enquanto garantia para o não isolamento da globalização e da inovação.

A religião pensada enquanto teoria criada pelos seres humanos para dar sentido ao mundo e cuja essência se pauta na subjetividade e no relativismo (Sartre, 2005), se constrói através do tempo e se responsabiliza em direcionar as relações sociais pelo investimento de um modelo central - a divindade - que sintetiza tudo aquilo que o homem precisa ter e ser enquanto vive (Iturra, 1991). Neste sentido, pensemos a religião enquanto um sistema estruturado em simbolismos, que assume uma função prática e ideológica a fim de suprir e reforçar a legitimação de tudo que possa ser definido, socialmente, entre um grupo ou uma classe (Bourdieu, 2011).

[...] Se a religião cumpre funções sociais, tornando-se, portanto, passível de análise sociológica, tal se deve ao fato de que os leigos não esperam da religião apenas justificações de existir apenas capazes de livrá-los da angústia existencial da contingência e da solidão, da miséria biológica, da doença, do sofrimento ou da morte. Contam com ela para que lhes forneça justificações de existir em uma posição social determinada, em suma, de existir como de fato existem, ou seja, com todas as propriedades que lhes são socialmente inerentes (BOURDIEU, 2011, p. 48).

Pensando em tais justificações que constituem as organizações e interações sociais, pensemos, por um momento, no constante processo de desenvolvimento estrutural moderno das sociedades que perfazem pluralidades suscetíveis aos conflitos e à intolerância por parte da não aceitação dos tipos de verdades, sejam elas semelhantes ou distintas, inclusive, no contexto religioso. E como já compreendido, na comunidade analisada não seria diferente. Deste ponto, analisamos alguns estudos que apontam que há uma disputa de bens simbólicos (Bourdieu, 1989), inclusive, pela Igreja Católica, uma vez que ela reivindica "a legitimidade de seus dogmas e doutrina desqualificando o espiritismo, demonstrando receio de que a doutrina de Kardec se dissipasse e que fiéis católicos enveredassem para [ele]" (Machado, 2014, p. 67). Da mesma maneira, podemos pensar em tais disputas de campos e poder simbólicos, quando se trata, principalmente, sobre demais religiões como de matriz africana, islâmica e etc. 
Adjacente a isso, neste contexto, e mesmo pela aparente harmonia e reciprocidade entre os moradores desta pequena comunidade, vale salientar que esta "fachada" não exclui uma resistência em aceitar quaisquer interferências e expansões imediatas advindas do âmbito global, social ou religioso, uma vez que não encontramos vestígios de outras crenças "não tradicionais", aceitação de mudanças territoriais e/ou de habitantes, nos quais são controlados pelos próprios descendentes dos fundadores da localidade.

\section{6) Considerações Finais}

Partindo da modernidade enquanto processo desmantelador que transforma as organizações sociais, e tudo à sua volta, a partir de um preceito de que tudo deve se adaptar às suas formas e prescrições, podemos notar que este fenômeno não se aplica de modo prematuro na comunidade em destaque. A superficialidade se desloca para o exterior e as relações em seu interior se consolidam na medida em que as informações e características notórias deste agrupamento demonstram como os moradores recebem e percebem qualquer tipo de transformação social, inclusive, por uma perspectiva religiosa e familiar.

Compreende-se que a religião, neste caso, é o elemento estruturado e estruturante desta comunidade, uma vez que as tradições são preservadas e perpetuadas pelos laços religiosos nos quais também compõem as famílias e suas interdependências estruturais e sociais. Além disso, o sentido de mundo orientado e constituído pela perspectiva religiosa constrói valores morais que se justificam pela religião e também são mantidas conforme as regras e normas institucionalizadas.

Pensemos a família enquanto base para a estruturação social, na qual é aplicada no estudo em Winston Parva, uma localidade fictícia criada por Elias e Scotson (2000), de modo que eles possam discutir sobre como as unidades familiares dependem de relações extrafamiliares, com vizinhos e com a comunidade, para se desenvolverem e se perpetuarem, uma vez que este fenômeno também está arraigado na comunidade analisada quando percebemos que as estruturas familiares daquele local se conectam por laços de vizinhança e de parentesco. Em alguns relatos, notamos tal proximidade entre os habitantes dali, por exemplo, quando analisamos em uma de nossas entrevistas que, questionada sobre o convívio "harmônico" da comunidade com os moradores vindos de fora em atividades coletivas, uma descendente dos fundadores, e espírita, destaca que: 
Entrevistado (a):Aqui [...] a raiz mesmo geral é tudo família. Se você for olhar, é tudo parente de parente (risos), né?! Eu falo com muita gente que eu sou casada com o irmão da minha cunhada e ela vice-versa (risos). [...] É tudo assim, né?!

Portanto, hipoteticamente, esta comunidade está solidificada a partir da uma estruturação de laços entre a vizinhança de forma significativa para mantê-la a configuração social que perfaz a família e comunidade enquanto entidades interdependentes e tradicionais, sustentados e fortalecidos pela referência dos membros que compõem o espaço familiar, e mediando as interações sociais pela religião que ali se ampliou e se preservou.

Deste modo, mesmo que existam grupos estabelecidos que, em tempos primórdios da fundação da comunidade apresentada ao longo desta discussão, tenham dificultado a existência de outros grupos outsiders, inclusive, religiosos que, constantemente, reivindicam o direito de manifestar suas formas de pensar, seus preceitos, seus valores e suas ações, compreendemos que as orientações inerentes destas doutrinas tentam se adaptar ao desenvolvimento socioeconômico e cultural que estão alicerçados aos fenômenos que intercedem às relações sociais, indo além de conflitos ideológicos. Assim, é a partir da religiosidade e da rede de parentesco que traz tranquilidade e segurança, que a reciprocidade fundamenta, inclusive através de discursos com a finalidade de corporificar e manter um convívio coletivo que perpassa a lógica da impulsiva e urgente corrida para se alcançar a felicidade.

O que nos interessa a partir de tais suposições é entender o que mantém a existência de uma comunidade tradicionalista, quando se compreendem determinados grupos que mantém seus familiares próximos aos núcleos patriarcais, por exemplo, ou quando os indivíduos explicam quaisquer divergências e contratemos através da orientação religiosa e familiar, se mantendo unidos, independentemente, da crença. Outro fator é buscar por quais aspectos uma rede familiar comporta e permite uma heterogeneidade religiosa, uma vez que se percebem institucionais sendo constituídas por atores de religiões diferentes, mas que em alguns casos analisados, as próximas gerações acabam por seguir o patriarcado, inclusive, sendo introduzidas nas atividades organizacionais do espaço religioso.

Mas quais fatores estimulam e condicionam esta lógica patriarcal em plena modernidade? A priori, destacaremos que o sentido de mundo é, predominantemente, explicado por verdades religiosas, e o tradicionalismo desta comunidade também se mantém pautado e estruturado pela religião em um contexto que foge das transformações, se mantendo em um ritmo particular, inclusive, no que concerne ao acolhimento daqueles "vindos de fora". 


\section{Referências bibliográficas:}

BAUMAN, Z. Modernidade e Holocausto. Rio de Janeiro: Zahar, 1998.

BERGER, P. L. O Dossel Sagrado: elementos para uma teoria sociológica da religião. São Paulo: Editora Paulinas, 1985.

BERMAN, M. Tudo o Que é Sólido Desmancha o Ar: A Aventura da Modernidade. São Paulo: Cia das Letras, 2007.

BOUDIEU, P. O Poder Simbólico. Rio de Janeiro: Bertrand, 1989.

BOURDIEU, P. A Economia das Trocas Simbólicas. $7^{\mathrm{a}}$ edição. São Paulo: Perspectiva: 2011.

ELIAS, N.; SCOTSON, J. L. Os Estabelecidos e os Outsiders. Jorge Zahar Editora Ltda.: Rio de Janeiro, 2000.

FREUD, S. O Mal-estar da Civilização. Edição Standard Brasileira das Obras Completas de Sigmund Freud. Vol. 21. Rio de Janeiro: Imago, 1996.

GOFFMAN, E. A Representação do Eu na Vida Cotidiana. Petrópolis: Vozes, 2014.

HALBWACHS, M. A Memória Coletiva. São Paulo: Editora Revista dos Tribunais Ltda, 1990.

HOUTART, F. Sociologia da Religião. São Paulo: Editora Ática, 1994.

ITURRA, R.A religião como Teoria da Reprodução Social: Ensaios de Antropologia Social Sobre Religião, Pecado, Celibato e Casamento. Lisboa: Editora Fim de século, 1991.

KANT, I. Crítica da Razão Pura. São Paulo: Abril Cultural, 1980 (Os pensadores).

LIBERAL, M. M. C. de. Religião, identidade e Sentido de Pertencimento. Coimbra: VIII Congresso Luso-Afro-Brasileiro de Ciências Sociais: A Questão Social no Novo Milênio, 2014 [online] Disponível em https://www.ces.uc.pt/lab2004/pdfs/MarciadeLiberal.pdf Acesso em 11 de novembro e 2018 às $15 \mathrm{~h} 55 \mathrm{~m}$.

MACHADO, M. Disputas Simbólicas entre Católicos e Espíritas no Primeiro Centenário do Espiritismo. Oficina do Historiador. Porto Alegre: EDIPUCRS. Volume 07. Número 02. pp. $62-79$, jul/dez 2014.

MARTINS, L. G. "Os estabelecidos e os outsiders" - Um convite para repensar heranças histórico-sociológicas. Revista Simbiótica Universidade Federal do Espírito Santo / Núcleo de Estudos e Pesquisas Indiciárias / Departamento de Ciências Sociais ES: Volume único.

Número 01, junho/2012. [online] Disponível em http://periodicos.ufes.br/simbiotica/article/view/4516/3520 - Acesso em 04 de novembro de 2018 às $16 h 29 m$.

MARX, K. O Capital. Vol. 2. $3^{\text {a }}$ edição. São Paulo: Nova Cultural, 1988.

MARX, K.; ENGELS, F. Manifesto do Partido Comunista. $9^{\text {a }}$ edição. Petrópolis, RJ: Vozes, 1999.

MATOS, J. S.; SENNA, A. K. de. História Oral como Fonte: Problemas e Métodos. Historiæ, Rio Grande, 2 (1): 95-108, 2011.

SARTRE, J. P. O Ser e o Nada: Ensaio de Ontologia Fenomenológica. 13 ${ }^{\text {a }}$ edição. Petrópolis: Vozes, 2005.

SCHMIDT, M. L. S.; MAHFOUD, M. Halbwachs: Memória Coletiva e Experiência. Revista Psicologia USP: Volume 4. Número 1 - 2. São Paulo. p. 185 298, 1993.

SIMMEL, G. O Conflito como Sociação. Revista Brasileira de Sociologia da Emoção: Volume 10. Número 30. (1964), 2011.

SIMMEL, G. Questões Fundamentais da Sociologia - Indivíduo e Sociedade. Rio de Janeiro: Jorge Zahar Editor Ltda., 2006.

THOMPSON, Paul. A voz do passado. São Paulo: Paz e Terra, 1992. 


\title{
Biopolítica e o uso dos corpos no dispositivo cristão
}

\author{
Biopolitics and the use of the bodies in the Christian apparatus
}

Mauro Rocha Baptista ${ }^{15}$

mauro.baptista@uemg.br

Resumo: No cenário recente o termo biopolítica tem se apresentado como um importante aporte para análise da conjuntura sócio-política. O conceito é usado por Giorgio Agamben para pensar a forma como os dispositivos aprisionam a vida das pessoas e conduzem a um uso específico dos corpos. Esse domínio sobre a vida e o corpo dos cidadãos está prenhe das ideologias do dispositivo cristão sobre a forma adequada de se portar no espaço público, é esta a relação que pretendemos explorar nesta apresentação.

Palavras-chave:Biopolítica. Giorgio Agamben. Dispositivo.

Abstract: In the recent scenery the term biopolitics has been contributing to the analysis of the social political conjecture. This concept is used by Giorgio Agamben to think how the apparatus imprison people's lives and conduct to a specific use of the bodies. This dominance of the citizens' lives and bodies is filled with the Christian apparatus's ideologies about the appropriate behavior in public spaces, and this is the relation that we are going to explore on this presentation.

Keywords: Biopolitics. Giorgio Agamben. Apparatus.

\section{Introdução}

O conceito de biopolítica tem adquirido relevância, ao menos a partir de Michel Foucault, como um instrumento bastante útil na compreensão dos contextos políticos contemporâneos. O termo já é utilizado entre positivistas a partir de 1900 "para indicar o estágio de autodisciplina natural dos animais, capazes de adesão espontânea à norma e aos fins da vida, para a final sociocracia especificamente humana" (Bazzicalupo, 2017, p. 22). Nestas primeiras formulações existe uma associação maior com o mundo da vida animal, ainda não direcionada para a qualificação da vida humana, que seria, em contrapartida, um estágio mais evoluído dessa disposição normatizante. Todos os animais se sujeitam, por sua estrutura biológica, a uma vida organizada politicamente. Os seres humanos, em especial, por uma necessidade de conviver em sociedade.

\footnotetext{
${ }^{15}$ Doutor (2009) em Ciência da Religião pela Universidade Federal de Juiz de Fora. Professor vinculado ao Departamento "Ciências Humanas" da Universidade do Estado de Minas Gerais-UEMG e ao Ensino Religioso na Escola Estadual Adelaide Bias Fortes.
} 
Se os primeiros momentos da biopolítica estão associados à obediência, um segundo passo a ser destacado se manifesta para a compreensão da desobediência. Na década de 1970 nos Estados Unidos da América iniciam-se uma série de estudos de cunho farmacológicos e comportamentalistas, visando o controle das dissidências comportamentais.

É relevante atentar para o momento em que surge, pois a década de 1970 é um período no qual se delineiam comportamentos políticos que fogem às definições e sanções dos dispositivos jurídicos modernos, irredutíveis à motivação da escolha racional e não completamente condicionados pela cultura dominante (Bazzicalupo, 2017 , p. 25).

O não aceite da cultura dominante, a não adesão espontânea às normas, o inverso das constatações positivistas a respeito da politização da vida, fazem com que os estudos sobre biopolítica ganhem um novo fôlego. A década de 1970 apresenta os movimentos sociais que simplesmente não querem se vincular à norma predominante. Uma conduta sexual destoante da moralidade tradicional, um uso de drogas com a finalidade de descoberta de outras possibilidades de percepção, e não apenas para recreação ou entorpecimento, uma sonoridade musical que desperta para o confronto. Uma posição que sabe muito mais "aquilo que não se é" do que "o que se é" efetivamente.

O conceito de biopolítica, tomado a partir dessa segunda compreensão, será retrabalhado por Michel Foucault em uma relação com o dispositivo cristão do pastorado, assumindo a partir dessa revisão o formato que tende a ser usado nos estudos contemporâneos. Com Giorgio Agamben o conceito é ampliado para se tornar a base da compreensão dos paradigmas do campo de concentração e dos refugiados como demonstração da vida nua absorvida pela política na tentativa de se reproduzir o modelo de Cristo em que a vida privada e pública coincidem sem resíduos,

\section{Biopolítica e dispositivo cristão em Michel Foucault}

É nesse segundo contexto que Foucault desenvolve seus estudos sobre biopolítica. Primeiro no curso de 1975-6, Em defesa da Sociedade (2010), em seguida especialmente com a publicação de Vontade de Saber (1988), e os cursos Segurança, Território, População (2008a) e Nascimento da Biopolítica (2008b). No ritmo das pesquisas foucaultianaso que é observado com a inserção da vida na política não é uma simples predisposição biológica a se adestrar, nem o que pode ser feito farmacologicamente para evitar as dissidências, a questão 
de Foucault é compreender em que medida a vida foi absorvida pela política gerando uma nova forma de governança.

\begin{abstract}
Uma das mais maciças transformações do direito político do século XIX consistiu, não digo exatamente em substituir, mas em complementar esse velho direito de soberania - fazer morrer ou deixar viver - com outro direito novo, que não vai apagar o primeiro, mas vai penetrá-lo, perpassa-lo, modifica-lo, e que vai ser um direito, ou melhor, um poder exatamente inverso: poder de "fazer" viver e de "deixar" morrer. O direito de soberania é, portanto, o de fazer morrer ou deixar viver. E depois, este novo direito é o que se instala: o direito de fazer viver e de deixar morrer (Foucault, 2010, p. 202).
\end{abstract}

A biopolítica substitui a governança soberana que zelava sobre a vida através da ameaça de morte, por uma forma de governo que domina a vida desde sua formação fetal até os últimos suspiros. Um domínio que inviabiliza o aborto e a eutanásia porque os corpos não pertencem às pessoas, mas ao Estado. Assumir o poder de "deixar morrer" acaba sendo mais forte do que a possibilidade de "fazer morrer", uma vez que assim não se domina apenas aos desviantes, mas a toda a sociedade. A morte de um delinquente pode servir de exemplo, mas a manutenção da vida de todos é mais que exemplar, ela disciplina os corpos e governa a alma.

Assim como o deixar morrer assume uma função diferenciada no mundo disciplinar moderno, o fazer viver se integra as evoluções das ciências para criar um novo conceito de saúde e de necessidade de manter e prolongar a vida.

\begin{abstract}
Nos dias atuais, o biopoder assume uma relevância surpreendente, visto que o capitalismo e a tecnociência - amplamente representados não mais apenas na medicina, mas também pelas demais profissões da área de saúde - são os protagonistas dessa nova forma de poder. O fazer viver assume proporções jamais imaginadas, graças ao advento de novas técnicas de prolongamento da vida ou mesmo apenas de um corpo vivo. Essa manutenção, além de reforçar o poder dessas áreas do saber, torna a duração da vida, muitas vezes por meios extraordinários, uma fonte interminável de rentabilidade econômica e experimentação médica (Candiotto; D’Espíndula, 2016, p. 39).
\end{abstract}

Não importa mais em que contextos de relação com o mundo, a vida deve ser mantida a todo preço. A morte honrada de um soldado em campo de batalha ou a vontade de morrer em casa do pai de família, são substituídos pela necessidade de manter o corpo vivo, mesmo que muito da humanidade deste corpo já se tenha perdido. Gestos famosos como o de Bob Marley, que optou por ver seu melanoma se desenvolver a amputar parte do corpo, e preferiu sair do hospital na Alemanha e ser tratado e enfrentar uma viagem cansativa, mas voltar para a Jamaica (ainda que nunca tenha concluído seu intento), são vistos como uma afronta ao dever estatal de manter o corpo vivo. Assim como Platão não entende a passividade de Sócrates 
diante de seus algozes, a biopolítica não entende como Marley, e tantos outros como ele, se deixam morrer por suas convicções. Ao não entender essa prática criam mecanismos que impedem e criminalizam a eutanásia e o suicídio.

Para compreender este poder biopolítico Foucault se utiliza do modelo do pastorado cristão (2008a) que tem como fim a salvação física e espiritual dos governados e se relaciona com a verdade sempre de forma mediada pela expertise do pastor e do assujeitamento do rebanho. Objetivando a salvação é necessário que o rebanho de fiéis siga as diretrizes de seu pastor se entregando de corpo e alma ao que lhes é determinado por este. Essa entrega é controlada por dispositivos como a confissão, que faz com que os fiéis não possam guardar segredos para si, ou a infalibilidade papal, que indica que os conselhos dados pelos pastores seriam algo sempre certeiro, jamais podem ser questionado pelos fiéis. Como o fiel não pode agir por si mesmo ele acaba sendo assujeitado, formado sujeito não por suas convicções, mas pelo que os dispositivos impregnam nele.

\section{A vida nua e biopolítica em Giorgio Agamben}

Para seguir essa análise tomaremos o conceito de dispositivo tal qual ele é desenvolvido por Giorgio Agamben a partir das indicações de Foucault.

\footnotetext{
Generalizando posteriormente a já bastante ampla classe dos dispositivos foucaultianos, chamarei literalmente de dispositivo qualquer coisa que tenha de algum modo a capacidade de capturar, orientar, determinar, interceptar, modelar, controlar e assegurar os gestos, as condutas, as opiniões e os discursos dos seres viventes. Não somente, portanto, as prisões, os manicômios, o Panóptico, as escolas, a confíssão, as fábricas, as disciplinas, as medidas jurídicas etc., cuja conexão com o poder é num certo sentido evidente, mas também a caneta, a escritura, a literatura, a filosofia, a agricultura, o cigarro, a navegação, os computadores, os telefones celulares e - por que não - a própria linguagem, que talvez é o mais antigo dos dispositivos, em que há milhares e milhares de anos um primata - provavelmente sem se dar conta das consequências que se seguiriam - teve a inconsciência de se deixar capturar (Agamben, 2009, p. 40-1).
}

Para além dos aparelhos foucaultianos, muito mais amplos em sua capacidade de assujeitar o coletivo, Agamben faz referências a elementos mais simples e imediatos no assujeitamento individual como a caneta ou o celular. O que para ele seria a base para a afirmação de uma destruição da experiência (2008a), uma vez que são estes dispositivos que passam a fazer experiência no lugar do sujeito. De celular em punho qualquer um pode gravar os momentos mais imperdíveis, e perder a possibilidade de experimentá-los ao vivo. 
Os trabalhos de Foucault com a noção de biopolítica são de meados dos anos 70 até seus últimos escritos no início da década de 80. Agamben absorve essa noção, mas não se limita a uma simples reprodução conceitual. O ponto de partida para Agamben é essa noção foucaultiana de que a vida foi aprisionada pela política e a forma desse aprisionamento segue o modelo do dispositivo cristão do pastorado. As primeiras pesquisas de Agamben estão impregnadas da influência de Martin Heidegger, de quem ele foi aluno nos seminários de Le Thor, e de Walter Benjamin, de quem foi editor das obras na Itália. Neste sentido Agamben analisa inicialmente as possibilidades e impossibilidades da experiência, sobretudo a artística, no mundo contemporâneo. Suas primeiras impressões são de que existe uma destruição da experiência autêntica, porque os homens deixaram de se relacionar diretamente com as coisas. Posteriormente, com a sua formulação do conceito de dispositivo se pode observar a proximidade deste aspecto com as discussões políticas que se iniciarão com o projeto Homo Sacer.

O grande projeto filosófico de Agamben foi o Homo Sacer, iniciado em 1995 com a publicação de $O$ poder soberano e a vida nua (2002). Nesta obra o filósofo indica que pretende seguir as indicações foucaultianas, mas sua leitura sempre será mediada pela presença do pensamento de Heidegger e Benjamin, assim como de Franz Kafka, Carl Schmitt, Hannah Arendt, além de uma gama de autores da filosofia medieval e o que mais a sua erudição permitir referenciar. O início da discussão passa pela análise de Aristóteles e da forma como ele distingue entre a vida biológica e natural da zoé, comum a todos os animais, e a vida qualificada da bios, pertencente apenas aos homens. Essa análise é fundamental para a sequência dos argumentos de Agamben e para a distinção traçada por ele frente a Foucault, uma vez que: “A simples vida natural é, porém, excluída, no mundo clássico, da pólis propriamente dita e resta firmemente confinada, como mera vida reprodutiva, ao âmbito do oîkos" (Agamben, 2002, p. 10). Ao retomara a separação entre uma vida qualificada para a pólis e uma de aspecto natural para a ôkkos, Agamben começa a delimitar o espaço de ação da biopolítica como uma política econômica, que ao mesmo tempo inclui e exclui a vida natural e o governo da casa em suas funções.

Essa exclusão/inclusiva se efetiva por meio do conceito de vida nua.

A fórmula singular "gerada em vista do viver, existente em vista do viver bem" pode ser lida não somente como implicação da geração (ginoméne) no ser (ô̂sa), mas também como exclusão inclusiva (uma exceptio) dazoé na pólis, quase como se a política fosse o lugar em que viver deve se transformar em viver bem, e aquilo que deve ser politizado fosse desde sempre a vida nua. A vida nua tem, na política 
ocidental, este singular privilegio de ser aquilo sobre cuja exclusão se funda a cidade dos homens (Agamben, 2002, p. 15).

Mais uma vez é ao ambiente do dispositivo cristão que os teóricos da biopolítica vão recorrer ao pensar o conceito de vida nua. A vida do homo sacer, aquele que não pode ser sacrificado, mas está sujeito à morte a todo o tempo é pensada como nua no mesmo sentido em que os primeiros pecadores se reconhecem nus após a traição do mandamento divino. "A nudez só aparece por assim dizer negativamente, como privação da veste de graça e como presságio da esplendorosa veste de glória que os beatos receberão no Paraíso" (Agamben, 2010, p. 74). A nudez é teologicamente pensada como esse momento entre a queda e a volta ao Paraíso, quando nenhuma veste é capaz de escondê-la. Assim como a religião não existia antes do pecado e não existirá no Paraíso, uma vez que estando diretamente com Deus não é necessário se religar a Ele, assim também as vestes que cabem ao homem verdadeiramente são a da graça e da glória, tudo o que acontece neste interim é mera cobertura de suas vergonhas. A religião, assim como as vestes, são elementos apenas deste momento des-graçado e des-glorificado em que o homem vive a sua vida nua.

Para ultrapassar a sua nudez o homem deve transcender a sua animalidade interna, por isso o dispositivo cristão deve zelar para que os pecados não aconteçam nem por atos externos na vida pública;tampouco por omissões, pertinentes apenas ao privado;nem por palavras, que dependem do dispositivo da linguagem e de uma qualificação da bios; tampouco por pensamentos, que são impulsivos e particulares como a naturalidade da zoé. O dispositivo cristão deve dominar o todo da vida, com este aprendizado a biopolítica pretende domesticar o animal estatal.

\footnotetext{
Na leitura hegeliana de Kojève, o homem não é, de fato uma espécie biologicamente definida nem uma substância dada de uma vez por todas: é, acima de tudo, um campo de tensões dialéticas sempre já talhado por cortes que nele separam toda vez - pelo menos virtualmente - a animalidade "antropófora" e a humanidade que nela encarna. $\mathrm{O}$ homem existe historicamente apenas sob esta tensão: ele pode ser humano apenas na medida em que transcende e transforma o animal antropóforo que o sustenta, somente porque, por meio da ação negadora, é capaz de dominá-lo e, eventualmente, de destruir sua própria animalidade (Agamben, 2013, p. 26).
}

Se no dispositivo cristão o homem deve vencer a sua nudez para ser merecedor da graça divina, para a biopolítica é necessário vencer a animalidade da zoé para ser reconhecido como humano. Ou seja, a humanidade não é algo inerente ao homem, ele precisa lutar para demonstrar que é humano. Como recentemente denuncia o bordão "Direitos humanos para humanos direitos", retomado na crise dos refugiados hondurenhos na divisa com os Estados 
Unidos da América. Se um ser humano não se mostra direito ele não é merecedor dos Direitos humanos, ou seja, ele não deve ser enquadrado na humanidade que é merecedora de tais direitos. O que assusta é que desta vez a frase vem sendo repetida por autoridades mexicanas que querem extraditar os hondurenhos, e não apenas pelos norte americanos que não querem recebe-los.

Embora jamais tenha havido época política com tamanha multiplicação de Cartas, Constituições, declarações de direitos, o que mobiliza a opinião pública é sempre o discurso direto, simples redutivo e, apesar disso tudo (como é típico da gestão biopolítica), sempre imbuídas de verdade (Bazzicalupo, 2017, p. 21).

A noção de humanidade se torna volátil e estes refugiados se tornam apenas vidas nuas de quem ninguém sentirá falta caso sejam mortos. E mesmo que todos os direitos e deveres sejam descritos e legislados consensualmente, as verdades reducionistas do whatsapp e do twitter possuem um apelo muito maior. Nestes tempos em que os governantes optam por se pronunciar nas redes sociais a biopolítica se torna mais premente e os Direitos mais esvaziados. Um perigoso discurso que enfrentamos nacional e internacionalmente.

Mais uma vez, focando a noção de biopolítica, é necessário reforçar que o animal de dentro do homem, essa vida zoé, que deve ser rechaçado pela vida política é o mesmo a quem se pretende "fazer" viver com a condenação do aborto e da eutanásia, uma vez que "No homem, esses dois animais coabitam, mas não coincidem: a vida orgânica do animal-dedentro começa no feto antes da vida propriamente animal e, no envelhecimento e na agonia, sobrevive à morte do animal de fora" (Agamben, 2013, p. 32). A vida que se dignifica a ser chamada de humana é uma construção que sucede ao nascimento e precede à morte. No estado fetal, assim como no vegetativo, não existe ainda a vida qualificada como humana. Essa vida nua, incapaz de ser pensada como a de um humano, deve ser garantida pelo Estado, da mesma forma que a vida que foge aos modelos impostos pelo Estado deve ser descaracterizada como uma vida humana, perdendo assim todos os seus direitos.

O não humano é analisado por Agamben na terceira parte de seu projeto, mas no segundo livro a ser publicado, O que resta de Auschwitz (2008b). Nele Agamben trata o campo de concentração como um paradigma para se compreender o contexto político atual e no que a biopolítica transforma o cidadão. Analisando os testemunhos de Primo Levi sobre os sobreviventes do campo, Agamben indica que:

A vida, que o sobrevivente opta por "abraçar sem reservas", "o pequeno suplemento de vida" pelo qual está disposto a pagar o preço mais elevado, revela-se, contudo, no 
final, como algo que não é senão a vida biológica como tal, a simples impenetrável "prioridade do elemento biológico". Em um perfeito círculo vicioso, no qual o ato de continuar não é mais que um retroceder, a "vida adicional" que a sobrevivência abre é simplesmente um a priori absoluto (Agamben, 2008b, p. 98).

Assim a vida desses sobreviventes é apenas uma sobrevida. Uma vida publicamente vivida a partir de seus impulsos internos. Vida que não pode ser chamada de qualificada e que é mais fácil de ser retirada por qualquer outro. Com esse elemento Agamben consegue frisar as implicações do ingresso da vida nua na política por meio do uso de dispositivos que cada vez mais se afastam de sua origem cristã. Se o campo é um paradigma, também o é a figura do refugiado. Aquele que mais claramente sofre com os dois movimentos de inclusão e exclusão na política. O primeiro movimento é o de formar o bando humano, agregando toda vida a um mesmo contexto. Mas dele descende um segundo movimento de abandonar os casos desviantes.

E quando, como demonstrou Foucault, o Estado moderno, a partir do século XVII, começa a incluir entre seus cômputos essenciais o cuidado com a vida da população e transforma, assim, a sua política em biopoder é, sobretudo, por meio de uma progressiva generalização e redefinição do conceito de vida vegetativa (que torna então patrimônio biológico da nação) que ele realizará sua nova vocação (Agamben, 2013 , p. 26).

O mesmo movimento que inclui a vida nua na política e torna a vida vegetativa patrimônio da nação, exclui aqueles que não se comportam adequadamente. Em meio ao bando é possível vivenciar o mais completo abandono.

\section{Considerações finais}

Na conclusão da segunda parte de seu projeto no livro Opus Dei, Homo Sacer II, 5 (2013), Agamben expõe a noção de uma vida cristã como uma liturgia, ou seja, um colocar-se a serviço assim como o Cristo se colocou a serviço. O grande objetivo dessa liturgia é criar uma vida em que o interno e o externo coincidam sem resíduos como na vida de Jesus eles coincidem. Mas o dispositivo cristão reconhece que essa coincidência a ser buscada pelos fiéis não é algo simples de ser conquistado.

No mesmo instante em que o define como leitourgos e evoca para ele uma "liturgia diversa e melhor", o autor da carta sabe que o grande sacerdote da nova aliança fechou irrevogavelmente às suas costas as portas do templo. Nesse sentido, a diaforótera leitourgia não é uma celebração, isto é, algo essencialmente repetível (esse é o significado etimológico de celeber). O paradoxo da liturgia cristã é que ela, 
tomando por modelo de seu sacerdócio a ação litúrgica de Cristo archiereuse fundando as próprias celebrações sobre a Epístola aos Hebreus, comprometer-se-á a repetir um ato irrepetível, a celebrar o não celebrável (Agamben, 2013, p. 20).

O dispositivo cristão sabe dos limites nos quais se encontra. A imitação de Cristo é desejada, mas é impossível de ser celebrada. O problema maior é quando esse dispositivo é absorvido pela política sem a devida compreensão de seus limites. Na biopolítica se assume a intenção de fazer coincidir o interno e o externo, se assume o poder sobre a vida dos cidadãos e se pode jugar como inferior todo aquele que não consegue o impossível.

Dessa forma fica muito mais fácil controlar a sociedade. Os Direitos cabem apenas aos que o soberano considerar direitos. Como é impossível ser direito de fato, ou seja, ser como Cristo e coincidir a vida interna com a externa, qualquer um é revelado em sua nudez, usada a bel prazer do contexto. Em um momento se pode louvar um grupo religioso ou político, e no seguinte o mesmo pode ser transformado em objeto de perseguição. Neste sentido não se afasta muito do modelo de Cristo em sua entrada triunfante com ramos em Jerusalém e sua condenação popular ante a soltura de Barnabás. Ante a vida nua a esquerda brasileira pode ser eleita e reeleita por 4 mandatos e em seguida ser condenada em discurso público de um novo presidente à expatriação. Mexicanos podem desejar o ingresso nos Estados Unidos e criticar os hondurenhos que chegam ao país. Norte-americanos podem se esquecer de sua história de formação na diversidade e liberdade, e criar um discurso pela construção de muros nas fronteiras.

Ainda é necessário explorar mais o conceito de biopolítica. No atual estágio de nossa pesquisa a intenção foi demonstrar como ela se envolve com o dispositivo cristão e acaba gerando um produto muito mais agressivo, mas efetivamente presente em nossa sociedade. Os próximos passos exigem uma análise da possibilidade de uma contraposição a esse modelo que não parece distante de acabar.

\section{Referências}

AGAMBEN, G. Homo Sacer: O poder soberano e a vida nua I. Belo Horizonte: EdUFMG, 2002.

AGAMBEN, G. O que resta de Auschwitz:o arquivo e a testemunha. São Paulo: Boitempo, 2008 b.

AGAMBEN, G. Opus Dei:arqueologia do ofício. São Paulo: Boitempo, 2013.

AGAMBEN, G. O que é o contemporâneo? E outros ensaios. Chapecó: Argos, 2009.

AGAMBEN, G. Nudez. Lisboa: Relógio D’Água, 2010.

AGAMBEN, G. O aberto: O homem e o animal. Rio de Janeiro, 2013. 
AGAMBEN, G. Infância e história: Destruição da experiência e origem da história. Belo Horizonte: EdUFMG, 2008a.

BAZZICALUPO, L. Biopolítica: Um mapa conceitual. São Leopoldo: EdUNISINOS, 2017.

CANDIOTTO, C.; D’ESPÍNDULA, T.S. Biopoder e racismo político: uma análise a partir de Michel Foucault. In: CAPONI, S.; VALENCIA, M.F.V.; VERDI, M.; ASSMANN, S.J. (Orgs) A medicalização da vida como estratégia biopolítica. São Paulo: LiberArs, 2016, p. 31-44.

FOUCAULT, M. Em defesa da sociedade: curso no Collège de France (1975-1976). São Paulo: WMF Martins Fontes, 2010.

FOUCAULT, M. História da sexualidade I: Vontade de Saber. Rio de Janeiro: Edições Graal, 1988.

FOUCAULT, M. Segurança, território, população: curso no Collège de France (1977-1978). São Paulo: Martins Fontes, 2008a.

FOUCAULT, M. Nascimento da biopolítica: curso no Collège de France (1978-1979). São Paulo: Martins Fontes, 2008b. 


\title{
Igreja e movimentos sociais: \\ o papel das CEBs como espaço de resistência no período militar
}

\author{
Church and social movements: \\ the role of CEBs as a space of resistance in the military period
}

Paulo César Cedran ${ }^{16}$

pccedran@gmail.com

\begin{abstract}
Resumo: Ao abrir suas portas aos movimentos sociais, a Igreja inaugurou uma nova forma de articulação Igreja/Sociedade que ao nosso ver, garantiu muito mais a autonomia destes movimentos do que o seu domínio pela Igreja. Nesse sentido, mesmo as CEBs, possuindo uma relação intrínseca como a hierarquia católica, esta conseguiu estabelecer um grau de autonomia muito grande, seja na coordenação das comunidades, nas celebrações, nas decisões políticas do grupo. Portanto, diante deste contexto pretendemos em nossa comunicação analisar a relação Igreja/Povo, via movimentos sociais, de forma a relativizar o poder hierocrático da Igreja nos determinantes desta questão. Mesmo se tratando de uma análise com viés histórico datado na década de 70/80, acreditamos que as reflexões sobre esse período podem contribuir para a compreensão do cristianismo como possibilidade de atuação no espaço público por meio da ressignificação dos aspectos políticos e sociais que sustentam as comunidades eclesiais de base até os dias atuais.
\end{abstract}

Palavras-chave: comunidades eclesiais de base, movimentos sociais, igreja e política no Brasil.

Abstract: In opening its doors to social movements, the Church inaugurated a new form of Church / Society articulation, which, in our view, guaranteed much more the autonomy of these movements than its dominion by the Church. In this sense, even the CEBs, having an intrinsic relationship like the Catholic hierarchy, this managed to establish a very great degree of autonomy, be it in the coordination of communities, in the celebrations, in the political decisions of the group. Therefore, in this context, we intend in our communication to analyze the relationship between Church and People, through social movements, in order to relativize the hierocratic power of the Church in the determinants of this issue. Even if we are dealing with a historical bias analysis dating from the $70 \mathrm{~s} / 80 \mathrm{~s}$, we believe that the reflections on this period can contribute to the understanding of Christianity as a possibility of acting in the public space by means of the re-signification of the political and social aspects that sustain the ecclesial communities to the present day.

Key-words: basic ecclesial communities, social movements, church and politics in Brazil.

Ao abrir suas portas aos movimentos sociais, a Igreja inaugurou uma nova forma de articulação Igreja/Sociedade que ao nosso ver, garantiu muito mais a autonomia destes movimentos do que o seu domínio pela Igreja. Nesse sentido, mesmo as CEBs, possuindo uma relação intrínseca com a hierarquia católica, esta conseguiu estabelecer um grau de autonomia, seja na coordenação das comunidades, nas celebrações, nas decisões políticas do

\footnotetext{
${ }^{16}$ Paulo César Cedran é Mestre em Sociologia, Doutor em Educação Escolar pela Unesp de Araraquara, Supervisor de Ensino da Diretoria de Ensino - Região de Taquaritinga, Docente do Centro Universitário Moura Lacerda de Jaboticabal e Uniesp - Taquaritinga. E-mail pccedran@gmail.com
} 
grupo. Portanto, diante deste contexto, pretendemos em nossa comunicação analisar a relação Igreja/Povo, via movimentos sociais, de forma a relativizar o poder hierocrático da Igreja nos determinantes desta questão. Mesmo se tratando de uma análise com viés histórico datado na década de 70/80, acreditamos que as reflexões sobre esse período podem contribuir para a compreensão do cristianismo como possibilidade de atuação no espaço público por meio da ressignificação dos aspectos políticos e sociais que sustentam as comunidades eclesiais de base até os dias atuais.

A Igreja a partir do contexto sócio-político das décadas de 50-60, viu-se obrigada a mudar sua conduta frente a uma série de problemas institucionais e sociais presentes nessas décadas. Ao mesmo tempo, começa a surgir na sociedade, e não somente dentro da Igreja, os chamados movimentos populares ou movimentos de base que pautar-se-ão pela forma diferenciada de se relacionar com a Igreja e de criarem estratégias de lutas e organização no período militar.

Para melhor compreendermos a questão das CEBs, convém estudarmos o que seriam esses movimentos populares e quais as implicações na relação sociedade/Igreja e, a partir daí compreendermos a gênese das CEBs, que basicamente surgem no bojo dos movimentos sociais de base, ou como muitos autores denominaram de novos movimentos sociais. ${ }^{17}$

Devemos considerar nesta análise da emergência dos movimentos sociais de base, as mudanças ocorridas na Igreja, seja Particular ou Universal. Com isto teremos pistas para compor o quadro das CEBs e determinar o seu papel político-eclesial nas décadas de 60 e 70 .

Para o estudo dos chamados movimentos populares recorremos à coletânea organizada por Paul Singer e Vinícius Caldeira Brant, ${ }^{18}$ cuja contribuição e importância, está

\footnotetext{
${ }^{17}$ Para a análise do que seja os chamados "Novos Movimentos Sociais", ver: EVERS, T. "De costas para o Estado, longe do Parlamento", in Novos Estudos Cebrap, n. 1, Abril de 1983, p.25-40, e "Identidade - a face oculta dos novos movimentos sociais", in Novos Estudos Cebrap, n. 4, Abril de 1984, p. 11-23; LACLAU, E. "Os Novos Movimentos Sociais e a Pluralidade do Social", in Revista Brasileira de Ciências Sociais, n. 2, volume 1, Outubro de 1986, p. 41-7. Editora Vértice/Revista dos Tribunais/ANPCS, São Paulo; TOURAINE, A. Os Novos Conflitos Sociais. Para Evitar Mal-Entendidos, in Lua Nova - Revista de Cultura e Política, p. 5-17, São Paulo, CEDEC/Editora L\&PM, Junho 89, nº 17; FRANK, A. G. \& FUENTES, M. Dez Teses Acerca dos Movimentos Sociais, in Lua Nova - Revista de Cultura e Política, p. 18-48, São Paulo, CEDEC/Editora L\&PM, Junho $89, \mathrm{n}^{\circ} 17$.

${ }^{18}$ A publicação do livro "São Paulo: o povo em movimento", representou um marco em relação aos estudos sobre Movimentos Sociais. Como lembra Eder Sader ao justificar a utilização desta obra para sua pesquisa: "Em 1980 foi publicado o livro São Paulo: o povo em movimento. Sua enorme importância não advêm apenas do fato de conter estudos pertinentes sobre o tema dos movimentos sociais. Sua primeira importância reside no fato de encará-los como modalidades da emergência das classes populares em São Paulo”. É dessa ótica que procurei pesquisar os movimentos sociais aqui. Uma primeira particularidade que os autores daquele livro apontam nos movimentos sociais dos anos 70 é o seu caráter fragmentado. Só que tal fragmentação não foi vista como sinal de insignificância, ou inviabilidade. Recusando os modelos apriorísticos para definir a realidade, eles se perguntaram sobre o significado dessa realidade, do modo como ela se apresentava" (SADER, 1988, p.197).
} 
no enfoque diferenciado que estes autores deram, acerca da forma como vinham sendo conduzidas até aquele momento, os estudos sobre os movimentos sociais.

A coletânea organizada por Singer e Brant, refere-se basicamente à grande São Paulo, mas não deixa de ilustrar de certa forma, a emergência das classes populares no cenário político do país na década de 70 .

O texto de Brant tece uma crítica aos estudos até então realizados sobre movimentos populares, no sentido de enfatizar que esses estudos destacam as classes populares no Brasil, a partir de sua ausência no cenário político dos grandes embates sociais, fazendo com que as informações já acumuladas por essas pesquisas, refiram-se mais às condições ou determinações prévias do que seriam esses movimentos, do que a eles próprios, enfim; da maneira com que estavam emergindo no cenário político e social do país.

Esta crítica de Brant, tornou-se singular no universo das análises desenvolvidas até o momento sobre o tema, justamente por levar à tona, a questão do mecanicismo e determinismo dessas análises. Esta forma de análise criticada por Brant, partia de um modelo teórico de inserção das camadas populares no cenário político e desta na relação com a conjuntura brasileira. A partir daí, passava a fazer correlações com um modelo teórico préestabelecido. A partir do momento que estas correlações não aconteciam de forma idêntica ao modelo, passava-se a considerar, portanto, que as camadas populares estavam então ausentes do cenário político do país. Consequentemente, as análises enveredaram-se pelo caminho das determinações prévias dessa ausência, e não ao próprio movimento que estaria existindo, mas não da forma ideal proposta pelo modelo teórico adotado. Partindo desta deficiência, Brant procurou estudar os movimentos em si, tentando perceber a visão que esses movimentos sociais tinham de si próprios e dos problemas que eles enfrentavam.

Ao afirmar que a emergência dos movimentos populares em São Paulo, na década de 70, dá-se de forma fragmentada, Brant busca nas condições de repressão extremada, contra a livre expressão dos interesses populares, a explicação para esta fragmentação. Esta, portanto, seria uma estratégia de luta e não um sinal de desarticulação das lutas sociais. Também esta fragmentação demonstra que se toma difícil a caracterização desses movimentos e

Livro "Quando Novos Personagens Entraram em Cena. Experiências, Falas e Lutas dos Trabalhadores da Grande São Paulo (1970-1980)". Editora Paz e Terra, Rio de Janeiro, 1988. Maria Helena Moreira Alves em seu Livro "Estado e Oposição no Brasil (1864-1984)", op.cit., nota no 22 também refere-se ao trabalho de Paul Singer e Vinícius Caldeira Brant (Org.) no livro "São Paulo: o povo em movimento" ao afirmar que "Excelente resumo dos diferentesmovimentos de base existentes no Brasil consta do trabalho coletivo editado por Paul Singer e Vinícius Caldeira Brant...”(ALVES, 1984, p.226). 
principalmente a centralização dos conflitos, e mesmo o intercâmbio permanente desses movimentos sociais, sob os diversos âmbitos de lutas e reivindicações.

A fragmentação dos movimentos sociais considerada como resposta à repressão, prefigurava a alternativa popular encontrada para manter a possibilidade de organização, mesmo que fosse via fragmentação, isolamento das ações como forma de organização possível no quadro político do momento.

Ora, esta fragmentação representou uma organização que se apresentou de forma defensiva pelos segmentos das classes populares. Para Brant, esta forma de ação tinha um duplo caráter diante da ação repressiva do Estado:

1. não despertar a suspeita do Estado que disseminava o terror através de castigos exemplares aos opositores do Regime;

2. utilizar-se de fragmentação desses movimentos como forma de responder às dificuldades impostas pelo Estado através da articulação entre elementos da base nos grupos intermediários para exercerem o caráter contestatório e reivindicatório dessas lutas populares.

Neste contexto, reafirmamos que o papel da Igreja aparece como salvaguarda dos movimentos, ao tornar-se o espaço privilegiado surgido como canal para a atuação desses movimentos. Dessa forma, esta contestação vai ao encontro do que Brant diz quanto à função desses movimentos, que era a de instituir novos canais de comunicação entre as classes populares, como forma alternativa no período ditatorial. Portanto, a busca de caminhos alternativos de organização frente aos canais oficiais de representação, afigurou-se, como única possibilidade para a continuidade das lutas. Quanto à Igreja, podemos dizer, tomou-se local privilegiado para a frutificação dessas lutas.

Quanto aos meios de ação utilizados por estes movimentos, Brant atribuiu à conscientização ou a busca do convencimento individual, a alternativa viável de ação em detrimento das formas impessoais de mobilização e organização que passa a ser incentivada pela Igreja, conforme também Romano (1979) constata.

Este trabalho pessoal, recoloca no cenário dos movimentos sociais o resgate da ação individual, assentada nos laços primários de organização e solidariedade, redimensionando o processo de conscientização que passa a ser exercido pela ação interpessoal, desbancando a figura do líder máximo a conduzir o movimento, retirando também a frieza ou impessoalidade que a noção de grupos, associações, poderiam acarretar. Surge uma nova forma de conscientização, que repondo o papel das relações primárias de fraternidade, base de origem 
do próprio cristianismo, instaurou uma nova forma de organização baseada na fraternidade, mais do que na política.

Brant constatou a possibilidade, que a incorporação dos grupos de base em movimentos mais amplos, que tenham sido construídos de baixo para cima, constituíram-se de estruturas antigas transformadas por sua ação e, que, portanto, seriam fundamentais na busca de alternativa de correlação de forças políticas e sociais na grande São Paulo.

Portanto, a repressão extremada criou os vínculos de solidariedade entre os movimentos de natureza diversa e os indivíduos com posições políticas e ideológicas diferentes, que passaram a conquistar a liberdade de manifestação por parte dos movimentos e instituições que exprimiam a autonomia da sociedade diante do Estado.

Para encerrarmos as considerações de Vinícius Caldeira Brant acerca deste assunto, podemos citar a paráfrase que ele faz dos movimentos sociais com as águas de uma represa e as águas de um rio:

O contexto da chamada reabertura política não constitui mero esgotamento do período ditatorial, seja porque o regime tivesse cumprido seus objetivos, seja porque tivesse renunciado ao arbítrio como meio de atingi-los. Ele revela certamente a disposição do governo de adaptar-se a uma realidade social que escapa ao poder de previsão dos estados maiores e dos gabinetes tecnocráticos. Mas, ao contrário do que se diz com freqüência, essa disposição não se antecipa a uma crise iminente. Ela surge com o atraso do reconhecimento generalizado de que a sociedade reorganizouse à margem das pautas previstas para enquadrá-la. Não se trata de abrir as comportas antes que explodam pela pressão das águas. As represas tornaram-se vazias, enquanto riachos e enxurradas correm fora dos leitos primitivos. De forma talvez inédita na história brasileira, a centralização extrema do poder tanto econômico como político resultou num descontrole de tal monta que não se explicaria, nem pela incompetência nem pela fragilidade de seus detentores. (Brant, 1983, p.24-5, grifo nosso)

Portanto, esses movimentos sociais passaram a recolocar na ordem do dia, a representação, a participação, como fundamento da democracia tanto almejada neste período de repressão militar, ao mesmo tempo que, superou todas as previsões do governo, inaugurando nas forças primitivas de sociabilidade, a alternativa encontrada para opor-se ao autoritarismo militar e político do momento.

Para finalizarmos nossa análise acerca das alternativas de ação pastoral da Igreja no período militar, convém analisarmos alguns aspectos quanto a gênese, estrutura e função das CEBs, não esquecendo que as influências ad intra na Igreja (Universal e Particular) e ad extra (na sua atuação na sociedade brasileira e latino-americana) são indispensáveis para traçarmos um percurso histórico das $\mathrm{CEBs}^{19}$ no Brasil.

\footnotetext{
${ }^{19}$ Para o percurso histórico do surgimento das CEBs no Brasil utilizamos o esquema cronológico proposto por Henrique Cristiano José de Matos no seu livro CEBs - Uma interpretação Para o Ser Cristão Hoje, op.cit., nota n ${ }^{\circ}$
} 
O surgimento propriamente dito das CEBs deu-se entre os anos de 1955 e 1960, aparecendo em algumas dioceses do Nordeste, sementes das futuras CEBs a partir de equipes de leigos encarregados de complementar as atividades paroquiais devido a escassez de vigários. Esta constatação reforça as colocações de Della Cava (1986) acerca dos problemas enfrentados pela Igreja, devido a ausência de padres para o trabalho eclesial, significando também uma forma de pressionar a instituição para a abertura a funções anteriormente restritas ao clero, criando a partir daí, ministérios leigos para a distribuição da Eucaristia, Equipes de Batismo, Equipes de Celebração da Palavra e Catequese.

O MEB (Movimento de Educação de Base) também contribuiu para o surgimento de inúmeros grupos de pequenas comunidades, que passaram a aliar o trabalho pedagógico ao religioso, dando ênfase à questão social. Conforme Vanilda Paiva já havia identificado, outras sementes contribuíram para o surgimento das CEBs:

- Movimentos do Natal (Rio Grande do Norte - anos de 1960);

- Catequistas Rurais - Barra do Piraí - Rio de Janeiro;

- Grupos de Evangelho - Goiás Velho;

- Encontro de Irmãos - Recife;

- Comunidades de Base - Nísia Floresta (Rio Grande do Norte), Crateús (Ceará), Vitória (Espírito Santo).

O Plano de emergência ${ }^{20}$ elaborado a partir de 1962, portanto no mesmo ano de início do Concílio Vaticano II, procurou expressar via CNBB, a colegialidade de ação episcopal e apresentar as CEBs como foco de evangelização. Já nos $3^{\circ}$ e $4^{\circ}$ Planos Bienais de Pastoral de Conjunto; "as CEBs são assumidas como prioridade: nas Diretrizes Gerais da ação pastoral de Igreja no Brasil (1983-1986), as CEBs receberam destaque especial dentro do objetivo geral de evangelização". (MATOS, 1985, p. 33.)

21 e 22, principalmente o capítulo I - intitulado "Contexto Sócio-Político E Eclesial”, p.13-34. Este mesmo capítulo foi sintetizado no Documento da Diocese de Jaboticabal intitulado "Evolução Histórica do Surgimento das CEBs", mímeo. Elaborado para o "Encontro Diocesano de CEBs", que ocorreu em 30.11.86. Esta síntese também é utilizada por nós na análise deste percurso histórico. Ver também CEDRAN, P. C. "CEBs: O que é?" Trabalho de conclusão apresentado ao Curso de Etnografia do Brasil, ministrado pela prof. Elda Rizzo de Oliveira, Faculdade de Ciências e Letras de Araraquara, mímeo, Araraquara, 1989. E também CEDRAN, P. C. "Comunidades Eclesiais de Base - CEBs", Trabalho apresentado para conclusão do Curso de "Bacharelado em Ciências Sociais" - F.C.L. - UNESP, Câmpus de Araraquara, sob a orientação da prof. Elda Rizzo de Oliveira, 1993, mímeo.

${ }^{20}$ Matos explica que "Em 1962, a CNBB publicou o "Plano de emergência", que visava a renovação de paróquia (Contendo princípios desta renovação, exigências fundamentais; objetivos centrais), preparando assim, o terreno para o I Plano de Pastoral de Conjunto de 1966-70, com suas seis linhas pastorais" (MATOS, 1985, p. 33). 
Matos evidencia o destaque que as CEBs recebem ao citar o $\mathrm{n}^{\circ} 134$ do documento "Diretrizes gerais da ação pastoral da Igreja no Brasil 1983-1986",(Documentos da CNBB, n 28)Edições Paulinas, São Paulo, 1983, que diz:

A ênfase dada às Comunidades Eclesiais de Base neste quadriênio manifesta claramente o interesse e o amor da Igreja no Brasil por esse 'novo modo de ser Igreja'. Elas se constituem fermento de espírito e vida comunitária, modelos concretos de comunhão e participação, de serviço, desprendimento e solidariedade. Aberta a todos, as CEBs florescem, principalmente nos meios populares, possibilitam a articulação dos pobres entre si e favorecem a vivência e a expressão de sua fé e de seu compromisso com a libertação integral do homem.(CNBB, 1983, p. 90.)

Vislumbramos no universo eclesial, a efervescência de uma série de atitudes que procuraram cada vez mais interligar as ações eclesiais com as ações sociais. Esta atitude fica clara quando consideramos o trabalho desenvolvido pelo MEB, prenunciando o surgimento das CEBs.

A terminologia CEBs - Comunidades Eclesiais de Base - aparece pela primeira vez no $1^{\circ}$ Plano de Pastoral de Conjunto da CNBB em 1966-70, sendo definidas como o espaço onde os cristãos não sejam anônimos e se sintam acolhidos e responsáveis.

Essa revitalização de laços pessoais de fraternidade pela Igreja, recuperou politicamente a metodologia de trabalho possível para desempenhar a conscientização num momento politicamente conturbado e de definições políticas e sociais no país.

Aliada a esta série de mudanças na Igreja Particular do Brasil, devemos considerar as mudanças ocorridas ad intra em nível da Igreja Universal.

Henrique Cristiano José de Matos identifica três momentos importantes neste universo de transformações:

1. Movimentos Pré-Conciliares;

2. Concílio Vaticano II;

3. Conferência de Medellín.

Os Movimentos Pré-Conciliares ganharam importância na medida que ocorreu uma movimentação dos leigos na Igreja, ocupando lugar de destaque, principalmente por sua atuação junto a A.C. (Ação Católica), com suas ramificações atendo a diversos setores: JEC (Juventude Estudantil Católica), JOC (Juventude Operária Católica) e JUC (Juventude Universitária Católica).

O Concílio Vaticano II iria referendar esta ação pastoral e a partir daí, ampliar a iniciativa da Igreja no processo de abertura - do sair-se de si mesma, e, por conseguinte, 
passar a intervir no mundo via ação comunitária, reconhecendo o leigo como sujeito do processo de evangelização.

A Conferência de Medellín representou a tentativa de aplicar as diretrizes conciliares à América Latina, que a partir do contexto desse continente, passou a fazer da opção preferencial pelos pobres, o caminho da esperança que deveria ser trilhado pelos povos latinoamericanos, como sintetiza Gustavo Gutiérrez:

O Vaticano II dá as grandes linhas de uma renovação da Igreja; Medellín assinala a pauta para uma transformação da Igreja em função de sua presença em um continente de miséria e de injustiça. (Gutiérrez, 1979, p. 114.)

Localizadas exclusivamente nas áreas socialmente pobres do campo e da cidade, os mais desfavorecidos encontraram com o surgimento das CEBs, a motivação religiosa através de grupos de cristãos, que em comum, ouvem e meditam a palavra de Deus; rezam, compartilham alegrias, esperanças e sofrimentos, procurando resolver comunitariamente os seus problemas locais, articulando vida e fé.

Neste sentido ao não limitar sua ação ao caráter exclusivamente piedoso,(Camargoet al., 1983.) as CEBs passam a constituir uma promissora trama de experimentação do exercício de novas formas de associação popular, procurando diminuir problemas vitais no campo e na cidade, os quais afligiam as classes populares.

A partir desta pedagogia desenvolvida pelas CEBs de articular a problemática cristã à problemática social, podemos considerar que as influências ad extra consideradas por Matos como determinantes fundamentais no surgimento das CEBs, relacionadas à crise do sistema capitalista aliada à crise do modelo de cristandade, demonstraram que havia uma correlação entre a tentativa de superação dessa crise, a partir da redefinição de um modelo de cristandade, que partiu de movimentos eclesiais, esboço de futuros movimentos populares, dos chamados novos movimentos sociais.

Passando a criticar a excessiva acumulação capitalista, a Igreja deixou de ocultar e legitimar esta exploração, substituindo seu discurso religioso inócuo por um discurso que discorra sobre a raiz das injustiças sociais do mundo, e principalmente da América Latina.

Aliada a este fato, Matos considera também que a retomada do poder pelas classes hegemônicas, incentivou a articulação da Igreja com as classes populares, principalmente no Brasil, a partir da artificialidade do Milagre Brasileiro e da repressão política. 
Essa busca da democratização das estruturas paroquiais e diocesanas, ${ }^{21}$ mostrou que as CEBs podiam ser vistas a partir de dois movimentos básicos:

1. de baixo para cima - através da demanda por participação dos leigos no interior da Igreja Católica no Brasil;

2. de cima para baixo - através de uma Igreja no recorrente esforço de rearticulação com suas próprias bases.

Esse momento chamado por Camargo et al., de pré-história das CEBs, termina em 1964. A partir daí, teremos uma Igreja disposta a acolher novas formas de mobilização dos leigos, importantes para sua renovação e anunciadoras de uma nova identidade católica, com base em novas alianças.(Camargoet al., 1983.)

Poderíamos concluir que a partir daquele momento, as CEBs tornaram-se o veículo primordial para a execução de uma nova proposta de Ação Pastoral, considerando o contexto político e social do momento.

A abertura da Igreja aos anseios da população veio representar o seu reencontro com as bases, e principalmente fortalecer a organização popular num momento de pleno autoritarismo. Esta é, portanto, a alternativa encontrada pela Igreja e sociedade, que se tornou relevante dentro do horizonte dos movimentos populares emergentes, e que foram sem dúvida alguma, muito importantes para as mudanças no cenário religioso e político dos anos 70 e 80 .

Com a finalidade de responder aos desafios de uma prática libertária no contexto sócio-político do período militar, as CEBs também se apresentaram como uma forma de adequar as estruturas da Igreja ao concílio Vaticano II. Dessa forma as CEBs se tornaram uma plataforma válida para as mudanças sociais como afirmou Pe. Nelito Nonato Dornelas:

\footnotetext{
Hoje, passada a euforia inicial e tomando a devida distância, podemos constatar que as CEBs estão na raiz de vários movimentos sociais e têm contribuído para a formação de muitas lideranças no campo social e político. Foram responsáveis também, pela formação de lideranças leigas no interior da Igreja, que assumiram o jeito de viver e celebrar a fé de uma maneira nova (Dornelas, 2006, p.2/7)
}

Mesmo tendo passadas quatro gerações (Dornelas, 2006) afirma que as CEBs construíram suas histórias e hoje são conclamadas a se pronunciar sobre a sua identidade. Talvez muitas pessoas tenham a impressão de que as CEBs sejam algo do passado ou desapareceram, mas elas estão presentes com grande vitalidade. Com sua dinâmica própria os intereclesiaisque são os encontros realizados a cada cinco anos têm significado a afirmação do

\footnotetext{
${ }^{21}$ A análise completa de Dermi Azevedo encontra-se na Folha de S. Paulo, de 4 maio 86, p.6, Caderno $1^{\circ}$, intitulada "CEBs indefinidas entre autonomia e institucionalização".
} 
compromisso cristãos com os desafios concretos da sociedade. Assim, Dornelas (2006) conclui:

\footnotetext{
“(...) as CEBs não são o futuro da Igreja. O fato é que, sem as CEBs, a Igreja não terá futuro. D. Pedro Casaldaliga, quando perguntado sobre o que restou da Teologia da Libertação, respondeu com ironia teológica: 'sobraram apenas duas palavras: Deus e os pobres." (Dornelas, 2006. p.6/6 - 6/7)
}

Portanto, os desafios da sociedade neo-liberal estão ainda mais presentes em nosso país e reforçam que uma igreja sem os pobres conseqüentemente é uma igreja que necessita se reencontrar na experiência de Deus quando de fato recolocar os pobres como sua prioridade, num mundo cada vez mais desigual e injusto.

\section{Referências}

ALVES, M. H. M. Estado e oposição no Brasil (1964-1984). 2.ed. Trad. de Clóvis Marques. Petrópolis: Editora Vozes, 1984.

AZEVEDO, D. CEBs indefinidas entre autonomia e institucionalização. Folha de S.Paulo, São Paulo, 4 maio 1986, p.6.

BRANT, V. C. Da resistência aos movimentos sociais: a emergência das classes populares em São Paulo, ln: SINGER, P., BRANT, V. C. São Paulo: o povo em movimento. 4.ed. São Paulo: Ed. Vozes/Cebrap, 1983, p.9-27.

CAMARGO, C. P. F. de et al. Comunidades eclesiais de base: In: SINGER, P., BRANT, V. C. (Org.). São Paulo: o povo em movimento. 4.ed. São Paulo: Editora Vozes/Cebrap, 1983.

CEDRAN, P. C. CEBs. O que é? Trabalho de Conclusão apresentada à disciplina Etnografia do Brasil, Faculdade de Ciências e Letras-UNESP, Araraquara, 1989. Mímeo.

CEDRAN, P. C. Comunidades Eclesiais de Base - CEBs. Trabalho apresentado para a conclusão do Curso de Bacharelado em Ciências Sociais, Faculdade de Ciências e LetrasUNESP, Araraquara, 1993. Mímeo.

CNBB. Diretrizes gerais da ação pastoral da Igreja no Brasil 1983-1986. Edições Paulinas, São Paulo, 1983. (Documentos da CNBB, n.28).

DELLA CAVA, R. A Igreja e a abertura, 1974-1985. In: KRISCHKE, P., MAINWARING, S. (Org.). A Igreja nas bases em tempo de transição (1974-1985). Porto Alegre: L\&PM/Cedec, 1986, p.13-45.

DIOCESE DE JABOTICABAL. Evolução histórica do surgimento das CEB's. Documento elaborado para o Encontro Diocesano de CEBs - 30.11.86. Mímeo.

DORNELAS, N. N. A identidade das CEBs. Vida Pastoral. Maio/Junho 2006.p.1/7. Disponível: http://www.vidapastoral.com.br/artigos/eclesiologia/a-identidade-das-cebs/

EVERS, T. De costas para o Estado, longe do Parlamento. Novos Estudos Cebrap (São Paulo), n.1, p.25-40, abr. 1983.

FRANK, A. G., FUENTES, M. Dez teses acerca dos movimentos sociais. Lua Nova. Revista de Cultura e Política (São Paulo), n.17, p.18-48, jun. 1989.

GUTIÉRREZ, G. Teologia da libertação. Trad. de Jorge Soares. Perspectivas. Petrópolis: Editora Vozes, 1975.

LACLAU, E. Os novos movimentos sociais e a pluralidade do social. Revista Brasileira de Ciências Sociais (São Paulo), n.2, v.1, p.41-7, out. 1986. 
MATOS, H. C. J. CEBs - uma interpelação para o ser cristão hoje. São Paulo: Edições Paulinas, 1985.

ROMANO, R. Brasil: Igreja contra Estado (crítica ao populismo católico). São Paulo: Kairós Livraria e Editora, 1979. (Prismas, v.1).

SADER, E. Quando novos personagens entraram em cena - experiências, falas e lutas dos trabalhadores da grande São Paulo (1970-80). Rio de Janeiro: Editora Paz e Terra, 1988.

TOURAINE, A. Os novos conflitos sociais. Para evitar mal-entendidos. Lua Nova. Revista de Cultura e Política (São Paulo), p.5-7, jun. 1989. 


\title{
O "ser PT" e o "ser cristão": a moralidade religiosa por trás do Partido dos Trabalhadores rural da Zona da Mata e Leste Mineiro
}

\author{
The "being PT" and "being Christian": the religious morality behind the Partido dos \\ Trabalhadores of the Zona da Mata and Eastof Minas Gerais
}

\author{
Lívia Rabelo ${ }^{22}$ \\ lih.rabelo@gmail.com \\ Ramon Teixeira ${ }^{23}$ \\ ramoneps2014@gmail.com
}

\begin{abstract}
Resumo: A partir de uma abordagem histórico-processual, utilizando documentos históricos e relatos orais, buscamos compreender como elementos constitutivos de uma moralidade religiosa específica se relacionam à identidade política do Partido dos Trabalhadores (PT) rural. Trata-se da moralidade religiosa construída ao longo de experiências e cursos do Movimento da Boa Nova (Mobon) e das Comunidades Eclesiais de Base (Ceb's) que tem ênfase na união, solidariedade, humildade, justiça social,responsabilidade do cristão, conversão e testemunho. Sugerimos que haja uma representação sobre o "ser PT" entre as lideranças religiosas rurais fundadoras dos diretórios municipais que é intimamente relacionada à moralidade religiosa do Mobon.
\end{abstract}

Palavras-chave: Moralidade religiosa. Mobon. Partido dos Trabalhadores.

Abstract: We seek to understand how constitutive elements of a specific religious morality relate to the political identity of the rural Partido dos Trabalhadores (PT, acronym in Portuguese for "workers' party"). For this I use historical documents and oral reports, through a historical-procedural approach. It is about religious morality built on experiences and courses of the Movimento da Boa Nova (Mobon, acronym in Portuguese) and the Base Ecclesial Communities that emphasize unity, solidarity, humility, social justice, Christian responsibility and witness. We suggest the "PT being" refers to an identity among the rural religious leaders founders of the municipal directorates who is closely related to the religious morality of Mobon.

Keywords: Religious orality. Mobon. Partido dos Trabalhadores.

\section{Introdução}

Ética, moralidade e política são frequentemente tratadas de forma normativa, não se levando em conta o significado atribuído aos sujeitos para suas escolhas, tomadas de decisões

\footnotetext{
${ }^{22}$ Mestre em Economia pela Universidade Federal do Ceará (UFC), mestranda em Antropologia Social pelo Mestrado Interinstitucional entre a Universidade Federal do Rio de Janeiro e a Universidade Federal de Viçosa (MINTER MN/UJRJ/DCS/UFV), bacharel em Ciências Econômicas e licenciada em Ciências Sociais pela Universidade Federal de Viçosa (UFV). Orientada por John Comerford (PPGAS/MN/UFRJ) e coorientação por Fabrício Roberto Costa Oliveira (DCS/UFV).E-mail: lih.rabelo@gmail.com

${ }^{23}$ Licenciado em Letras pela Fafile/UEMG, bacharel em Ciências Sociais pela Universidade Federal de Viçosa (UFV) e mestranda em Antropologia Social pelo Mestrado Interinstitucional entre a Universidade Federal do Rio de Janeiro e a Universidade Federal de Viçosa (MINTER MN/UJRJ/DCS/UFV).
} 
e formas de agir no mundo. É em contraposição à esta abordagem que, inspirada nos estudos sobre a antropologia/etnografia das moralidades (Howell, 2005; Heintz, 2009; Fassin, 2012), temos como preocupação primordial identificar e compreender como premissas e discursos morais podem fornecer um potencial para novas abordagens na interpretação de instituições e práticas sociais de forma mais geral, ou seja, refletir sobre moral e política de forma nãonormativa.

Nesse sentido a centralidade desta pesquisa está posta na identificação e compreensão de como elementos constitutivos de uma moralidade religiosa do Movimento da Boa Nova $\left(\right.$ Mobon $\left.^{24}\right)$, se relacionam com a identidade partidária de lideranças religiosas e políticas que passaram por tal movimento e fundaram diretórios do Partido dos Trabalhadores (PT) em seus pequenos municípios.

Partimos de uma abordagem histórico-processual, recortado para fins analíticos, com iníciono Movimento da Boa Nova (Mobon) ${ }^{25}$. Trata-se de ummovimento pós conciliar da Igreja Católica de caráter evangelizador, que tem como objetivo a formação de lideranças leigas católicas e da vida em comunidades, tendo seu ápice de atuação entre as décadas de 1960 e 1990. O movimento ganhou força especialmente entre os trabalhadores rurais com baixa escolaridade formal, sendo visto por estes como um agente de aprendizagem. Assim, os que denomino aqui como liderança religiosa são trabalhadores e trabalhadoras rurais de baixa escolaridade formal, que participaram dos cursos do Mobon, se destacando e se tornando uma liderança religiosa, com a missão de "passar para frente" 26 os ensinamentos bíblico-religiosos que haviam recebido.

O Movimento da Boa Nova se utiliza de uma metodologia característica para formação de lideranças religiosas que, entretanto, pode ser visto como uma formação de lideranças de outras dimensões. Assim esta metodologia pode ser pensada não apenas na dimensão religiosa, mas também na dimensão política, sendo esta última tendo desdobramentos tanto na micropolítica como na macropolítica.

A coerência necessária entre "oração e obras" configura o "testemunho de vida", ou seja, no nível da micropolítica, do agir no mundo cotidiano. Já com relação à macropolítica, há uma participação significativa de muitas das lideranças formadas pelo movimento na

\footnotetext{
${ }^{24}$ A partir daqui chamarei apenas de moralidade religiosa a moralidade religiosa específica deste grupo de interconhecimento em análise, ou seja, camponeses católicos que participaram do Movimento da Boa Nova (Mobon) criando ou animando as Comunidades Eclesiais de Base (Ceb's).

${ }^{25} \mathrm{O}$ Mobon também faz parte de um processo surgindo como um desdobramento do Movimento de Apostolado dos Pioneiros do Evangelho (MAPE), que manteve seu habitus católico militante (Oliveira, 2012), embora o foco tenha se deslocado da polêmica e discussão inicial para formação de comunidades. Para saber mais sobre o Mobon ver Araújo (1999), Comerford (2003), Oliveira (2012), Rabelo (2017), entre outros.

${ }^{26}$ As expressões entre aspas são termos e expressões utilizadas pelas lideranças estudadas.
} 
fundaçãodos Sindicatos dos Trabalhadores Rurais (STR's) ${ }^{27}$ e dos diretórios municipais do Partido dos Trabalhadores (PT)na Zona da Mata Mineira.

De acordo com Oliveira (2009), em fins da década de 1970, os ideais da Teologia da Libertação estiveram mais presentes nos cursos do Mobon, sendo o foco na necessidade de atuação social e política dos leigos para buscarem justiça social, possibilitando uma vida terrena mais justa. Já na década de 1980, após o processo de redemocratização, setores da Igreja Católica, como o Mobon, tiveram forte significação eleitoral.

Neste trabalho, partimos das considerações já anunciadas por Cintrão (1996) de que lideranças religiosas que se conheceram e estabeleceram uma rede de interconhecimentos (Weber, 2009) iniciaram um processo de sociabilidade e solidariedade que se aprofundou ainda mais com a formação dos Sindicatos dos Trabalhadores Rurais (STR's). Os sindicatos organizados na Zona da Mara Mineira construíram uma ArticulaçãoSindical de quinze sindicatos organizados em três microrregionais, que posteriormente foi formalizada como Polo Regional da Federação dos Trabalhadores na Agricultura de Minas Gerais (FETAEMG) (Comerford, 2003)

O material de análise para essa pesquisa foi construído baseado em relatos de onze lideranças ${ }^{28}$, de 5 sindicatos, totalizando representantes das três microrregionais, o STR'S 1 da microrregional 1, o STR's 2 da microrregional 2 e os STR's 3, STR's 4 e STR's 5 da microrregional 3. Tais relatos indicavam caminhos a percorrer nos documentos históricos e notas dos cursos do Mobon presentes nos Cadernos de Cora Furtado de Melo, parto de elementos recorrentes nas narrativas e analiso os documentos relativos aos cursos do Mobon. No que tange à análise documental, focamos em livros históricos sobre o Movimento da Boa Nova, em documentos analisados na Sede do Mobon, como os cadernos que registram as listras de presença, livros redigidos a mão sobre a história do Movimento e fotos, eno material de Cora Furtado Melo $^{29}$ que contêm anotações manuscritas, livretos e folhetos referente às atividades do Mobon as quais participava, desde a década de 1970.

\footnotetext{
${ }^{27}$ Entre meados da década de 1980 e meados da década de 1990 foram fundados na Zona da Mata15 STR's assessorados pela CUT e pela CPT (cf. TEIXEIRA, 2017, p.13-15).

${ }_{28}$ Os nomes utilizados, salvo nome públicos, são fictícios a fim de proteger a identidade das lideranças.

${ }^{29}$ Cora Furtado de Melo foi uma liderança religiosa, historiadora e pedagoga, e considerava importante registrar o conteúdo dos cursos que participava. Participou de quase todos os cursos do Mobon e deixou registros em cadernos e pastas, que contém anotações dos escritos no quadro, os livrinhos de evangelização utilizados (colados) e as repostas passadas por seu grupo (normalmente, se faziam pequenos grupos para elaboração de respostas aos missionários).
} 


\section{2. "Ser cristão" e a moralidade religiosa do Mobon/Ceb's}

Assumindo que os discursos religiosos que traziam a "Boa Nova do Evangelho" são tratados como verdades e funcionam como normas, não no sentido de legislação, mas numa segmentação dual entre o que é normal e o que é anormal (Foucault, 2010). O "ser cristão", no contexto dessa rede de interconhecimento (Weber, 2009) religiosa, tem ênfase nos princípios de que "Jesus ama a todos, mas tem preferência pelos pobres" (Medellin, 1968) e que "assim também a fé: se não tiver obras, é morta em si mesma." (Tg2.17) e, portanto,depende de determinadas condutas no agir do sujeito.Assim, o comportamento normal, ou seja, normativamente incentivado, dentro de uma comunidade religiosa cristã é agir de acordo com a os ensinamentos bíblico-religiosos, sendo que os que não seguem são vistos como anormais, ou seja, não dão o "testemunho de vida". Ora, mas se "a fé sem obras é morta", dar o "testemunho de vida" se faz elemento fundamental no modelo de "ser cristão" verdadeiro. Dito de outro modo, os que "só rezam com a boca" são vistos como cristãos menos legítimos por tais lideranças. Nesse sentido, "ser cristão" e dar o "testemunho de vida" estão intimamente conectados.

É importante reiterar que as normas não são necessariamente regras, mas sim, condutas e comportamentos já naturalizados como normas internalizadas que constroem e reconstroem o sujeito ao longo de sua trajetória de vida. De acordo com Howell (2005: 4) "a relação entre valores morais e prática é dinâmica. Os valores estão continuamente mudando e se adaptando através de escolhas e práticas reais, enquanto, ao mesmo tempo, continuam a informar e moldar escolhas e práticas" (Howell, 2005: 4, tradução livre).

Passamos agora aos elementos dos discursos religiosos que constituem a moralidade religiosa do Mobon/Ceb's. Para fins analíticos, separo os elementos em dois níveis, qual sejam, a dimensão de princípios e normas e a dimensão da prática orientada pelas normas incorporadas, ou seja, o agir no mundo.

\subsection{Os elementos constituintes da moralidade religiosa no Mobon}

Acreditamos haver a elaboração de um discurso ético-moral relativo às experiências no Mobon/Ceb's, por conseguinte, me parece interessante analisar alguns dos elementos que constituem tal discurso que estaria fundado no que chamo aqui de moralidade religiosa. Fazse necessário ressaltar que se trata de uma moral de um grupo específico da Igreja Católica que se identifica com a Teologia da Libertação e a "preferência pelos pobres". Elementos 
recorrentes, como: união e solidariedade; justiça social, responsabilidade do cristão e missão; humildade e resiliência; e "fé e vida", "oração e ação" se fizeram presentes nas narrativas. A seguir me dedico a afunilar minha atenção à maneira como esses elementos estavam e ainda estão presentes nos eventos do Mobon.

Dentre os elementos compreendidos como princípios e normas estão a união, a solidariedade e a humildade. O princípio da união como central entre os fiéis que passaram pelos cursos do Mobon fica evidentes em diversas documentos e cursos. Em especial, o Curso da Boa Nova, teve como foco a importância da vida em comunidade. Como indica no material manuscrito de Cora Furtado de Melo, que participou do curso da Boa $\mathrm{Nova}^{30} \mathrm{em}$ setembro de 1970, em Iapu-MG. O item seis, "Vivência Comunitária" versa sobre a importância da união entre os fiéis.A vida comunitária emerge como crucial para o verdadeiro cristão, já que a conversão é vista como inserção e engajamento na vida religiosa da comunidade. Assim, as assertivas "o homem não vive isolado", "o cristianismo exige vida comunitária" trazem consigo as premissas de quão significativa são as relações interpessoais. Deve haver engajamento na comunidade de forma a apoiar os convertidos, construindo uma força que vem da união, da amizade, do diálogo. "Na comunidade deve haver participação, ambiente de família, confiança, liberdade, aceitação, muita solidariedade" (Boa Nova, 1970). É nesse ambiente que a fé se constrói e se fortifica. Em suma, em uma comunidade deve haver um ambiente familiar, onde as pessoas se sintam à vontade, pertencente e tenham confiança suficiente para participar de forma solidária. A comunidade é um espaço de união e solidariedade.

Em setembro de 1972, foi oferecido no mesmo município o Curso de Aprofundamento e Revisão, em que,entre outros pontos,refletia sobre os problemas de comunicação, enfatizando a importância da união e colaboração nos trabalhos feitos em grupo para que a comunicação fosse efetiva. "O trabalho em grupo não é competição. É colaboração. Se os componentes do grupo não forem capazes disto, é sinal de que não estão maduros para o trabalho em equipe e muito menos para a comunicação" (Curso de Aprofundamento e Revisão, 1972,p.5).

Também no livreto, editado na década de 1980, A Caminhada de Jesus (1985), está clara a ênfase na união ao tratar dos objetivos da Boa Nova trazida por Jesus.

\footnotetext{
${ }^{30} \mathrm{O}$ conteúdo deste curso está presente no material de Cora Furtado de Melo. De agora em diante, sempre que citar livretos ou manuscrito de cursos colocarei apenas o título, o ano e a página referente.
} 
O primeiro objetivo da Boa Nova de Jesus é reunir as pessoas. É formar comunidade (Mc 1, 16-20). Formar comunidade é se comprometer com a causa do povo. É lutar contra o que divide e oprime. É desempelotar. É entrar na caminhada de Jesus. (A Caminhada de Jesus, 1985, p. 7, grifo da liderança).

A união e solidariedade vem também através do argumento da fraternidade com o lema da Campanha da Fraternidade 2018: "Vós sois todos irmãos" (Mateus 23, 8), numa espécie de parentesco relacional (Carsten, 2000) baseado em relações profundas e duradoras dada a partilha de uma história de luta e de memórias tanto de conquistas como de sofrimentos e enfrentamentos em busca de um ideal comum e religioso.

Vimos nessa seção como a união, a solidariedade, a vida em comunidade foi uma tônica presente nas atividades do Mobon e também nas Ceb's, já que os cursos e cantos eram replicados e ensinados nas comunidades. Percebemos também uma tendência a ver vantagens em comunidades pequenas, o que ajuda a compreender a dificuldade posterior que tais lideranças teriam com a ampliação dos grupos políticos aos quais pertenciam, ao aceitarem indivíduos orientados por outras condutas que não a religiosa.

No que tange ao princípio da humildade, é trazido como uma virtude cristã e acima de tudo para uma verdadeira liderança, era enfatizado que numa relação se troca experiências, se aprende com o outro e não só se ensina. O ensino nesse Movimento se assemelha a metodologias de Paulo Freire, com um ensino dialógico e não bancário. Segundo Freire (1996), uma das tarefas mais importantes da prática educativa é propiciar condições para que o educando possa se assumir enquanto ser social e histórico, como ser pensante, comunicante, transformador e criador em suas relações uns com os outros e com seus educadores. Ensinar não é transferir conhecimentos e conteúdo, mas sim um processo dialógico baseado na reciprocidade, por isso a importância de conhecer o universo simbólico de quem se ensina, como faz João Resende em suas “comparações". Reformar-se e aprender com o outro está intimamente relacionado com a humildade da liderança, com a instrução de ouvir mais do que falar, "aprender a ouvir o clamor do povo" (A Força do Restolho, 1987, p. 10) e não se sentir o dono da verdade. Ao escrever sobre um dos cursos em que esteve presente, Kerandel e Del canto $(1977$, p. 25), afirma que "o que se percebia era a humildade, a paciência e o esforço que faziam para tomarem consciência que cada um dele tem sua função".

Quando questionado sobre quais as práticas pedagógicas ou educativas o curso se fundamenta, Alípio afirma que: 
com a capacidade extraordinária que ele tem, né... e ai ele foi ajudando mais com as comparações, etcetera. Mas mais é a natureza do João Resende, ele é assim. Ele é comparativo. Então nós fomos mais aí. (Alípio Jacinto, relato concedido a Ramon Teixeira em 08.02.2018).

Esse aprendizado a partir da experiência dos missionários, foi transmitida nos cursos, principalmente os específicos para a formação de lideranças, como é o caso do Curso da Boa Nova. De acordo com a análise do material manuscrito de Cora Furtado de Melo, que participou do curso da Boa Nova em setembro de 1970, em Iapu-MG, o item cinco, "O Apostolado de Jesus Cristo" versa sobre elementos necessários à realização do apostolado, como

[...] O método de Cristo - [...] Não força. É oportuno. Sabe ouvir. Fala no momento oportuno. [...] Cristo valoriza os ouvintes. Falava para multidões, grupo, pessoas. Valorizava os encontros, as conversas. Queria uma resposta livre. [...] Zaquel: Cristo quase não fala. É amigo. Respeita-o. Escuta-o. Valoriza-o. [...] Adultera: respeita-a. É silencioso. Mostra-lhe o seu erro. Recomenda-lhe vida nova. [...] Pecadora: Cristo dá uma lição, uma mensagem aos ouvintes. Mostra o seu amor ao pecador arrependido. [...] Samaritana: Cristo demonstra paciência e simplicidade. Valoriza-a, levando-a à aceitação de Sua Mensagem. Anunciar o Cristo. Levar o ouvinte a encontrar-se com Cristo. (Cora Furtado de Melo, 1970: 15)

Estas anotações de Cora Furtado de Melo nos ajudam a compreender como esse aprendizado do "ouvir mais" foi incorporado aos cursos e se tornado uma estratégia pedagógica importante e transmitida de geração em geração. Também no material do Curso de Aprofundamento e Revisão de 1972, o item 3 que trata sobre os Cursos de Base, há uma passagem que ilustra bem o caráter da humildade necessária para ser uma liderança no que tange ao saber ouvir "Não vamos, então, aproximar-nos do outro como o 'dono da verdade'. Mas, como aquele que ajuda a descobrir a verdade" (Curso de Aprofundamento e Revisão, 1972, p.6).

Voltaremos nossa atenção agora para a segunda dimensão analisada, qual seja, a da ação no mundo, as consequências ou deveres do sujeito orientado por princípios cristãos. Vejamos, então, como tais elementos aparecem nos registros históricos. No que se refere ao princípio da justiça social que, pela responsabilidade do "cristão de Ceb's", é visto como o objetivo a ser alcançado pela missão do sujeito religioso. A postura do Movimento da Boa Nova quanto à Teologia da Libertação e, consequentemente, à "preferência pelos pobres" "só se revelou mais consistente na década de 1980; isso se deu mais em função da pressão e aproximação dos agentes mais engajados com as concepções liberacionistas do que por estudos e escolhas dos agentes sociais" (Oliveira, 2012,p. 25). Assim sendo, a temática da justiça social e da igualdade é frequente nas atividades do Movimento, como pode ser visto 
nos livretos orientadores dos encontros. Reestabelecer a justiça social "quebrada" exige a responsabilidade do fiel com tal causa. Em nota manuscrita na lombada do livreto $A$ Caminhada de Jesus (1985), que disserta sobre os objetivos da Boa Nova de Jesus, Cora Furtado de Melo toma nota do que sugiro ser uma sentença proferida pelo ministrante do curso em questão. Escreve ela "O objetivo de Jesus é acabar com a opressão e a divisão" e em seguida escreve "Obs. A presença do Pobre é sinal que a justiça de Deus foi quebrada. O projeto de Deus foi desviado" (Cora Furtado de Melo, 1985,p.7-8).

Ora, a busca de justiça social passa então a ser vista como uma missão. Entretanto, é importante compreender o que tais lideranças entendem por justiça social. Para além das pistas dadas nos relatos, busco fundamentá-las nos ensinamentos religiosos experienciados. Ainda no livreto A Caminhada de Jesus (1985), no item "De que lado fica Jesus", está posta a centralidade da Boa Nova nos fracos e pobres, apesar de não excluir ninguém.

Jesus anuncia a Boa Nova a todos. Não exclui ninguém. Mas Jesus faz o anuncio a partir dos pobres e dos enjeitados. O lugar, o ambiente de onde se faz o anuncio, é muito importante. A posição diante da vida fala mais do que as palavras. Por isso mesmo, Jesus, mesmo sem excluir ninguém, convive com aqueles que não tinham lugar dentro da sociedade da época. [...] Jesus dá atenção a quem não tem poder nem saber. É o caso dos fracos e os pobres. Quem não tinha lugar recebe um lugar na convivência com Jesus. Fica assim claro de que lado ficou Jesus. Ficou do lado dos que foram postos para escanteio. [...] Jesus se colocando do lado dos pobres nos ajuda a entender que os pobres nos levam a descobrir o Evangelho como Boa Notícia e Jesus como libertador. A posição de Jesus nos ajuda a entender que o pobre não é simplesmente o carente. É alguém capaz de lutar pela sua vida, pela sua libertação (A Caminhada de Jesus, 1985, p. 9-11, grifo da liderança).

Assim, ter responsabilidade social aparece como missão a ser realizada pelo cristão ao tratar dos objetivos da Boa Nova trazida por Jesus.

\footnotetext{
Um outro objetivo da Boa Nova é manter a consciência de que temos uma missão a realizar. Não podemos parar nas pequenas vitórias obtidas. Elas são forças para outras lutas. [...] Este objetivo da Boa Nova nos lembra que nossas comunidades devem ser missionárias. Não podem focar só no terreiro de sua cozinha, fechada dentro de seus limites. (A Caminha da de Jesus, 1985, p.8).
}

Alípio Jacinto fala sobre a política no cotidiano, sobre a visão de que política está relacionada ao sujo e que, na verdade, política é a luta pelo bem comum, é a própria responsabilidade do cristão.

o pessoal acha que política é um negócio sujo. Não, a política é um negócio muito bonito que é lutar pelo bem comum. Esse... ai falei do bem comum, de buscar o bem 
de todos, né só a gente ser egoísta não, né... tava falando de política. Então fé e política não é do Mobon não é... é do cristianismo. É de nós todos, a qualquer hora. E o Mobon está atento a isso aí. De vez em quando a gente faz a palestra sobre fé e política, o pessoal chama pra gente falar sobre as... eu falo das responsabilidades do cristão diante da política (Alípio Jacinto, relato concedido a Ramon Teixeira em 08.02.2018).

É nesse sentido que o Mobon atuou no âmbito micropolítico, combatendo a ideia estabelecida de que política era algo sujo (Palmeira e Heredia, 2010; Oliveira, 2012). Como pôde ser visto ao longo dos elementos trazidos até então, é forte a presença da conversão e do posterior testemunho de vida. Por isso a importância da conexão entre os princípios morais de união, solidariedade, humildade e justiça social e a ação do mundo do sujeito. Elementos com relação à prática cotidiana são a "responsabilidade social", a "conversão" e o "testemunho de vida" A coerência entre a oração e a ação na vida cotidiana, era não só esperada, mas exigida para se manter como liderança, já que será o exemplo vivo do modelo de vida a ser seguida. A vida da liderança leiga deve honrar a moralidade religiosa.

O livreto A Caminhada de Jesus (1985) vem trazer um modelo de caminhada exemplar a ser seguido pelos fiéis, já que descrever é prescrever (Bourdieu, 1996). É importante ressaltar que o termo "caminhada" é recorrente entre as lideranças.

Para Jesus, a posição, o lugar que uma pessoa toma diante da vida e das pessoas, é fundamental no anúncio de sua mensagem. A posição da pessoa diante da Vida fala mais do que suas palavras. Jesus anunciou a Boa Nova do Reino a partir dos marginalizados. Esta posição de Jesus leva os pés de chinelo a acreditar n'Ele e também ir atrás d'Ele. E diziam, Jesus é diferente. Ele está conosco. Sua palavra não é papo furado. (A Caminhada de Jesus, 1985, p.5, grifo da liderança).

Como já visto anteriormente, Jesus está a favor dos oprimidos, então, mais que falar e rezar por tais indivíduos marginalizados, a vida do fiel deve condizer com a caminhada de Jesus. Dito de outro modo, é importante alinhar "fé e vida", "oração e ação", como mostra o texto abaixo.

Outro objetivo da Boa Nova é nos levar a ficar unidos ao Pai, através da oração (Mc 1, 35). Uma atitude muito comum em Jesus é a oração. Às vezes ele deixava a multidão e se punha em oração. A ação não dispensa a oração e nem a oração dispensa a ação. Fé sem obras é morta $(\operatorname{Tg} 2,14)$. [...] A oração é assumir a vida que estou levando. É ver se essa vida está de acordo com o projeto de Deus. Oração é contemplar Deus na realidade. Não podemos reduzir a oração a uma simples conscientização. Fé e vida devem se misturar. Não podemos cair na tentação de batizar o ativismo como oração. O animador de comunidade e a própria comunidade que não fertilizarem seus trabalhos na intimidade com o Pai, não terão força para fazer a libertação. (A Caminhada de Jesus, 1985, p. 8, grifo da liderança). 
Há uma fronteira ideológica sobre "o que é ser cristão" que implica em responsabilidades e ação junto à sociedade. O senso de ter uma "missão" e firmar sua “conversão" frente aos outros fieis e à comunidade através do "testemunho" fortifica a noção de identidade pela diferença em relação aos grupos mais próximos. A rede de lideranças a quem dediquei minha atenção nesta pesquisa, está unida por experiências semelhantes, embora subjetivamente absorvidas de formas distintas, guiadas por uma moral religiosa que, mesclada à missão de anunciar a Boa Nova na fala e na ação, aprendeu estratégias de organização de atividades e eventos, de comunicação e de comportamento.

Dito isto, passamos adiante para aidentificação e análise destes elementos nos relatos das lideranças envolvidas nesse processo de interação e que constituem parte da rede de interconhecimento em questão.

\section{O "Ser PT" como uma identidade}

Aqui analisamos o significado atribuído à expressão "ser PT"pelas lideranças, não como uma filiação formal ao Partido dos Trabalhadores, mas sim como um discurso e prática moral que constitui uma identidade. Dito de outro modo, "ser PT" diz sobre uma trajetória, ou mesmo a "caminhada" do político, o que pode sugerir uma maior ou menor probabilidade de cooptação dentro do "jogo político". Isto porque o político de caminhada tem uma trajetória de "testemunho de vida", ou seja, de participação ativa seja na comunidade, no sindicato ou no partido. Nessa lógica, ao seguir o exemplo da "caminhada de Jesus", seria mais difícil de ser corrompido pela competitividade do âmbito político partidário, marcado pela divisão (Palmeira e Heredia, 2010).

Este grupo é particularmente constituído de camponeses, sendo que a categoria "PT rural" se configura como uma categoria nativa que remete à simplicidade, à humildade e à solidariedade do camponês, ainda mais evidente no camponês "cebista". Isto reforça duplamente estas dimensões, uma vez que o "PT rural, aquele pé de chinelo mesmo" fundado na Zona da Mata e Leste mineiro tem origem imbricada no Mobon/Ceb's.

É interessante perceber como termos utilizados nos cursos religiosos permanecem nas narrativas destas lideranças políticas em argumentos políticos, como o "candidato sem caminhada"; "o PT aqui é pé de chinelo mesmo", remetendo àelementos da moralidade religiosa como a humildade, a justiça social e a busca de trabalhos em favor dos oprimidos.

A compreensão do partido como o acúmulo de experiências na "luta por justiça social" édotada de uma lógica de união, solidariedade, humildade,que remete aos elementos de 
normas e princípios da moralidade religiosa. Nas narrativas, "Ser PT" remetia à uma identidade construída pelo contraste, pela oposição entre o "eles" e o "nós". Em que o "nós" remetia ao acúmulo de experiências, à "caminhada", às "lideranças de Deus" em missão na terra e, portanto, aquelas que não se deixam corromper facilmente, pois tem como foco o objetivo final, qual seja, o "reino de Deus" e a construção de uma sociedade mais justa e igualitária, o "bem comum", ou seja, elementos da dimensão das práticas orientadas pelos princípios condutores descritos acima. Nesse jogo de oposições, o outro é aquele que não passou por tais experiências, não passou pelo processo de formação de lideranças religiosas, sindicais e políticas.

Entretanto, mesmo entre as lideranças que fazem parte da mesma rede de interconhecimento (Weber, 2009) há uma diferenciação entre os que são reconhecidos pelo exemplo de vida e os que não se enquadram como modelos a serem seguidos.Implícita à busca pelo "bem comum" está a prioridade pelo bem do coletivo acima da satisfação individual. Este é um dos julgamentos feitos à membros do partido, em geral àqueles que chegaram posteriormente à fundação ${ }^{31}$, que não participaram da "caminhada".

A "caminhada" se refere à experiência desde as comunidades, passando pelos sindicatos e a fundação dos diretórios do partido. Uma caminhada de "testemunho" que remete aos ensinamentos sobre a "A caminhada de Jesus", tema foco de cursos que prescreviam um "ser no mundo", uma maneira de agir no cotidiano, de performar (Taylor, 2013) e, consequentemente, construir (Tambiah, 1985)o "Reino dos Céus". A busca por privilégios pessoais dados à proximidade ou a posição na administração municipal era mal vista por esse grupo de interlocutores, como argumenta uma liderança em relação ao pedido de apoio para negociar privilégios individuais juntamente ao prefeito, o que era visto por ela como desnecessários à atuação administrativa.

Assumindo que os discursos religiosos que traziam a "Boa Nova do Evangelho" são tratados como verdades e funcionam como normas, não no sentido de legislação, mas numa segmentação dual entre o que é normal e o que é anormal (Foucault, 1995), estabeleceu-se uma lógica de oposição entre "bom e mal", "rico e pobre", "grande e pequeno". O "nós", isto é, os políticos religiosos em questão, ao trazer a moralidade religiosa para o mundo da política (Kuschnir, 2007) se diziam governar a "favor dos pequenos" enquanto a oposição, constituída por "eles", governava "a favor dos ricos", “dos grandes".

\footnotetext{
${ }^{31}$ Para saber mais sobre a importância das gerações neste processo, ver Rabelo (2018).
} 
O choque entre moralidades distintas, como no âmbito religioso e no âmbito político partidário, foi vivenciado de formas distintas pelas lideranças. Com a mudança do contexto nacional e a experiência adquirida pela participação no jogo político partidário, tais lideranças religiosas, já acostumadas ao mundo do sindicato, percebem a necessidade da ampliação do partido, e de aceitarem novas filiações de pessoas que "não tinham uma ideologia assim de base", ou seja, não eram nem "cristão de verdade", nem "PT de verdade". Essa ampliação, ou "inchaço" como algumas relataram, é apontada como uma das causas do "enfraquecimento da base" e da crise política com o partido nos dias de hoje.

De forma semelhante, o realinhamento partidário seguindo a dinâmica política da construção da oposição a cada eleição municipal, não foi vista com bons olhos pelas lideranças mais tradicionais, já que a lógica da oposição entre o bem e o mal, o grande e o pequeno se viu desfeita em relações estabelecidas cotidianamente para se vencer as eleições.A eleição em pequenos municípios na Zona da Mata Mineira tem uma característica interessante no que diz respeito ao número de candidatos à prefeitura. De acordo com José Mariano ${ }^{32 \text { “'não }}$ adianta, cidade pequena não adianta não suporta ter três candidatos, não adianta que não vai". Esta constatação coloca dilemas a serem resolvidos, já que para que se consiga alcançar o cargo almejado, são necessárias coligações e realinhamentos partidários de modo que o município se polarize entre dois grandes lados opostos. Nem sempre as coligações necessárias no contexto local, são as idealmente desejáveis, embora seja as factíveis, dados conflitos ligados a relações familiares e cotidianos. É importante frisar que partidos políticos são constituídos de pessoas e em municípios pequenos, muitas vezes as pessoas já têm relações, tanto de conflito quanto de afinidade, preestabelecidas muito antes de entrar para o mundo da política.

Diante de um partido mais amplo, com relação ao inicial, a identidade de "ser PT", que está intimamente relacionada a um grupo de lideranças camponesas religiosas, cebistas e sindicalistas, já não se confunde com estar ou não formalmente filiado ao Partido dos Trabalhadores. Assim, estar filiado ao partido não é suficiente para ser considerado "PT de verdade" por aqueles que participaram na sua fundação municipal. Por não ter passado pela "caminhada" e aprendido a busca pela "justiça social" numa dimensão mais vivenciada e sentida do que falada e ouvida, políticos que se filiaram a partir da ampliação do partido são, muitas vezes, avaliados como não tendo "ideologia de trabalhador" e "sem projeto para os pequenos". Assim, na concepção de uma destas liderança fundadoras do STR's e do diretório

\footnotetext{
${ }^{32}$ José Mariano, 67 anos, relato concedido àLívia Rabelo em 25.07.16.
} 
do PT em seu município, ao remeter a um político municipal bastante conhecido e filiado ao partido, afirmou que o político "nunca foi PT de verdade" e argumenta que tal político se "apaixonou" pelo partido ao conhecer um dos deputados estaduais que fizeram parte do Movimento. Note que se "apaixonar" pela causa do partido não é suficiente para "ser PT de verdade", pois não se vivenciou a "caminhada".Mesmo dentro do movimento, é notável a diferença de tonalidade ao narrar a perseguição, entre as lideranças mais jovens. A conotação de quem se lembra ou soube é significativamente diferente de quem experienciou a perseguição, mas infelizmente, na tradução do oral para o escrito (Bauman e Briggs, 2006; Vansina, 2010) perdemos a dimensão do sensorial, nos resta registrar a diferenciaçãoentre os que viveram, em menor ou maior grau, a perseguição e o sofrimento político inicial.

Se por um lado, há políticos filiados ao partido que não são considerados "PT de verdade" pelos fundadores, por outro lado, há políticos fundadores que já não estão filiados ao partido que se sentem parte do Partido dos Trabalhadores. Entre as lideranças desfiliadas se encontra o argumento "nós saímos do PT, mas o PT não saiu da gente" ao justificar que os projetos pensados e efetivados por eles tinham como público os "pequenos", os trabalhadores rurais. $\mathrm{O}$ argumento dado mostra como a filiação é menos importante que a forma de agir no mundo, tanto a nível micropolítico, como a nível macropolítico. Mais importante que estar filiado ao Partido dos Trabalhadores é ter os princípios morais constituídos ao longo da trajetória com base na moralidade religiosa, ter projetos que beneficiem os "oprimidos" e busquem "fazer o bem" na medida do possível, dada a especificidade do contexto local.

O fato de não estar filiado ao partido, não quer dizer que lideranças não se sintam "PT". Para algumas lideranças a desfiliação foi efetivada por se sentirem "decepcionados" com integrantes do partido e suas atitudes que foram vistas pelas que saíram como "perda de princípios" tanto a nível da micropolítica como a nível organizacional do partido. Os argumentos seguem na direção de "a gente já não tava fazendo como era", "por isso que tá desse jeito, foi perdendo seus princípios" são frequentes. Essas narrativas remetem ao princípio da união, do trabalho como cooperação e não competição, da valorização do coletivo, como visto nos cursos de Aprofundamento e Revisão.

Dessa forma, ser ou não PT diz mais sobre a construção de uma identidade de "PT rural" ou "PT puro", do que sobre questões burocráticas e institucionais de filiação. A ênfase na manutenção dos princípios pelos quais o diretório do partido foi fundado em cada município é uma tônica em muitos relatos críticos como 
[...]aquilo que a gente pregou que queria ser, libertação pro povo, daí a pouco nos tamo virando cabide de emprego, tamo só recebendo salário e, e... vendo ali as pessoas né, dois mandato, três mandato, num abrindo mão disso... eu, eu, como... eu sempre questionei essas coisas né. (Joaquim Pedro, relato concedido à Lívia Rabelo 24.02.18)

$\mathrm{O}$ relato acima mostra uma autocrítica ao remeter à missão de reestabelecer a justiça social incorporada da moralidade religiosa que foi "esquecida" por algumas lideranças políticas que se perpetuam no poder, não tendo a humildade de apoiar a formação de novas lideranças para seguir o processo iniciado.

A dimensão moral de receber o salário sem o diálogo com a base do movimento também é posta em cheque, já que havia um imaginário do que seria o envolvimento político partidário destas lideranças religiosas e sindicalistas, ou seja, com menor ou maior grau de consenso, havia um projeto inicial de busca pela "justiça social”. Se questiona o princípio da humildade, já que lideranças estabelecidas em seus cargos já não "ouvem” mais as bases como pode ser percebido no relato de Joaquim Pedro ${ }^{33}$ "E sempre questionei também, né, os deputados que a gente já tinha, né, que não tinha de fato esse compromisso, esse olhar pelas bandeiras que a gente defende". Compreendemos aqui uma queixa à falta de diálogo com a base, com as minorias, "os oprimidos", de forma queelementos como o "saber ouvir e construir juntos" pode ter se perdido em algumas caminhadas.

Através de elogios e queixas, ou seja, do vigiar e narrar (Comerford, 2014), do mapeamento (2003) feito pelas lideranças fundadoras de diretórios do Partido dos Trabalhadores, especificamente rural a princípio, busquei compreender como elementos constituintes da moralidade religiosa no Mobon/Ceb's, não somente seguem presentes nas narrativas e argumentos políticos destas lideranças, como também, são constituintes de uma identidade de "ser PT". O que se há de reter desta argumentação é a que o "ser PT" rural, não significa estar filiado ao partido, mas sim uma forma de agir no mundo, baseada na moralidade religiosa do Mobon/Ceb's que orientou a conduta durante toda a trajetória desde a formação/dinamização das comunidades, criação dos sindicatos dos trabalhadores rurais e dos diretórios municipais do Partido dos Trabalhadores.

\footnotetext{
${ }^{33}$ Joaquim Pedro, relato concedido à Lívia Rabelo 24.02.18.
} 


\section{Considerações finais}

Partimos de uma abordagem histórico-processual para compreender como elementos constitutivos da moralidade religiosa do Movimento da Boa Nova se relacionavam com a identidade do "ser PT" para lideranças camponesas da Zona da Mata Mineira.

Compreendo a construção desta identidade como um processo que se inicia a partir das experiências, sociabilidade e redes de interconhecimento potencializadas pelo Mobon, passando pelas experiências sindicais, a perseguição política e fundação dos diretórios do Partido dos Trabalhadores nos pequenos municípios onde as lideranças religiosas eram influentes. Assim, "ser PT" diz mais sobre um acumulo de experiências que constrói e reconstrói o sujeito, dada a dinamização da vida cotidiana, que a filiação do sujeito ao Partido dos Trabalhadores. Lideranças que passaram por tais experiências relatam que alguns filiados "nunca foram PT de verdade", enquanto lideranças que ajudaram a fundação do partido a nível municipal e já não se encontram filiadas afirmam que "nós saímos do PT, mas o PT não saiu da gente".

Assim, identificamos elementos constituintes da moralidade religiosa do Mobon, a partir de documentos históricos, que estão presentes nos relatos das lideranças sobre o que chamei aqui de "ser PT" quando argumentam uma escolha tomada no passado com "eu tenho meus princípios", “a gente já não tava fazendo como era", "por isso que tá desse jeito, foi perdendo seus princípios", etc.

Segmentamos os elementos em duas dimensões: uma mais abstrata, no sentido de ser uma orientação cosmológica, como os princípios de união, solidariedade, humildade e justiça social; e outra mais concreta já que diz respeito à conduta do sujeito no mundo, como a responsabilidade social, a conversão e o testemunho de vida.

Sugerimos, então que, em face da fundação dos diretórios do Partido dos Trabalhadores nos municípios em questão terem sido criados por lideranças sindicais, que por sua vez advêm das comunidades eclesiais de base criadas e/ou dinamizadas pelo Movimento da Boa Nova, parte do projeto político de fundação do PT diz respeito ao projeto religioso de criação do "Reino dos Céus". Dito isso, argumento que, para muitas destas lideranças que passaram por esse núcleo de experiências, "ser PT de verdade" remete aos elementos da moralidade religiosa do Mobon. 


\section{Referências}

ARAÚJO, Ricardo Torri. O Movimento da Boa Nova. Belo Horizonte: Editora O Lutador, 1999.

BAUMANN, Richard, and BRIGGS, Charles. Poética e Performance como perspectivas críticas sobre a linguagem e a vida social. Ilha Revista de Antropologia, v. 8, n. 1,2, p. 185229, 2006.

BOURDIEU, Pierre. Descrever é prescrever: as condições de possibilidade e os limites da eficácia política. In: A Economia das trocas Linguísticas: o que falar quer dizer.São Paulo: Editora da Universidade de São Paulo, 1996, p. 117-126.

CARSTEN, Janet et al..Cultures of relatedness: New approaches to the study of kinship. Cambridge University Press, 2000.

CINTRÃO, Rosângela P. ONGs, Tecnologias alternativas e representação política do campesinato: uma análise da relação entre o Centro de Tecnologias Alternativas e os Sindicatos dos Trabalhadores Rurais na Zona da Mata Mineira. Rio de Janeiro: UFRRJ, 1996. COMERFORD, John Cunha. Como uma família: sociabilidade, territórios de parentesco e sindicalismo rural. Rio de Janeiro: RelumeDumará: Núcleo de Antropologia da Política/UFRJ, 2003.

Vigiar e narrar: sobre formas de observação, narração e julgamento de movimentações. Revista De Antropologia, v. 57, n. 2, p. 107-142, 2014.

FOUCAULT, Michel. Vigiar e punir: nascimento da prisão; tradução de Raquel Ramalhete, Editora: Vozes, 2010.

FREIRE, Paulo. Pedagogia da autonomia: saberes necessários à prática educativa. 34. Ed. São Paulo: Paz e Terra, 1996.

HEINTZ, Monica. The anthropologyofmoralities. Editora: Berghahn Books, 2009.

HOWELL, Signe. The EthnographyofMoralities. Editora: Taylor \& Francis, 2005.

KERANDEL, Jean; DEL CANTO, Luis Mario. Evangelizacion y promocionen Comunidades Eclesiales de Base (medio rural), Brasil. Medellín, Instituto Pastoral del CELAM, 1977.

KUSCHNIR, Karina. Antropologia e política. Revista Brasileira de Ciências Sociais, v. 22, n. 64, p. 163-167, 2007.

OLIVEIRA, Fabrício Roberto Costa. Religião, política e comunidade: emergência e politização do Movimento da Boa Nova. Tese (Doutorado em Ciências Sociais em Desenvolvimento, Agricultura e Sociedade) - UFRRJ, Rio de Janeiro, 2012. Orientação de Regina Ângela Landim Bruno.

PALMEIRA, Moacir e HEREDIA, Beatriz. Política Ambígua. In:

Política

Ambígua.Rio de Janeiro: Editora Relume-Dumará: NUAP, 2010.

RABELO, Lívia. O Processo de formação religiosa e política do Movimento da Boa Nova.

Relatório de iniciação científica (Licenciatura em Ciências Sociais). Universidade Federal de Viçosa, Viçosa, 2017.

RABELO, Lívia. Análise de método de organização religiosa e política do Movimento da Boa Nova. In: 42o. Encontro Anual da ANPOCS, Caxambu, 2018.

SAGRADA, Bíblia. Tradução dos originais grego, hebraico e aramaico mediante a versão dos monges Beneditinos de Maredsous (Bélgica). São Paulo: Editora Ave-Maria, 2016.

TAMBIAH, Stanley J. A Performative Approach to Ritual In:

Culture, Thought, and Social Action. Cambridge, Mass.: Harvard University Press, p. 123-166, 1985.

TAYLOR, Diana. Traduzindo Performance. In: DAWSEY, John et al. Antropologia e Performance. São Paulo: Terceiro Nome, 2013, p. 9-16.

TEIXEIRA, Ramon da Silva. Sindicalismo rural em Espera Feliz/MG: história, reuniões e eixos-articuladores de sua prática política. 2017. 59 f. Monografia (bacharelado em Ciências Sociais) - Universidade Federal de Viçosa, Viçosa. 
VANSINA, Jan. A tradição oral e sua metodologia.In: História geral da África, p. 157-179, 2010.

WEBER, Florence. Trabalho fora do trabalho: uma etnografia das percepções. Rio de Janeiro: Garamond, 2009. 


\title{
Observando coisas, desvelando políticas de conhecimento: a edificação da identidade militante católica de agentes da cultura das CEBs
}

\author{
Observing things, unveiling knowledge policies: the building of the catholic militant identity \\ of agents of the culture of the CEBs
}

\author{
Ramon da Silva Teixeira ${ }^{34}$ \\ ramoneps2014@gmail.com \\ Lívia Rabelo ${ }^{35}$ \\ lih.rabelo@gmail.com
}

\begin{abstract}
Resumo: Este trabalho propõe-se a realizar dois movimentos. Primeiro, demonstrar a força do ato de seguir as coisas que compõem o sistema de aprendizagem do Movimento da Boa Nova (Mobon), i.e., observar os objetos cujo significados estão condicionados pelas transações, atribuições e motivações dos agentes das Comunidades Eclesiais de Base (CEBs) dinamizadas pelo Mobon. Depois, explicitar que, tomados pela perspectiva da análise ritual, as coisas são objetos bons para pensar. São objetos de memória e desvelam políticas de conhecimento dizem sobre experiências vividas, modos de transmissão de conhecimento, construção de identidade e (re) invenção da tradição. Assim, entender a relação estabelecida entre pessoas e coisas nos fornece pistas sobre a construção de uma identidade militante católica.
\end{abstract}

Palavras-chave: CEBs. Mobon. Política de conhecimento. Identidade militante católica.

Abstract: This work it is proposed to perform two movements. First, to demonstrate the force of following the things that make up the learning system of the Movimento da Boa Nova (Mobon), i.e., to observe the objects whose meanings are conditioned by the transactions, attributions and motivations of the agents of the Basic Ecclesial Communities (CEBs, in the abbreviation in Portuguese) guided by Mobon. Then to explain that, taken from the perspective of ritual analysis, things are good to think. They are objects of memory and reveal knowledge policies, that is, they say about experiences lived by real social actors, their modes of transmitting knowledge, building identity and (re) inventing tradition. Thus, understanding the relationship established between people and things gives us clues about building a militant catholic identity.

Key-words: CEBs. Mobon. Knowledge policies. Catholic militant identity.

\section{Introdução: O que são coisas e que coisas observar...}

Entre tantos esteios que lhes dão sustentação, fundamenta as Ciências Humanas e Sociais o paradigma indiciário (Ginzburg, 1990). Assim, não é de hoje que a operação de

\footnotetext{
${ }^{34}$ Licenciado em Letras pela Fafile/UEMG, bacharel em Ciências Sociais pela Universidade Federal de Viçosa (UFV) e mestrando em Antropologia Social pelo Mestrado Interinstitucional entre a Universidade Federal do Rio de Janeiro e a Universidade Federal de Viçosa (MINTER MN/UJRJ/DCS/UFV), é orientado por John Cunha Comerford (PPGAS/MN/UFRJ) e co-orientado por Fabrício Roberto Costa Oliveira (DCS/UFV).

${ }^{35}$ Mestre em Economia pela Universidade Federal do Ceará (UFC), mestranda em Antropologia Social pelo Mestrado Interinstitucional entre a Universidade Federal do Rio de Janeiro e a Universidade Federal de Viçosa (MINTER MN/UJRJ/DCS/UFV), bacharel em Ciências Econômicas e licenciada em Ciências Sociais pela Universidade Federal de Viçosa (UFV).
} 
observar objetos, coisas, mercadorias e materiais apontam caminhos metodológicos e analíticos para um de seus ramos, a Antropologia Social. Desde os clássicos é possível notar a importância dada ao exame da "multiplicidade de coisas sociais em movimento" (Mauss, 2003, p.187) e sua capacidade heurística para o entendimento de fenômenos sociais (e culturais) totais. Os exemplos mais conhecidos são as investigações empreendidas por Malinowski (1984) e Mauss (2003). O primeiro nos oferece a descrição do kula, o circuito ritual de trocas de colares (soulava) e braceletes ( $m$ wali) entre os melanésios da Nova Guiné. O segundo, ao observar as prestações e contraprestações de bens de prestígio e comida por um chefe-anfitrião para convidados formalmente chamados para darem sua validação pública a prerrogativas familiares entre tribos do noroeste americano, coloca à disposição dos pesquisadores a noção de Potlatch.

Mais recentemente, os objetos ou as coisas têm sido acionadas por uma "Antropologia das Coisas" e do Consumo a fim de que se reflita sobre a relação entre mercadorias, cultura e as políticas de conhecimento de grupos e sociedades humanas (Appadurai, 2008; Kopytoff, 2008; Douglas \& Isherwood, 2004, Ingold, 2012 entre outros). Parte-se do "ponto de vista metodológico [de que] são as coisas em movimento que elucidam seu contexto humano e social" (Appadurai, 2008, p.17, grifo do autor). Como explicita Menezes (2013),

\begin{abstract}
(...). Os objetos, ou as coisas, têm sido valorizados por seu potencial heurístico na interpretação das relações entre o corpo, os sentidos e as materialidades; na reformulação das concepções sobre a relação sujeito/objeto; por seus processos de transformação (que envolvem formas de produção, modalidades de troca e práticas de uso e consumo); e ainda quanto à análise de políticas e práticas de conservação, exposição e patrimonialização (p.235).
\end{abstract}

No estudo da religião e da cultura popular, não é diferente. No Brasil, por exemplo, há um largo percurso de observação de coisas e suas respectivas materialidades realizada por uma série de antropólogas e antropólogos que buscam construir uma Antropologia da Devoção $^{36}$ e da Cultura Popular a partir da investigação de "expressões materiais que visibilizem emoções, entidades, cosmologias, para compreender as relações mais profundas articuladas em torno de elementos de cultura material" (Menezes, 2011, p.46; cf. também, Menezes, 2004, 2013, 2017; Brandão, 1999; Lima, 2015; Bitter, 2013 entre outros).

\footnotetext{
${ }^{36}$ Isto é, uma antropologia voltada para o estudo do catolicismo popular ou culto aos santos (Menezes, 2011).
} 
Apesar dessa larga tradição, essa maneira de proceder se mostra como uma novidade $^{37}$ para a pesquisa etnográfica que o primeiro autor desse trabalho está desenvolvendo, em que investiga a relação entre as Comunidades Eclesiais de Base (CEBs), o Movimento da Boa Nova (Mobon) ${ }^{38}$ e a formação bíblico pastoral popular que se desdobrou, em alguns casos, no engajamento político-social, em seu sentido mais amplo, de grupos de pessoas de comunidades rurais e urbanas de algumas regiões de Minas Gerais ${ }^{39}$.

A pesquisa de mestrado a que nos referimos possui o objetivo de mapear o conjunto de práticas educativas comuns de "fazer a luta" e analisar os diferentes modos como são apropriadas e ressignificadas essas práticas pelos agentes das CEBs (isto é, tanto aqueles que atuam no âmbito das comunidades como "leigos/as", quanto daqueles que são "filhos/as de CEBs" e hoje atuam em outros campos, como no político-institucional). Uma questão posta dentro desse universo de investigação foi pensar o modo como o que se está chamando de sistema de aprendizagem ${ }^{40}$ dinamizado pelo Mobon foi/é incorporado, reproduzido e ressignificado geracionalmente ${ }^{41}$.

\footnotetext{
${ }^{37}$ Agradecemos a Renata Menezes e a Raquel Lima, antropólogas e professoras que nos ministraram a disciplina "Rituais, jogos, performances e simbolismo", pela contribuição para a emergência dessa nova forma de ver a realidade e tratar os dados etnográficos. Gratidão especial a Renata, pela leitura de alguns ensaios, pelos comentários e pela indicação de bibliografias.

${ }^{38}$ Fundado pelos missionários sacramentinos de Nossa Senhora, na Diocese de Caratinga no final da década de 1960. Trata-se de um movimento católico de evangelização que parte de um método pastoral (Araújo, 1999) ou um método de formação bíblico teológica popular continuada que se dá a partir de cursos de formação de lideranças (cursos de Pré-Boa Nova, Boa Nova, Campanha da Fraternidade e Mês da Bíblia nas casas de curso da Igreja Católica) e cursos de base (nas comunidades). Os objetivos principais do movimento são a criação e manutenção de comunidades e a formação de lideranças.

${ }^{39}$ Inicialmente o foco era na Zona da Mata mineira, todavia, durante a pesquisa de campo, circulou-se por outras regiões do estado. Assim, a etnografia em construção trata-se de uma "etnografia multisituada" (Marcus, 1995). Em nível de organização de "governança da Igreja", foram vivenciados diversos speech events nas dioceses de Caratinga, Mariana, Governador Valadares e Itabira/Coronel Fabriciano.

${ }^{40}$ Sistema de aprendizagem porque composto por uma miríade de aprendizagens, que relacionados e em sua unidade, compõem o "método do Mobon". Até o momento, etnograficamente, mapeou-se as seguintes aprendizagens/práticas educativas: a comunicação por metáforas e parábolas; a prática da escuta mútua (entrereligiosos-e-leigos-no-cursos, entre-leigos-e-leigos-nos-cursos, entre-leigos-e-leigos-na-comunidade e entreleigos-e-religiosos-em-algumas-paróquias); o uso de desenhos; o uso de místicas; o uso de festejos-festas populares de devoção; o uso de filmes; o uso de fotos; o uso de música; o uso do teatro; o uso de novas mídias e das redes sociais; o uso de registro escrito; o estudo popular da bíblia e dos livros de conhecimento da Igreja Católica; o uso de mapas; e a ritualização do cotidiano.

${ }^{41} \mathrm{O}$ foco é entender como se deu o processo de ensinar/aprender de agentes da cultura das CEBs originalmente dinamizadas pelo "método do Mobon" e qual sua importância para (i) a superação do "analfabetismo bíblico"; (ii) para a formação de lideranças comunitárias; e, (iii) para a organização social e política em "comunidades", sobretudo, dos camponeses de algumas regiões de Minas Gerais. Pretende-se responder às seguintes questões: Quais os valores que fundamentaram o método do Mobon? Como esse método se desenvolveu? Como ele foi difundido, isto é, como circulou pelas várias localidades de Minas Gerais? Como ele foi reproduzido de geração em geração? Como esse método foi incorporado, reapropriado e ressignificado por cada geração e em diferentes espaços eclesiais e, sobretudo, em situações de formação do campo político?
} 
Para responder a essa questão observou-se durante a pesquisa de campo ${ }^{42}$ eventos (speech events), símbolos rituais, documentos de diversas naturezas, anotações feitas pelos agentes da cultura entre tantos outros indícios que forneceram pistas para a interpretação das situações. Todavia, em razão do reduzido espaço para a exposição de todo o trabalho desenvolvido até o momento, em busca de respostas para a questão, propõe-se aqui realizar uma análise, a princípio ensaística, de parte da cultura material que integra o sistema de aprendizagem do Mobon. Assim, procura-se utilizar da faculdade heurística expressa na relação entre as coisas e a formação de pessoas e vice-versa. O trabalho versará, portanto, sobre o papel da cultura material na aprendizagem e na construção de identidades (Rinaldi et al., 2013). Nomeadamente, na edificação da identidade militante católica de cebistas que tiveram contato, direta ou indiretamente, com o Mobon.

Antes de prosseguirmos para a exposição da relação estabelecida entre pessoas e coisas na construção de uma identidade militante católica, iremos nos debruçar em uma breve discussão sobre a definição de coisa sob a qual estamos enquadrando a análise dos "materiais adquiridos" e/ou observados durante o giro etnográfico por algumas dioceses de Minas Gerais.

Como demonstrou Mauss (2003), a propósito da troca dos taonga ${ }^{43}$ entre os maoris da Polinésia, "todas as propriedades rigorosamente ditas pessoais têm um hau ${ }^{44}$, um poder espiritual” (p.199). Dessa forma

(...) é que a coisa recebida não é inerte. Mesmo abandonada pelo doador, ela ainda conserva algo dele. (...). No fundo, é o hau que quer voltar ao lugar de seu nascimento, ao santuário da floresta e do clã e ao proprietário. (...) é nítido que, em direito maori, o vínculo pelas coisas, é um vínculo de almas, pois a própria coisa tem uma alma, é alma. Donde resulta que apresentar alguma coisa a alguém é apresentar algo de si. (...). Enfim, a coisa dada não é uma coisa inerte (p.199-200, grifos nossos).

Partindo desse pressuposto (clássico) inicial é que queremos conceber as coisas de que trataremos aqui. Isto é, as coisas são vivas, elas possuem um hau; uma biografia (Kopytoff,

\footnotetext{
${ }^{42}$ Realizada entre dezembro de 2017 a julho de 2018.

${ }^{43}$ Plural de tonga. Designa em particular, no direito maori, as esteiras de casamento que as filhas herdam ao se casarem, além de adornos, talismãs que são trazidos pela mulher para a família recém fundada. Esses objetos, "mais ligadas ao solo, ao clã, à família e à pessoa" (Mauss, 2003, p.196), possuem a condição de reciprocidade. O sentido pode ser estendido "em maori, em taitiano, em tongan e mangarevan, tudo o que é propriedade propriamente dita, tudo o que pode ser trocado, objeto de compensação. São exclusivamente os tesouros, os talismãs, os brasões, as esteiras e os ídolos sagrados, às vezes também as tradições, cultos e rituais mágicos" (idem, p.196-197).

44 Designa o "espírito das coisas". Como no latim spiritus, qualifica ao mesmo tempo o vento e a alma. Especificamente, em certos casos, diz da alma e do poder das coisas inanimadas e vegetais.
} 
2008); uma política de valor que são "muitas vezes políticas de conhecimento" (Appadurai, 2008, p.19) que lhes são atribuídas nas transações (circulação, troca, conservação, exposição, tombamento etc.) e nas relações objeto-pessoa. Tornam-se com o passar do tempo signossímbolos que condensam e comunicam mensagem sociais. Assim, um mero objeto inanimado, inerte, transforma-se em coisa, que na concepção vitalista ingoldiana se caracteriza por ser "porosa e fluida, perpassada por fluxos vitais, integrada aos ciclos e dinâmicas da vida e do meio ambiente" (Ingold, 2012, p.25), cujo significado está necessariamente ligado, ou melhor, condicionado pelos significados que lhes conferem as transações, atribuições e motivações humanas. Em outras palavras,

(...). A coisa, por sua vez, é um “acontecer", ou melhor, um lugar onde vários aconteceres se entrelaçam. Assim, observar uma coisa não é ser trancado do lado de fora, mas ser convidado para a reunião [de vidas]. (...). Se pensamos cada participante como seguindo um modo de vida particular, tecendo um fio através do mundo, então talvez possamos definir a coisa, como eu já havia sugerido, como um "parlamento de fios" (Ingold, 2007b, p. 5). Assim concebida, a coisa tem o caráter não de uma entidade fechada para o exterior, que se situa no e contra o mundo, mas de um nó cujos fios constituintes, longe de estarem nele contidos, deixam rastros e são capturados por outros fios noutros nós. Numa palavra, as coisas vazam, sempre transbordando das superfícies que se formam temporariamente em torno delas (Ingold, 2012, p.29).

Por fim, “coisas materiais, assim como pessoas, são processos (Ingold, 2012, p.35). Elas possuem um ponto de vista ${ }^{45}$ que pode ser lido e servir de base, por exemplo, para a construção do conhecimento acerca da distinção (Bourdieu, 2007) de um grupo ou sociedade. Através da virtuosidade semiótica inerente, as coisas nos informam traços distintivos sobre sua produção, circulação, uso e consumo, e consequentemente, assinalam complexas mensagens sociais (Appadurai, 2008). Assim, quando falamos em observar as coisas, não nos propomos a fazer uma Antropologia das Coisas, mas demonstrar a importância da observação de "matéria em fluxo" (Ingold, 2012) como compósito na construção de um conhecimento acerca do que estamos nomeando como sistema de aprendizagem de um movimento católico de evangelização popular (o Mobon) que dinamiza CEBs em diversas dioceses mineiras, sobretudo, na Diocese de Caratinga. Trata-se, portanto, de promover um "jogo de escala" a fim de se gestar um tipo específico de conhecimento sobre um mesmo objeto de pesquisa ${ }^{46}$. Parte-se do pressuposto de que é

\footnotetext{
${ }^{45}$ Para o desenvolvimento dessa noção, a leitura de Viveiros de Castro (2002) a respeito do perspectivismo na América indígena foi inspiradora.

46 Tal como Menezes (2017), aproprio-me da ideia de Jacques Revel de jogos de escala. "Revel, na introdução de seu livro de 1996, enfatiza que a opção por escalas de análise mais ou menos amplas produzem resultados diferentes. Não apenas mais ou menos restritos, mas bastante diferentes: 'A escolha de uma escala particular de observação produz efeitos de conhecimento, e pode ser posta a serviço de estratégias de conhecimentos. Variar a
} 
[...] preciso assumir a ideia da religião como uma rede de relações e interações envolvendo o céu e a terra, ligando pessoas, santos, anjos, demais personagens da esfera celeste e a própria Trindade. E incluir nessas redes, também, as coisas, os elementos da cultura material, dentre as quais os santinhos [e as coisas de que trata esse artigo], sejam como mediadoras dessas ligações, sejam como seus agentes efetivos (Menezes, 2011, p.62).

Por fim, imbuídos pela dimensão cultural da análise religiosa (Geertz, 2008a) e certos da "capacidade de condensação de determinados objetos - que concentram ações e significados torna[ndo]-os pontos estratégicos para a análise de expressões religiosas" (Menezes, 2011, p.46), apostamos na observação e trato dos materiais que compõem o sistema de aprendizagem referido. Assim, as coisas de que falamos, são coisas que dizem da política (e da po-ética!) de conhecimento de agentes de CEBs que testemunham um catolicismo plural (Teixeira \& Menezes, 2009) que se reinventa ao longo do tempo através de geração em geração. Através dele, os agentes (re)criam sua identidade, sua distinção em face dos vários católicos e catolicismos (Teixeira, 2009) existentes em algumas regiões de Minas Gerais.

\section{Quando as coisas falam: breves apontamentos sobre elementos que circundam a prática} militante católico-política dos agentes das CEBs dinamizadas pelo Mobon

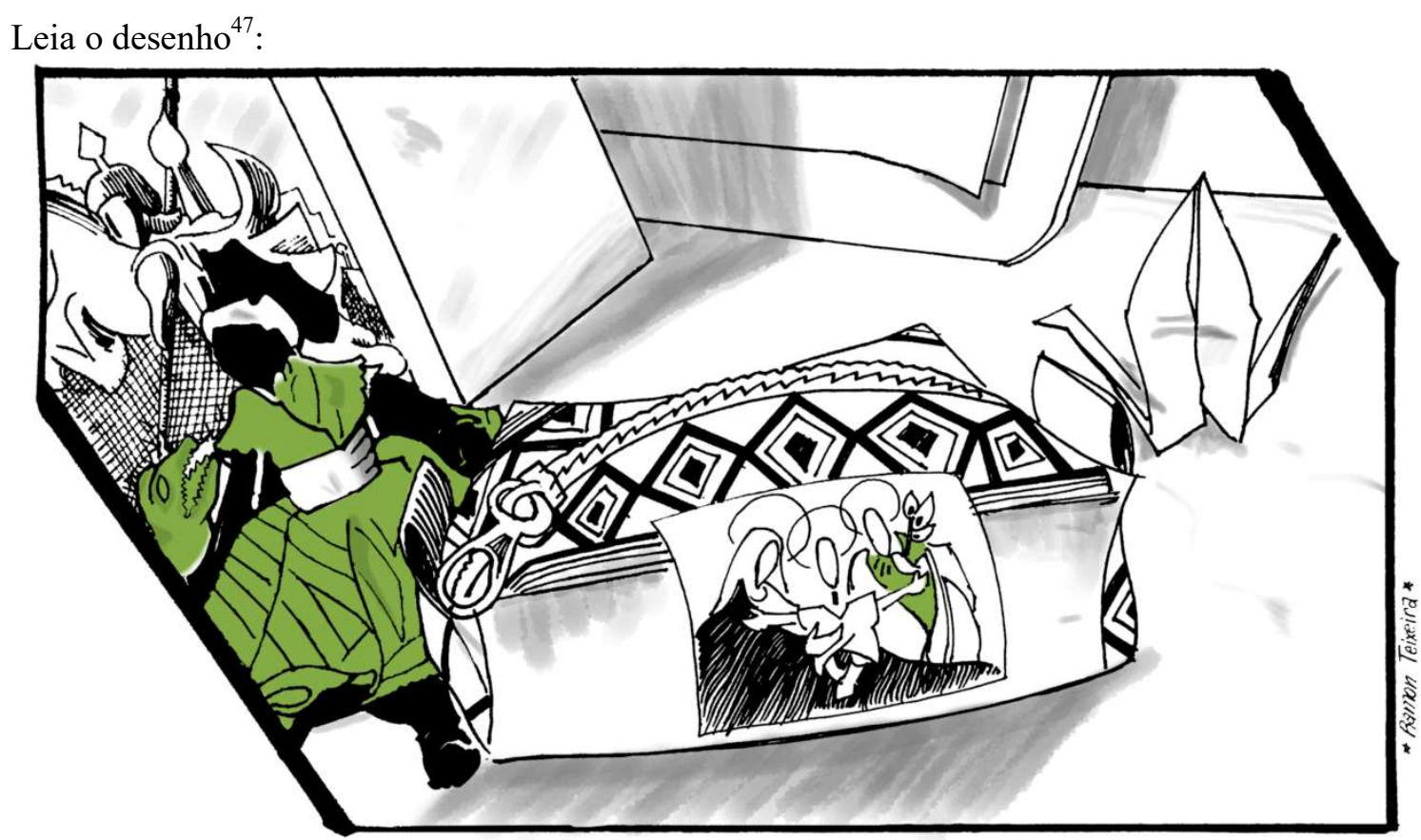

objetiva não significa apenas aumentar (ou diminuir) o tamanho do objeto, significa modificar sua forma e sua trama' (REVEL,1996: 20)" (Menezes, 2017, p.3). Assim, a partir dos "jogos de escala... reconstroem-se um objeto de estudo" (idem, p.4).

${ }^{47}$ Desenho feito pelo primeiro autor no dia 09/09/2018. Agradecemos a Pedro Paulo Faé pelo tratamento digital dado ao desenho e a algumas fotos que compõem esse trabalho. Por fim, para uma discussão da antropologia pelo desenho, cf. Kuschnir (2016). 
$\mathrm{Na}$ operação de observar atentamente as coisas dispostas em acima de uma estante para desenhá-las, enquanto se riscava a folha branca com lápis, canetas nankin de pontas variadas, caneta multiuso permanente ponta média, marcador permanente ponta chanfrada e canetão hidrocor na cor Apple Green (para os destaques) foi quando se intensificou o insight sobre a biografia das coisas. À frente, no primeiro plano, vê-se três itens que possuem um hau que muito dizem sobre a "floresta de símbolos" (para mencionar Turner, 2005) de onde foram extraídos (e para onde, teoricamente, querem retornar), e consequentemente, sobre a identidade militante católica de alguns grupos de agentes de CEBs com que se estabeleceu relações de interação.

No desenho de observação ${ }^{48}$ é possível ver artefatos simbólicos, ou, objetos rituais, que possuem significados distintos e ao mesmo tempo conectados. A maioria deles se origina de diversos eventos performados (Dawsey, 2005; Schechner, 2012; Taylor, 2013; Bauman \& Briggs, 2006; Silva, 2005) dos quais participou e observou o primeiro autor. Da esquerda para a direita, tem-se três lembrancinhas: a Abayomi $^{49}$, boneca de retalho originária da cultura afroameríndia, foi dada ao fim do $11^{\circ}$ Fórum de Promoção pela Igualdade Racial (FOPPIR), em Cataguases, no dia 19/11/2017, possui o significado de representar a resistência, a memória e a esperança. A bolsinha com a estampa da Sagrada Família, foi presenteada aos "facilitadores" das conversas durante o $7^{\circ}$ Encontro Diocesano de Formação de Leigos e Leigas da Diocese de Itabira-Coronel Fabriciano, em Ipatinga, no dia 08/07/2018. Por fim, o Tsuru, origami feito em página de revista, foi recebido no Curso de Férias de Educadores Populares, em Caratinga, no dia 14/01/2018.

Quando abordada de seu ponto de vista biográfico (Kopytoff, 2008), cada uma dessas coisas é única. Tratam-se de objetos imanados nas e pelas relações sociais que atuaram. Tornaram-se materiais portadores de memórias dinâmicas. Quer dizer, condensam recordações sempre abertas ao presente, levando-se em consideração a sua permanente potencialidade de afetar; de dinamizar conversas e gerar conhecimento.

Tomados pela perspectiva de análise fundamentada na noção de ritual (Peirano, 2001), os eventos e seus correligionários, os objetos rituais são objetos bons para pensar. Eles desvelam experiências vividas por atores sociais reais, seus modos de transmissão de conhecimento, construção de identidade e de (re) invenção da tradição que,

\footnotetext{
${ }^{48}$ Desenho de observação é aquele onde se utiliza de um modelo real para o desenvolvimento da percepção visual, isto é, a capacidade de observação de forma, luz e volumes. É um tipo de desenho onde se exercita a faculdade de olhar de fato para aquelas coisas que, de tão familiares, acabam passando despercebidas aos olhos. In: <http://dicasdepintura-defatima.blogspot.com/2011/07/o-que-e-desenho-de-observacao.html >. Acesso em 19 nov. 2018.

${ }^{49}$ Que significa "encontro precioso" em iorubá.
} 
consequentemente, influenciam a sociedade global (Menezes, 2009, p.180 e 193; Valeri, 1994). Notadamente, essas coisas, cada uma a partir de sua trajetória biográfica, diz sobre um modo de ser e fazer Igreja Católica próprio de cebistas que tiveram contato com o Mobon ${ }^{50} \mathrm{e}$ outras formações baseadas na Teologia da Libertação.

Desde as primeiras imersões à campo, as coisas que circulavam entre um evento e outro funcionaram como sinais de observação e interpretação (Ginzburg, 1990) que conectavam uma situação de interação a outra. Para os eventos sempre eram levadas algumas coisas (caderno de campo e outras ferramentas de registro e memória, livros e cartilhas, instrumentos ${ }^{51}$, ora ia-se vestido com camisas "do movimento" de outros eventos etc.) que dinamizavam conversas e situações, e sempre se retornava para casa com algumas outras coisas (souvenirs, cartilhas, cadernos do participante, outras camisas, jornais, cartazes, panfletos, embornais, canecas, crachás etc.). Não era diferente com os "leigos/as" e com os "filhos de CEBs", afinal, eles também faziam circular um conjunto diverso de materiais por onde passavam, criando "rastros... [que] são capturados por outros fios noutros nós" (Ingold, 2012, p.29).

Nesta sessão, portanto, por "coisas", queremos designar os objetos colocados em trânsito, utilizados durantes os eventos nas místicas, na composição de cenários; os materiais didáticos e de formação (livros, cartilhas, cadernos do participante, folders, Bíblia Sagrada etc.); as lembrancinhas (souvenirs); cadernos de anotação; entre outros artefatos recebidos ou coletados nos eventos em que se participou que serão utilizados como referência no presente trabalho.

Em recolhimento, concomitante ao momento de escrever ${ }^{52}$, organizavam-se os objetos, registravam-se em fotos e arquivava/guardava-se tudo o que vinha do campo para o "gabinete". Para cada situação de campo, foram criadas pastas no computador que receberam o nome de "materiais adquiridos" e em uma estante abarrotavam-se de lembranças vindas de todos os cantos. Assim acumulou-se uma diversificada coleção de coisas que merece ser

\footnotetext{
${ }^{50}$ Corrobora com essa constatação o fato de em todos os eventos de onde se originam as coisas retratadas no desenho contarem com agentes de CEBs que tiveram contato, direto ou indireto, com as formações do Mobon. Por exemplo, dentre os muitos agentes organizadores, o $11^{\circ}$ FOPPIR contou com a contribuição e participação de Agentes Pastorais Negros (APNs) e de integrantes da Pastoral da Juventude Rural, do Movimento Fé e Política de Manhumirim e Manhuaçu, da Pastoral Afro-Brasileira da Arquidiocese de Mariana, que tiveram contato, direto ou indireto, com as formações do Mobon. Sem contar que nos outros dois eventos, além de contar com tais agentes, o público pôde se encontrar com um dos fundadores do Mobon, João Resende.

${ }^{51}$ Uma das formas encontradas para se situar (Geertz, 2008b) e estabelecer relações de comunicação com os agentes da CEBs foi tocar triângulo e "fazer animação" em alguns eventos.

${ }^{52}$ Cf. Cardoso de Oliveira (1996).
} 
melhor analisada (Figura 1). Na época, essa era apenas mais uma das tarefas no meio do emaranhando de ações realizadas após se chegar de uma atividade de campo, com o intuito de posteriormente servir de lembrança de todo o processo vivido em cada evento. Todavia, no momento do "tratamento dos dados", eis que, em busca de respostas para algumas questões (Como o "método do Mobon" foi difundido, isto é, como circulou pelas várias localidades de Minas Gerais? Como ele foi reproduzido de geração em geração? Como esse método foi incorporado, reapropriado e ressignificado por cada geração e em diferentes espaços eclesiais e, sobretudo, em situações de formação do campo político?), as coisas passaram a falar.

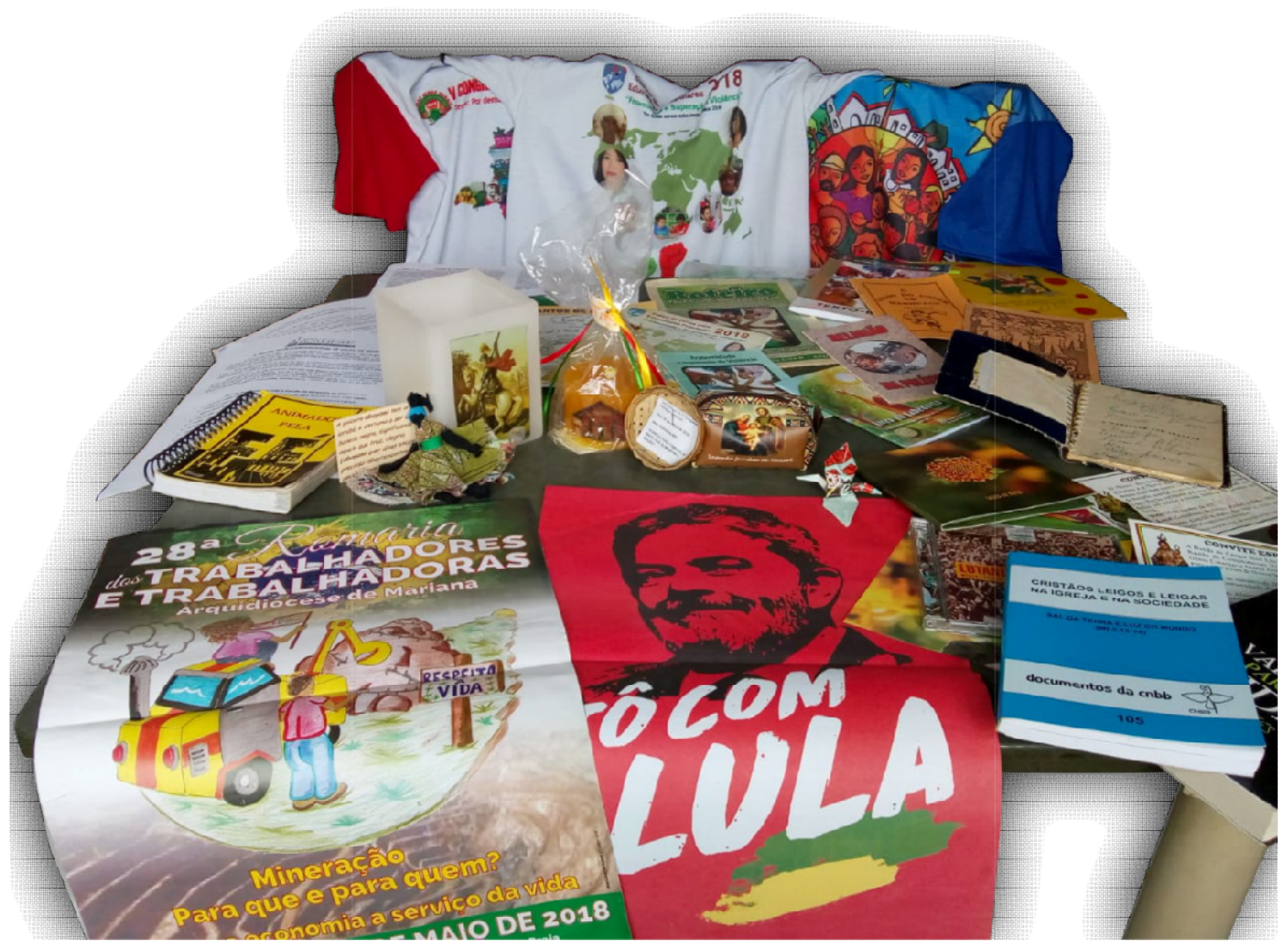

Figura 1. Alguns "materiais adquiridos" durante o trabalho de campo (camisas, CDs, livros, cartazes, cancioneiros, roteiros, souvenirs, etc.). Foto: Acervo próprio.

A partir dos efeitos de conhecimento gerados pela observação em campo, somados ao conhecimento gestado pelo retorno aos diálogos (gravados e anotados) com os agentes da cultura e pela afetação (Fravet-Saada, 2005) proporcionada pelo fato de manipular $^{53}$ tais coisas, chegou-se provisoriamente a quatro classes de coisas que circundam a prática militante

\footnotetext{
${ }^{53}$ No sentido de “'mexer com as mãos', 'manusear', numa aproximação à noção de técnica manual” (Menezes, 2017, p.2).
} 
católico-política ${ }^{54}$ dos agentes das CEBs com os quais mantem-se contato - queremos dizer, tanto aqueles que atuam no âmbito das comunidades como "leigos/as", quanto daqueles que são "filhos/as de CEBs" e atuam em outros campos, como o político (nas esferas sindicais, em Fóruns de participação, ONGs e movimentos sociais, por exemplo). São elas: (i) as coisasque-atuam-como-segunda-pele ${ }^{55}$; (ii) as coisas-que-atuam-como-compósitos-de-cenários; (iii) as coisas-de-informação/formação-sistematizada e iv) as coisas-de-registro-escritoda-memória.

No primeiro caso, são aqueles materiais que estão sobre a pele. Geralmente, camisas, bonés, embornais, cordões, amuletos, guias, fitas de amarrar nos braços, anéis (de tucum, por exemplo) entre outros, que atuam como "fardas", como se referiu um agente da cultura em uma conversa sobre as "camisas do movimento" ${ }^{~}$. Compõem uma indumentária "da luta" que distingue uma pessoa da outra, ao mesmo tempo em que a aproxima de um universo identitário comum de um "novo jeito de ser Igreja". Como refletiu Farinhada, educador e artista popular "filho de CEBs" que atua como animador, articulador e militante em diversas frentes, como no movimento negro, agroecológico e de cultura popular, são materiais que

\footnotetext{
${ }^{54}$ Caracterizamos a prática militante com a qual se teve contato como católico-política, pela maior recorrência de pessoas que "fazem a luta" se considerarem católicas. Mas, não se pode deixar de dizer, que o termo não dá conta de toda uma diversidade de expressões militantes encontradas em campo. Percebeu-se que a prática militante de agentes das CEBs se expressa também sob a lógica de uma práxis afroameríndia-política, que, ora dialoga com a prática católico-política (caso, por exemplo, das performances desempenhadas pela Pastoral Negra, pelo grupo das Terapias Tradicionais de Caratinga entre outras), ora lhe apresenta críticas (como em algumas performances e discursos realizados por indígenas, quilombolas, população de terreiros de umbanda e candomblé, durante alguns eventos que o pesquisador participou).

${ }^{55}$ Trata-se de uma classificação, construída a partir do conceito de roupa para montanha, conhecida no Brasil como "segunda pele" (ou Base Layer). Como definido no site da Solo ${ }^{\circledR}$, empresa especializada em vestuário para montanhismo e camping, "A segunda pele é uma peça de roupa feita com tecido leve e fino, cujo objetivo principal é aquecer o corpo. Ela recebe essa nomenclatura porque deve ficar em contato com a pele, garantindo o máximo de aquecimento. Como o seu tecido é fino e fica bem confortável, dá a ideia de uma segunda camada de pele", ou, ainda, como complementa a definição dada pelo site "Alta Montanha", "são roupas que são vestidas diretamente sobre o corpo, daí seu nome, elas são finas e coladas à pele”. Com isso, é possível realizar aproximações com o quer se quer definir por materiais segunda pele, ou seja, são aqueles que ficam colados ao corpo, em que objeto e pessoa são entidades dissociadas ou dissociáveis a partir de uma razão (Menezes, 2017). Atuam como "farda" que aquece, protege e identifica as pessoas. Em outras palavras, são materiais que situam a pessoa no mundo, entendido como uma rede de símbolos em constante transação passíveis de múltiplas interpretações.

${ }^{56}$ No dia 1\%11/2018 durante uma conversa descontraída na casa de um casal, na Diocese de Caratinga, o pesquisador ao reparar que os donos da casa e ele próprio estavam com camisas "do movimento" de eventos que participaram juntos (o pesquisador estava com uma camisa da $130^{\mathrm{a}}$ Festa de Nossa Senhora do Rosário em Airões, que aconteceu em Paula Candido; o anfitrião estava com a camisa do Curso de Férias para Educadores Populares 2018, acontecido em Caratinga; e sua esposa estava com a camisa das CEBs, que todos foram presenteados durante o $7^{\circ}$ Encontro de Formação de Leigos e Leigas da Diocese de Itabira-Coronel Fabriciano, acontecido em Ipatinga), o educador popular, "fillho de CEBs" disse que "a gente só anda de farda", se referindo que a maior parte das camisas que tem são "do movimento". Não é gratuito o termo (farda), ele remete a vestimenta militar e nos transporta para um ambiente de combate, "de luta", próprio de um catolicismo dos reafiliados, de alta intensidade característico das CEBs (Teixeira, 2009), combativo e que faz a opção de "ser fermento" para mudar a realidade do "povo oprimido".
} 
demarcam uma distinção. Como disse em sua apresentação durante um encontro de celebração da "Esperança com músicas da caminhada", no dia 05/01/2018:

(...) o povo começou a me chamar de PJ [por causa de sua atuação na década de 1990 em defesa do Rio São Gonçalo, quando fazia parte da Pastoral da Juventude, em Espera Feliz] e é muito comum muitas lideranças ainda me chama de PJ porque tinha referência da briga que eu comprava. Um embornalzinho da PJ, camisa da PJ, todo mundo falava, esse cara só tem uma camisa, né... Lavava e vestia de novo, né. E era aquelas camisas, "Ouço eco da vida", "Juventude caminho aberto", "Juventude e cidadania", "Latinos americanos, por que não?"... (Farinhada, 42 anos, Manhumirim, transcrição de áudio 05/01/2018, grifo nosso).

No segundo caso, tratam-se de produtos e objetos, como frutas, legumes, tubérculos, raízes, imagens de santo, a Bíblia Sagrada aberta, as ferramentas de trabalho (geralmente a foice, a enxada e/ou facão), bandeiras, estandartes, pano de chita ou chitão, cabaças, ervas medicinais, velas, fumaça, instrumentos musicais, sementes, etc. que compõem a simbolização de plenárias, celebrações, reuniões, congressos, rodas de conversa, e atualmente, em decorrência da aproximação dos agentes da cultura investigada com a Universidade, as instalações artístico-pedagógicas (I.A.P.) ${ }^{57}$ (Figuras 2, 3 e 4).

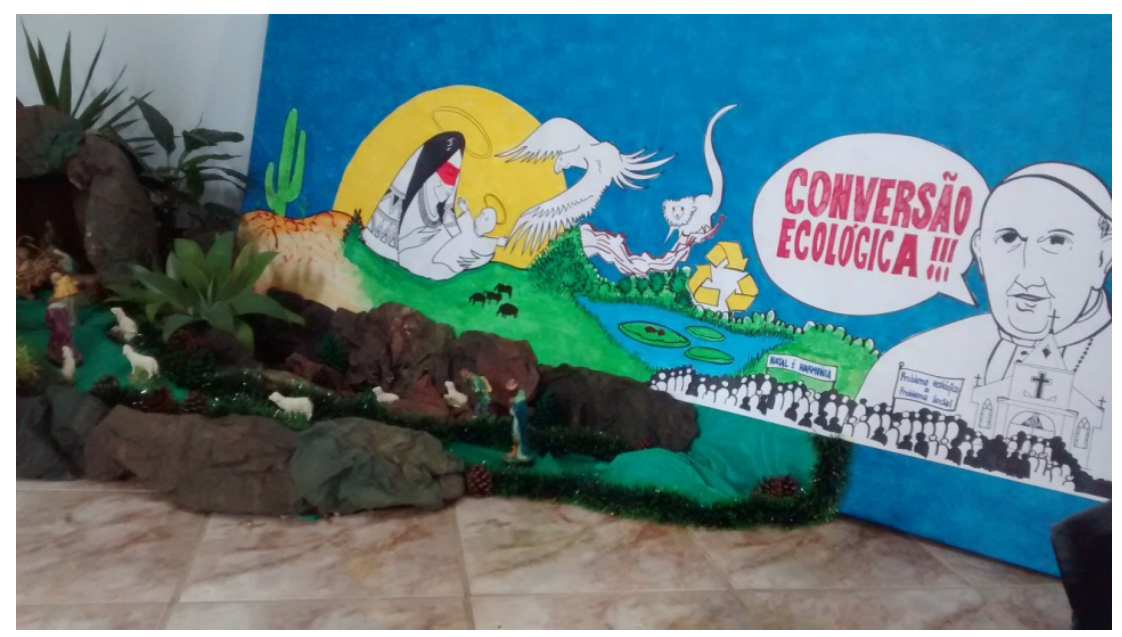

Figura 2. Presépio de Natal (2017), Comunidade Nossa Senhora Aparecida, Manhumirim. Foto: acervo próprio.

\footnotetext{
${ }^{57}$ As I.A.P.s são um mote metodológico criativo e dinamizador de diálogos e socializações que se fundamenta na criação de ambiências artístico-pedagógicas compostas por elementos da realidade, deslocados e exagerados, instalados num local fixo e que são observados pelos participantes, que provoquem os sentidos para determinado tema e que serão o ponto de partida para a discussão de sentires e saberes sobre o que podem representar (Alvim, 2013).
} 


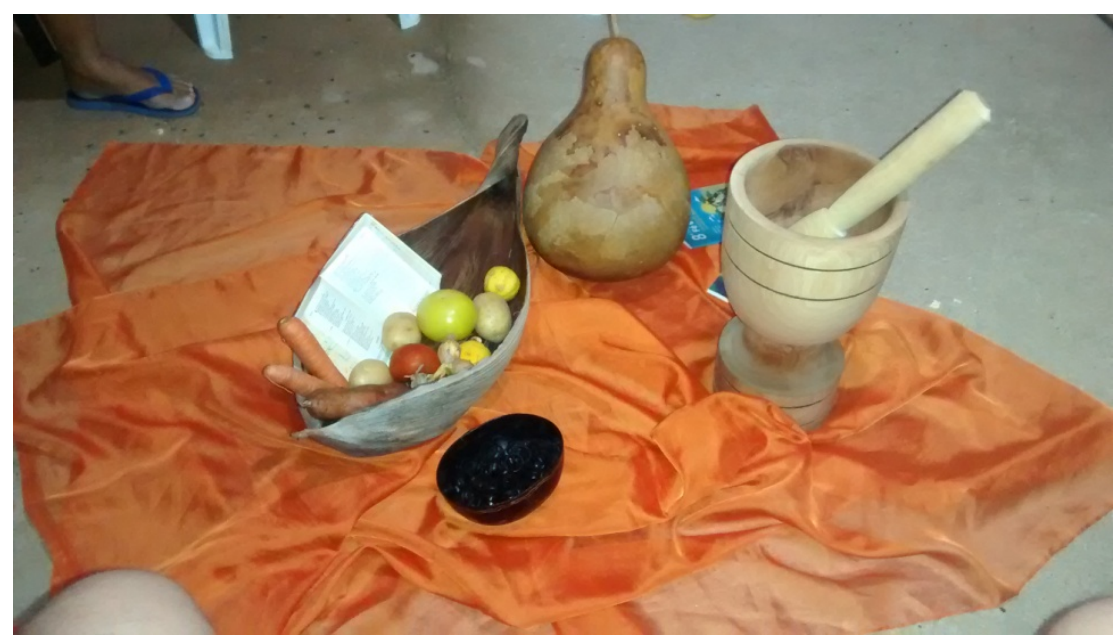

Figura 3. Cenário do Encontro para celebrar a Esperança com Músicas da Caminhada, Manhumirim, 05/01/2018. Foto: acervo próprio.

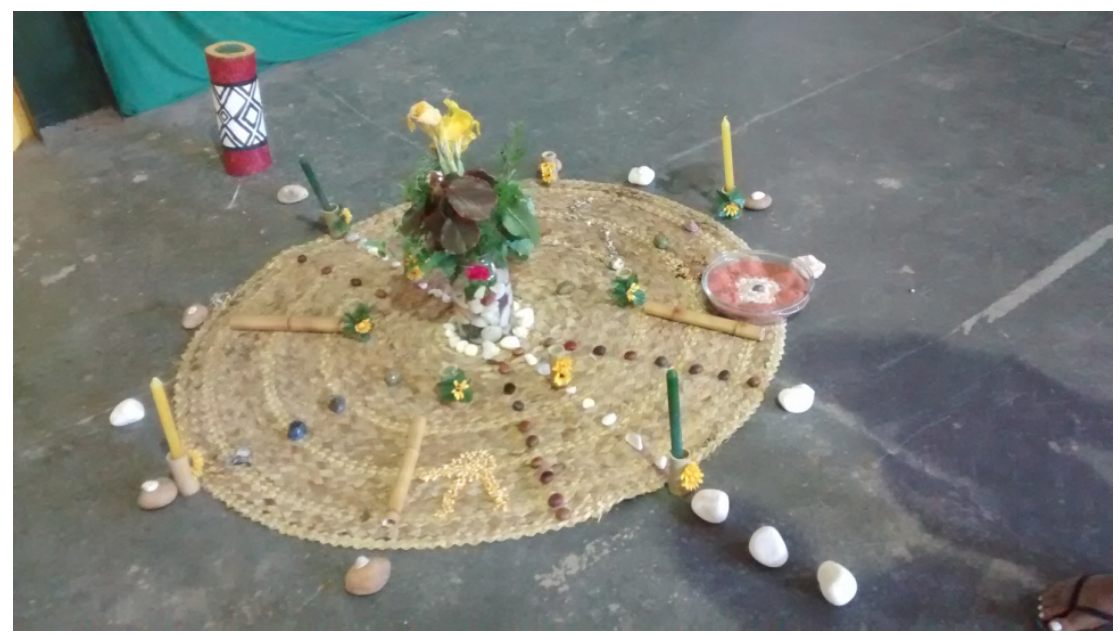

Figura 4. Cenário montado por integrantes da Majú Escola de Terapias Holísticas de Caratinga, à frente do palco, durante o Curso de Férias para Educadores Populares, Caratinga, 10/01/2018. Foto: acervo próprio.

Como compósitos de cenários, esses materiais possibilitam a representação de uma estrutura de sentimento em que, grosso modo, expressam-se o pensamento tal como sentido e o sentimento tal como pensado (Williams, 1979a apud Barbosa, 2005). Assim, de forma sui generis há "uma profusão de criações nas liturgias e nos momentos coletivos de se juntar o vivido e o pensado" (Pessoa, 2016, p.85). Nas duas primeiras classes de coisas, os materiais funcionam como "símbolos mobilizadores partilhados" (Oliveira, 2012, p.13).

No terceiro caso, tratam-se de livretos de curso, cancioneiros, livros, textos-base, documentos da igreja, cartilhas, roteiros, cadernos do participante, CDs, DVDs, jornais, convites para eventos, flyers, marca páginas, etc. que são utilizados para informar e divulgar eventos (cursos, novenas, festas de devoção a santos, romarias etc.) e/ou para o estudo pelos agentes de CEBs. E, por último, a quarta classe de coisas é composta por cadernos, blocos, 
livretos de curso e agendas onde os cursistas, "leigos" e "filhos de CEBs", registram por escrito e/ou utilizando desenhos o que é conversado durante os cursos ou onde se copia o que escreveram no quadro ou exibiram no projetor os ministrantes das formações ${ }^{58}$.

Em linhas gerais, em todas as classes de coisas mencionadas o simbólico é passível de várias interpretações (as coisas são polissêmicas), o que coloca sempre em jogo uma tensão interpretativa entre pontos de vistas antagônicos ${ }^{59}$; cada umas das coisas possuem marcada em sua materialidade estórias (causos) que se conectam à História de longa duração do modo de ser CEBs; essas coisas (como as pessoas e as ideias) circulam, e ao fazerem, encontram diversos territórios de saberes para sua expressão ${ }^{60}$, podendo ser coletivizada ou particularizada pelo grupo que a toma “de empréstimo" (Wagner, 2010) ${ }^{61}$. Esse processo potencializa a pluralidade de maneiras de ser católico. Isto é, ao terem seu conteúdo semântico apropriado (ou não) espaço-temporalmente e geracionalmente, tenciona-se a tradição católica e se gera espaço para (re)inventá-la.

Enfim, essas coisas estiveram, direta ou indiretamente, presentes em diferentes espaços e tempos por onde passamos. Por onde circulam, são consideradas (em seus diversos significantes) por muitas pessoas. Elas estão sempre, de alguma maneira, presentes nos espaços de formação para a luta. Assim, incorporadas, são símbolos que povoam o imaginário dos agentes da cultura e (re)enquadra-lhes a suas formas de comunicar, perpetuar e desenvolver seu conhecimento e suas atividades em relação à vida (Geertz, 2008a).

\footnotetext{
${ }^{58}$ Para acesso a um exemplo representativo das coisas-de-registro-escrito-da-memória, vale a pena conferir os Cadernos de Dona Cora Furtado, disponíveis em: <http://nmspp.net.br/dona cora >. Acesso em: 19 nov. 2018.

${ }^{59}$ A título de exemplo, ilustra essa tensão interpretativa os recentes casos de violências envolvendo coisas "da luta" ou, nos casos mais graves, as agressões a pessoas portadoras dessas coisas. O que para um certo grupo possui um significado positivo, para outros (externos ao sistema de pensamento), pode se manifestar como negativo. Durante as eleições de 2018, arrolaram uma série de episódios onde esse processo de disputa de interpretações se expressou. Para ficarmos com alguns casos, podemos citar as agressões sofridas por um professor de geografia e seu irmão, que foram agredidos em Belém/PA pelo fato de o primeiro usar uma camisa em que se encontrava escrito "Ogum" e o segundo por portar um adesivo da campanha de Haddad, a época candidato pelo Partido dos Trabalhadores (PT) à presidência. Pode-se citar também a agressão a um estudante por eleitores de Bolsonaro sob a justificativa de que foi o uso de um boné do Movimento dos Trabalhadores Sem Terra (MST) pelo estudante que motivou a ação; o caso da destruição da placa de rua que homenageava Marielle Franco, vereadora pelo Partido Socialismo e Liberdade (PSOL), defensora do Direitos Humanos que foi brutalmente assassinada em março de 2018 no Rio de Janeiro; além do recentes casos de agressões verbais sofridas por bispos da Conferência Nacional dos Bispos do Brasil (CNBB), acusados de serem "comunistas" e "abortistas".

${ }^{60}$ Para a discussão sobre uma cartografia dos objetos, cf. Bitter (2013).

${ }^{61}$ Como escreve Wagner, uma invenção (coisa, valor, técnica etc.) ao entrar em contato com uma "cultura alheia" ou uma "novidade cultural”, duas são as possibilidades, “(...) enquanto certas realidades assimilariam e simbolizariam a invenção coletivizado- $a$, utilizando-a de modo a neutralizar as tensões derivadas da manifestação de certos conjuntos de motivações, outros contextos valer-se-iam do novo para particularizar os vetores dessas tensões, contrastando interesses, atores, ações e formas de observar o mundo" (Carlos, 2012, p.339). Dito de outro modo, o contexto simbólico pode acolher as invenções imaginadas - entendidas, após leitura de Barth (2000), como sinais e signos manifestos e/ou orientações valorativas básicas -, incorporando-as "(...) de modo a reafirmar o que já preconiza a tradição, transformando o novo elemento em convenção" (Carlos, 2012, p.339), como também, pode negar tais invenções.
} 


\section{Considerações Finais}

Como ficou evidenciado por um breve texto programático, "Política e religião, objetos e pessoas não são entidades dissociadas ou dissociáveis a partir de uma razão única" (Menezes, 2017, p.14). Assim, as coisas que tivemos contato, suas maneiras de serem apropriadas e de comporem a performance são inventadas e reinventadas situacionalmente, localmente e geracionalmente. As coisas vão e vem como as pessoas que fazem o movimento "caminhando", ganham forma nas mãos dos "leigos", "leigas" e "filhos de CEBs", fomentam conversas e situações de interação.

Assim, por um "jogo de escala", elas "acabam funcionando como signos, emblemas ou estigmas e, também, como poderes" (Bourdieu, 1996, p.108), que nos fornecem evidências pertinentes para uma investigação efetiva sobre as situações sociais e comunicacionais (em seu significado mais amplo) estabelecidas no interior do sistema de aprendizagem do Mobon.

Esses elementos são constituintes da história. Atuam presentificando memórias, valores e, em eterna ressignificação enquanto circulam, funcionam como compósitos de uma identidade militante católica (em sua dimensão ecumênica e inter-religiosa) em toda a sua amplitude de significados e expressões. Esses objetos simbólicos são mananciais ético, poético e estético para a formação das pessoas.

$\mathrm{Na}$ certeza de que o que foi exposto aqui constitui-se uma discussão preliminar que carece de maiores investigações, para a política de conhecimento que se quer desvelar na pesquisa etnográfica em andamento, sobre grupos de agentes de CEBs formados direta ou indiretamente pelo Mobon, colocam-se algumas questões: Quais processos de alquimia social estão sendo produzidos na manipulação dessas coisas? Como essas coisas apontadas, que não são as únicas, convivem com a era da cibercultura? Quais são suas potencialidades formativas para a geração imersa no tempo das telas? Que outras coisas precisam ser consideradas para um estudo efetivo do fenômeno social (e cultural) total que propomos investigar?

À guisa de conclusão, espera-se que este texto possa contribuir para estimular outras pesquisas e o aprofundamento do tema da relação entre coisas e pessoas, municiando pesquisadores/as com mais uma espécie de dados sobre o catolicismo, as CEBs e suas diversas maneiras de "ser Igreja". 


\section{Referências bibliográficas}

ALVIM, Mayara Helena. Instalações pedagógicas: experimentos de um conceito em construção. 2013. 41 f. Monografia (graduação em Dança) - Departamento de Artes e Humanidades, Universidade Federal de Viçosa, Viçosa. 2013.

APPADURAI, Arjun. "Introdução: mercadorias e a política de valor". In: A vida social das coisas: as mercadorias sob uma perspectiva cultural. Niterói: Editora da UFF, 2008.

ARAÚJO, Ricardo Torri de. O movimento da Boa Nova. Belo Horizonte: Editora O Lutador, 1999.

BARBOSA, Willer Araujo. Cultura Puri e educação popular no município de Araponga, Minas Gerais: Duzentos anos de solidão em defesa da vida e do meio ambiente. 2005. 236 f. Tese (doutorado em Educação) - Programa de Pós-Graduação em Educação, Universidade Federal de Santa Catarina, Florianópolis. 2005.

BAUMAN, R.; BRIGGS, C. "Poética e Performance como perspectivas críticas sobre a linguagem e a vida social". Ilha, Revista de Antropologia, 2006, p.185-229.

BITTER, Daniel. "Cultura popular em trânsito: circulação e estetização de práticas performativas e objetos rituais entre folias de reis". In: REINHEIMER, Patrícia \& SANT'ANNA, Sabrina Parracho. (Org.). Manifestações artísticas e ciências sociais: reflexões sobre arte e cultura material. Rio de Janeiro: Folha Seca, 2013.

BOURDIEU, Pierre. A Distincão: crítica social do julgamento. São Paulo: Edusp; Porto Alegre, RS: Zouk, 2007, p.162-211.

BOURDIEU, Pierre. Linguagem e poder simbólico. In:

A economia das trocas

linguísticas. São Paulo: EDUSP, 1996, p.81-126.

BRANDÃO, Carlos Rodrigues. O afeto da terra. Imaginários, sensibilidades e motivações de relacionamentos com a natureza e o meio ambiente entre agricultores e criadores sitiantes do bairro dos Pretos, nas encostas paulistas da serra da Mantiqueira, em Joanópolis. Campinas: Editora da Unicamp, 1999.

CARDOSO DE OLIVEIRA, R. O trabalho do antropólogo: olhar, ouvir, escrever. Revista de Antropologia (USP), vol. 39, nº 1, São Paulo, 1996, p.13-37.

CARlOS, Daniel Pícaro. WAGNER, Roy. A invenção da cultura. São Paulo, Cosac Naify, 2010. 256 p. 2 Disponível em: $<$ www.revistas.usp.br/cadernosdecampo/article/download/53937/57881>. Acesso em: 06 nov. 2016.

DAWSEY, J.C. “O teatro dos 'bóias-frias': repensando a antropologia da performance. Horizontes Antropológicos, Porto Alegre, ano 11, n. 24, p. 15-34, jul./dez. 2005.

DOUGLAS, Mary \& ISHERWOOD, Baron (Org.). O mundo dos bens. Para uma antropologia do consumo. Rio de Janeiro: Editora UFRJ, 2004.

FAVRET-SAADA, Jeanne. Ser afetado. Cadernos de Campo, São Paulo, n. 13, ano 14, p. 155-161, 2005.

GEERTZ, Clifford. "A Religião como Sistema Cultural”. In:

A Interpretação das

Culturas. Rio de Janeiro: Ed. LTC, 2008a.

GEERTZ, Clifford. "Uma Descrição Densa: Por uma Teoria Interpretativa da Cultura". In: A Interpretação das Culturas. Rio de Janeiro: LTC, 2008b.

GINZBURG, Carlo. "Sinais: raízes de um paradigma indiciário". In: Mitos, emblemas, sinais: Morfologia e História. São Paulo: Companhia das Letras, 1990.

INGOLD, Tim. Trazendo as Coisas de Volta à Vida: Emaranhados Criativos num Mundo de Materiais”. Horizontes Antropológicos 18 (37): 25-44, 2012. 
KOPYTOFF, Igor. "A biografia cultural das coisas: a mercantilização como processo". In: APPADURAI, Arjun. A vida social das coisas: as mercadorias sob uma perspectiva cultural. Niterói: Editora da UFF, 2008.

KUSCHNIR, K. A antropologia pelo desenho: experiências visuais e etnográficas. Cadernos de Arte e Antropologia, v. 5, n. 2, p. 5-13, 2016.

LIMA, Raquel dos Santos Sousa. Sobre a representação nas imagens dos santos católicos: considerações a partir de um estudo sobre a devoção à Santa Rita. Religião \& Sociedade, v.35, p.139-163, 2015.

MALINOWSKI, Bronislaw. Argonautas do Pacífico Ocidental. Um relato do empreendimento e da aventura dos nativos nos arquipélagos da Nova Guiné Melanésia. São Paulo: Abril Cultural, 1984.

MARCUS, George. Ethnography in/of the world system: the emergence of multi-sited ethnography. Annual Review of Anthropology, v. 24, 1995, p. 95-117.

MAUSS, Marcel. "Ensaio sobre a dádiva. Forma e razão da troca nas sociedades arcaicas". In: Sociologia e antropologia. São Paulo: Cosac \& Naify, 2003, p.185-318.

MENEZES, Renata de Castro. A dinâmica do sagrado: rituais, sociabilidade e santidade num convento do Rio de Janeiro. Rio de Janeiro: Relume Dumará: Núcleo de Antropologia da Política/UFRJ, 2004.

Celebrando São Besso ou o que Robert Hertz e a Escola Francesa de Sociologia têm a nos dizer sobre festas, rituais e simbolismo. Religião \& Sociedade, p. 179-199, 2009.

A imagem sagrada na era da reprodutibilidade técnica: sobre santinhos. Horizontes Antropológicos, Porto Alegre, ano 17, n. 36, p. 43-65, jul./dez. 2011.

"Reflexões sobre a imagem sagrada a partir do "Cristo de Borja"". In: REINHEIMER, Patrícia \& SANT'ANNA, Sabrina Parracho. (Org.). Manifestações artísticas e ciências sociais: reflexões sobre arte e cultura material. Rio de Janeiro: Folha Seca, 2013.

Santos, vadias e fetos. Manipulações políticas de imagens religiosas no Brasil contemporâneo. Ponto Urbe, n.20, p.1-20, 2017.

OLIVEIRA, Fabrício Roberto Costa. Religião, política e comunidade: emergência e politização do Movimento da Boa Nova. 2012. 246f. Tese (doutorado em Ciências Sociais em Desenvolvimento, Agricultura e Sociedade) - Programa de Pós-Graduação em Desenvolvimento, Agricultura e Sociedade, Universidade Federal Rural do Rio de Janeiro, rio de Janeiro. 2012.

PEIRANO, M. "Rituais como estratégia analítica e abordagem etnográfica"; "A análise antropológica dos rituais". In:

O dito e o feito. Ensaios de Antropologia dos rituais. Rio de Janeiro: Relume Dumará, 2001, p. 7-40.

PESSOA, Jadir de Morais. "Educação popular na pastoral da terra". In: COMISSÃO NACIONAL DE FORMAÇÃO DA CPT. CPT - 40 anos de fé, rebeldia e esperança. São Paulo: Expressão Popular, 2016.

RINALDI, Alessandra et al. "Introdução". In: REINHEIMER, Patrícia \& SANT'ANNA, Sabrina Parracho. (Org.). Manifestações artísticas e ciências sociais: reflexões sobre arte e cultura material. Rio de Janeiro: Folha Seca, 2013.

SCHECHNER, R. "Uma tarde com Richard Schechner" (entrevista com Ana Bigotte Vieira e Ricardo Seiça Salgado). In: LIGIÉRO, Z (Org.). Performance e Antropologia de Richard Schechner. Rio de Janeiro: Mauad Editora, 2012, p.21-45.

SILVA, R. A. Entre 'artes' e 'ciência': a noção de performance e drama no campo das ciências sociais. Horizontes Antropológicos, Porto Alegre, ano 11, n. 24, p. 35-65, jul./dez. 2005.

TAYLOR, Diana. "Traduzindo Performance". In: DAWSEY, J. et al. Antropologia e Performance. São Paulo: Terceiro Nome, 2013, p. 9-16. 
TEIXEIRA, Faustino. "Faces do catolicismo brasileiro contemporâneo". In: TEIXEIRA, Faustino; MENEZES, Renata (Org). Catolicismo plural: Dinâmicas contemporâneas. Petrópolis, RJ: Vozes, 2009.

TEIXEIRA, Faustino; MENEZES, Renata. "Catolicismo plural: uma introdução". In:

(Org). Catolicismo plural: Dinâmicas contemporâneas. Petrópolis, RJ: Vozes, 2009.

TURNER, Victor. "Os símbolos no ritual Nembu". In:

Floresta de Símbolos: aspectos do ritual Ndembu. Trad. Paulo Gabriel Hilu da Rocha Pinto. Niterói: Editora da Universidade Federal Fluminense, 2005, p.49-82.

VALERI, V. "Festa". In: Enciclopédia Einaudi, v. 30: religião-rito. Lisboa: Imprensa Nacional-Casa da Moeda, 1994, p. 402-414.

VIVEIROS DE CASTRO, Eduardo. "Perspectivismo e multinaturalismo na América indígena”. In: _ A Inconstância da Alma Selvagem e Outros Ensaios de Antropologia. São Paulo: Cosac \& Naify, 2002.

WAGNER, Roy. "A presunção da cultura" e "A cultura como criatividade". In: . A Invenção da Cultura. São Paulo: Cosac \& Naify, 2010, p. 27-72. 